\title{
Perspectives of the Artemisia annua Dry Leaf Therapy (ALT) for Malaria and of its Re-Purposement as An Affordable Cure for Artemisinin- Treatable Illnesses
}

\author{
RICHA GOEL ${ }^{1}$, RAJ KUMARI ${ }^{2}$, VIJENDER SINGH ${ }^{3}$, RICHA PANDEY ${ }^{4}$, RENU KUMARI ${ }^{5}$, SUCHI \\ SRIVASTAVA $^{6}$ and SUSHIL KUMAR ${ }^{5,7, *}$ \\ ${ }^{1}$ Department of Pharmacognosy, KIET School of Pharmacy, Ghaziabad 201 206, India \\ ${ }^{2}$ Department of Pharmacognosy, ITS College of Pharmacy, Ghaziabad 201 206, India \\ ${ }^{3}$ School of Pharmacy, Sharda University, Greater Noida, Ghaziabad 201 306, India \\ ${ }^{4}$ Division of Natural Product Chemistry, CSIR-Indian Institute of Chemical Technology (IICT), Uppal \\ Road, Tarnaka, Hyderabad 500 001, India \\ ${ }^{5}$ National Institute of Plant Genome Research (NIPGR), Aruna Asaf Ali Marg, New Delhi 110 067, India \\ ${ }^{6}$ Division of Plant Microbe Interactions, CSIR-National Botanical Research Institute (NBRI), Lucknow \\ 226001 , India \\ ${ }^{7}$ SKA Institution for Research, Education and Development, 4/11 Sarv Priya Vihar, New Delhi 110016 , \\ India
}

(Received on 2 January 2018; Revised on 05 May 2018; Accepted on 06 May 2018)

\begin{abstract}
Malarial diseases continue to risk the lives of more than 3 billion people in 97 countries in the world, causing sickness in several million people and death to half a million patients. The preponderate malaria causing apicomplexan protozoan parasite species Plasmodium falciparum and Plasmodium vivax have become genetically resistant to most of the approved antimalarial drugs, including the artemisinin-based combination therapies (ACTs). At this time, there is a vigorous need to make enough efforts to meet the challenge of combating multi-drug resistant malaria by (a) speeding up the trials in progress on relatively more effective, new and mechanistically different antimalarial pharmaceuticals, (b) production of effective vaccines against falciparum and vivax malaria, (c) devising of new ways to use the presently available anti-malarials such as by using three-drugs ACTs and by using the different two-drug and three-drug ACTs sequentially, and (d) induction of Artemisia annua dry leaf therapy (ALT) of recent origin, but of ancient precedent, as an effective treatment for acute and complicated malaria. Here, a perspective type review is presented of the: pre-ALT antimalarial drugs, methodology of their usage and consequences of resistance development; safety, efficacy, affordability, quality maintenance and resilience to resistance development aspects of ALT; and possibilities of ALT re-purposement for treating many infectious-metabolic disorder related- and cancerous-diseases. In conclusion, an urgent need is emphasized for pilot studies and clinical trials on ALT to attest its deployment as anti-malarial and cure for diseases beyond malaria.
\end{abstract}

Keywords: Antimalarial Drug-Resistance; Antimalarial Pharmaceuticals; Auto-Immune Diseases; Cancers; Infectious Diseases; Non-Artemisinic Secondary Metabolites.

\section{Introduction}

Malaria, which results from the transmission of malarial parasite infection to humans by the bites of infected mosquitoes, is the deadliest infectious disease of tropical and sub-tropical climates. Malaria Eradication Scientific Alliance (MESA) has recently updated the research agenda for malaria elimination and eradication (malERA.2017). In recent years (such

*Author for Correspondence: E-mail: sushil2000_01@yahoo.co.in 
as 2015, 2016), 3.5 billion people in 97 countries were at risk of getting infected with malarial parasite(s) (Fig. 1). Actually, in each of these years, several hundred million humans got malarial infections and about half a million patients, preponderantly young children, elderly, and pregnant women, succumbed to the disease. In 2016, about $90 \%$ of malaria in Southeast-cum-South Asia region was contributed by India (World 2016 Malaria report). In approximately last ten years, since the introduction of artemisinin combination therapy (ACT) as the treatment of malaria and regulation of parasite transmission, at least ten countries have become largely malaria free. During this period, due to success in control of the disease causing parasite by chemotherapeutic treatments, such as ACT, prophylaxis, and control of mosquito attacks by use of pyrethroid insecticide impregnated bednets and indoor insect repellants (Landier et al., 2016; Dondrop et al. 2017; Sluydts et al., 2017), the loss of life from malaria has been halved. For the last 72 years, from the time chloroquine was introduced as a substitute/ alternative of quinine in malaria treatment, the disease has been contained by use of five classes of individual pharmaceuticals (aminoquinolones, aminoalcohols, antifolates, hydronapthoquinone and endoperoxides) and their combinations. However, malaraial parasites have developed genetic resistance against most (perhaps all) of the effective antimalarials and their combinations. Besides, the resistant parasites have become geographically widespread. The vector mosquitoes have also developed resistance to insecticides used to impregnate bednets. The new affordable antimalarial chemical compounds and vaccines undergoing tests and trials are thought to be atleast a decade away (Dondrop, 2017; White, 2017; Kazmin et al., 2017; Lopaticki et al. 2017; Sissoka et al., 2017; Nasamu et al., 2017; Bisland et al. 2018; Cowell et al. 2018; Kisalu et al. 2018). All these factors have posed a grave challenge for the control of malarial disease worldwide in coming years. Discussion is in progress on ways to increase the life span of currently available pharmaceuticals by employing them in alternate combinations, to resist the resistance power in the parasite and combat parasite transmission. At this time, when new effective and affordable malarial treatments are being eagerly

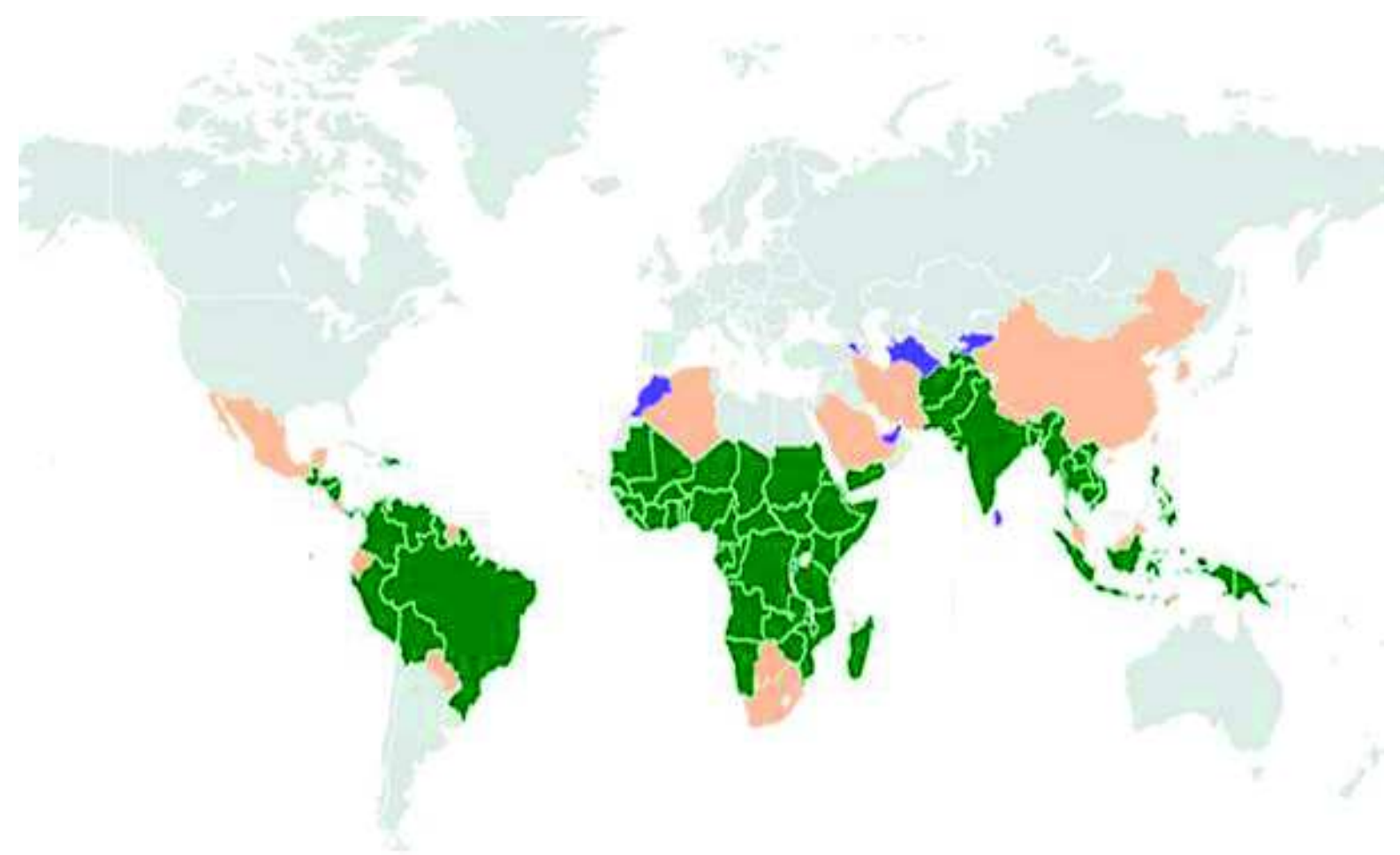

Fig. 1: World map of malaria endemic areas: the green coloured areas = transmission rate of malaria is high; peach coloured areas: relatively lower malaria transmission rate; indigo colored areas = recently became malaria free; slate coloured areas $=$ have been malaria free for long time (reproduced with requested permission: Rabinovich $\mathrm{R} N$ et al., Plos Med 14, e1002456) 
awaited, a botanical treatment that appears to clear (artemisinin) resistant malaria has been recently described. Daddy et al. (2017) have reported success in curing 18 cases of severe malaria by administering to the patients tablets made of dry leaves of Artemisia annua (the natural rich source of the pharmaceutical artemisinin) plants. This treatment called Artemisia annua dry leaf therapy (ALT) was found to have cured malaria caused by parasites resistant to the currently used antimalarials, including artemisinin derivatives (Fig. 2). Perspectives of this novel, highly promising and innovative development are discussed in this review.
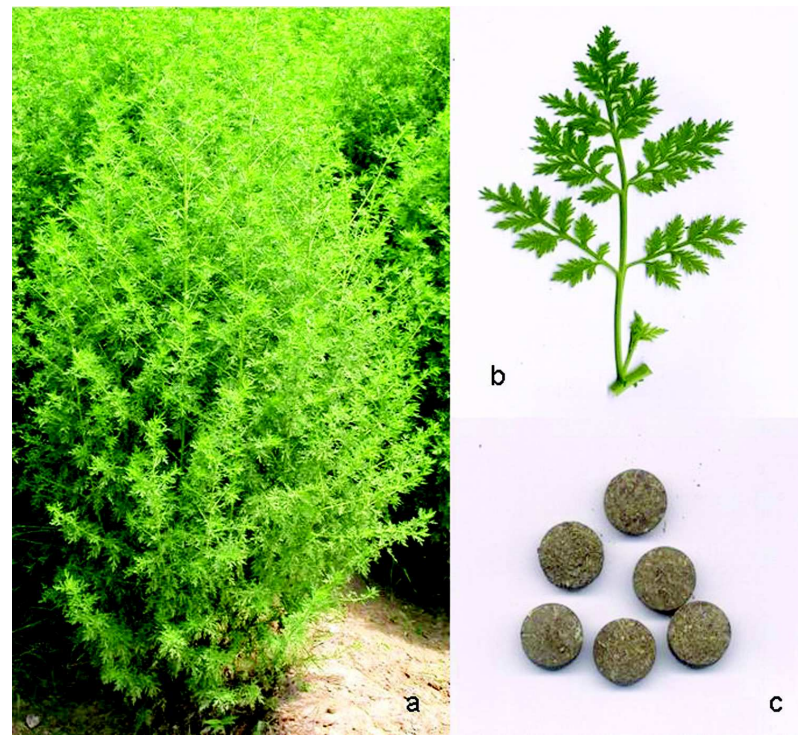

Fig. 2: ALT tablets made from dry Artemisia annua cv Sanjeevani leaves. a $=$ A plant of $A$. annua cv Sanjeevani at pre-flowering development stage; $b=A$. annua freshly harvested leaf; and $c=$ Tablets made by compressing the dried $A$. annua leaves

To delineate the importance of origin of ALT as a safe, efficacious and affordable antimalarial treatment, with multi-repurposing possibilities, this review (perspective) deals with several relevant subject matter areas. The first section defines characteristics of different species of malaria causing parasites, their vectors and endemicity alongwith several features of disease development. This is followed by chemical, biological and antimalarial properties of currently used (approved) antimalarials. Next are described the choices and methodologies of administration of antimalarials to adult, child, pregnant and lactating women patients of acute and complicated malarias. Nature of mutations that render parasites species resistant to individual and multiple antimalarial drugs and circumstances that allowed soft and hard sweeps of certain artemisinin resistant mutation(s) is discussed next. This is followed by a section on discussions taking place to devise strategies to combat drug resistant malaria, especially artemisinin resistance. The next section covers aspects about the origin, empirical basis and evidence on clinical efficacy of ALT. Following it are sections that discuss the quality maintenance and cost aspects of ALT. The final section brings into focus the possibilities of repurposing ALT as treatment for a variety of autoimmune, metabolic and cancerous diseases.

\section{Kinds of Malaria and Symptoms}

There are about 200 different unicellular eukaryotic apicomplexan obligate narrow host-range parasite species of the genus Plasmodium, transmitted by dipteran insect species, whose infection can cause various kinds of malarial diseases in a wide range of vertebrates. The five major species of Plasmodium that cause malaria in humans are falciparum (Pf), knowlesi $(\mathrm{Pk})$, malariae $(\mathrm{Pm})$, ovale $(\mathrm{Po})$ and vivax $(\mathrm{Pv})$. The important properties of these human malarial parasites are comparatively summarized (and the references concerned with this section are also given) in the Table 1. Among the human malarial parasites, $\mathrm{Pk}$ is known to be a zoonotic species whose infection in several species of macacque monkeys produces malaria-like symptoms. Recently, another zoonotic species- Plasmodium simium (Ps)- has been found to cause malaria in humans in the Atlantic Forest Area of Brazil. The natural hosts for Ps are monkeys of the genera Aloulta, Brachyteles, Cebus and Sapajus (Brasil et al., 2017).

The insect hosts of Plasmodium species are anopheline mosquitoes. Out of about 515 known species of Anopheles, approximately 70 are vectors of human malaria (Sinka et al., 2012). Each of Pf, $\mathrm{Pk}, \mathrm{Pm}, \mathrm{Po}, \mathrm{Pv}$ and Ps is transmitted to humans by several to many Anopheles species, in the geographical areas of their occurrence. The genomes ofhuman malarial Plasmodium species and of the major Anopheles vector species have been sequenced (Neafsy et al., 2015; Rufledge et al., 2017). The vector for Ps has been identified as Anopheles kertezsia cruzii (Brasil et al., 2017). Phylogenetically, 


\begin{tabular}{|c|c|c|c|c|c|c|c|c|}
\hline \multirow[t]{2}{*}{ S.No. } & \multirow[t]{2}{*}{ Characters } & & \multirow{2}{*}{$\begin{array}{l}\text { Plasmodium } \\
\text { falciparum }(P f)\end{array}$} & \multirow{2}{*}{$\begin{array}{l}\text { Plasmodium } \\
\text { vivax }(P v)\end{array}$} & \multicolumn{2}{|c|}{ Plasmodium ovale } & \multirow{2}{*}{$\begin{array}{l}\text { Plasmodium } \\
\text { malariae (Pm) }\end{array}$} & \multirow{2}{*}{$\begin{array}{l}\text { Plasmodium } \\
\text { knowlesi }(P k)\end{array}$} \\
\hline & & & & & curtisi (Poc) & wallikeri (Pow) & & \\
\hline 1 & $\begin{array}{l}\text { (A) Features of } \\
(n=14) \text { genome }\end{array}$ & Size (Mb) & 23.3 & 29.1 & 33.5 & 33.5 & 33.6 & 24.4 \\
\hline 2 & & Estimated gene number & 5355 & 6671 & 7165 & 6340 & 6559 & 5284 \\
\hline 3 & & $\mathrm{G}+\mathrm{C}$ content $(\%)$ & 19 & 40 & 29 & 29 & 24 & 39 \\
\hline 4 & & $\begin{array}{l}\text { Pre-erythrocytic growth in hepatocytes } \\
\text { (hepatic schizogony) (number of days }=\mathrm{d} \text { ) }\end{array}$ & $5-7$ & $6-9$ & $8-9$ & & $14-16$ & $6-9$ \\
\hline 5 & & $\begin{array}{l}\text { Whether relapse causing hypnozoites are } \\
\text { formed in liver? }\end{array}$ & No & Yes & Yes & & No & No \\
\hline 6 & & Incubation period (d) & $8-15$ & $10-21$ & $12-20$ & & $18-60$ & $10-12$ \\
\hline 7 & & $\begin{array}{l}\text { Fever cycle (erythrocytic schizogony) } \\
\text { (number of hours }=h \text { ) }\end{array}$ & Tertian (48) & Tertian (48) & Tertian (48) & & Quartan (72) & Quotidian (24) \\
\hline 8 & & Nature of red blood cells affected & $\begin{array}{l}\text { All types of } \\
\text { erythrocytes }\end{array}$ & Reticulocytes I & Reticulocytes & & $\begin{array}{l}\text { Mature } \\
\text { erythrocytes }\end{array}$ & $\begin{array}{l}\text { All kinds of } \\
\text { erythrocytes }\end{array}$ \\
\hline 9 & $\begin{array}{l}\text { (B) Features of life } \\
\text { cycle in human host }\end{array}$ & $\begin{array}{l}\text { Size of parasitaemia (number of parasites } \\
\text { per } \mu \mathrm{L} \text { of blood }\left(\times 10^{3}\right)\end{array}$ & $20-500$ & $20-50$ & $9-10$ & & $5-10$ & $0.5-10$ \\
\hline 10 & & $\begin{array}{l}\text { Whether cytoadherence of parasite causes } \\
\text { microvascular dysfunction? }\end{array}$ & Yes & \multicolumn{2}{|l|}{ Rarely (if at all) } & Rarely (if at all) & Rarely (if at all) & Yes \\
\hline 11 & & Whether severe malaria developes? & Yes & Yes & No & & No & Yes \\
\hline 12 & & Whether recrudescence occurs? & $\begin{array}{l}\text { Yes (when } \\
\text { treatment fails) }\end{array}$ & $\begin{array}{l}\text { Yes (when } \\
\text { treatment fails) }\end{array}$ & Rare & & $\begin{array}{l}\text { Yes (sometimes } \\
\text { after } 30 \text { to } 50 \text { y } \\
\text { from the primary } \\
\text { attack) }\end{array}$ & Yes \\
\hline 13 & & $\begin{array}{l}\text { Time of appearance of gametocytes } \\
\text { ( } d \text { after the start of parasitaemia) }\end{array}$ & $8-14$ & 0 & 0 & & 0 & Not known \\
\hline 14 & $\begin{array}{l}\text { (C) Features of life } \\
\text { cycle in mosquito } \\
\text { host }\end{array}$ & $\begin{array}{l}\text { Transmission causing Anopheles mosquito } \\
\text { vector species }\end{array}$ & $\begin{array}{l}\text { Many species } \\
(>70), \text { most } \\
\text { prominent are: } \\
\text { gambiae, } \\
\text { culicifacies and } \\
\text { stephensi }\end{array}$ & $\begin{array}{l}\text { Many species } \\
(>71), \text { most } \\
\text { prominent are: } \\
\text { aquasalis, } \\
\text { culicifacies, } \\
\text { stephensi, } \\
\text { darlingi and } \\
\text { dirus }\end{array}$ & \multicolumn{2}{|c|}{$\begin{array}{l}\text { Several species }(\sim 10) \text {, most } \\
\text { prominent are: funestus, } \\
\text { gambiae, stephensi, freeborni, } \\
\text { dirus, farauti and atroparvus }\end{array}$} & $\begin{array}{l}\text { Many species } \\
(>30), \text { most } \\
\text { prominent are: } \\
\text { culicifacies, } \\
\text { aconitus, } \\
\text { arabiensis, } \\
\text { atroparvus and } \\
\text { freeborni }\end{array}$ & $\begin{array}{l}\text { Several species } \\
\text { including: } \\
\text { craceus, hackeri, } \\
\text { latens and } \\
\text { bala-bacensis }\end{array}$ \\
\hline
\end{tabular}


Table 1: Contd ....

16 (D) Major geographical areas of prevalence

\begin{tabular}{|c|c|c|}
\hline $\begin{array}{l}\text { World-wide } \\
\text { tropical and } \\
\text { subtropical } \\
\text { areas (especially } \\
\text { in Africa, Asia } \\
\text { and Mediterr- } \\
\text { anean) }\end{array}$ & $\begin{array}{l}\text { World-wide } \\
\text { subtropical } \\
\text { areas } \\
\text { (especially in } \\
\text { Asia, Latin } \\
\text { America and } \\
\text { Africa) }\end{array}$ & $\begin{array}{l}\text { Tropical regions of Africa and } \\
\text { Asia and in Pacific islands, } \\
\text { sympatrically (subspecies) }\end{array}$ \\
\hline $\begin{array}{l}P f \text { is the prepon- } \\
\text { derant cause of } \\
\text { malaria. The } \\
\text { falciparum } \\
\text { malaria is the } \\
\text { deadliest and if } \\
\text { not treated timely } \\
\text { the acute (or un- } \\
\text { complicated) } \\
\text { malaria turns } \\
\text { into cerebral } \\
\text { (or complicated) } \\
\text { malaria }\end{array}$ & $\begin{array}{l}P v \text { can cause } \\
\text { severe disease } \\
\text { and death due } \\
\text { to splenome- } \\
\text { galy. The Duffy } \\
\text { blood group } \\
\text { deficient in } \\
\text { Africa when } \\
\text { infected are } \\
\text { often symptom }\end{array}$ & $\begin{array}{l}\text { In some cases relapse can occur } \\
\text { as late as } 4-5 \text { years from initial } \\
\text { inoculation } \\
\text { y } \\
\text { less }\end{array}$ \\
\hline
\end{tabular}

World-wide

tropical and

Southeast Asia

17

(E) Remarks

malaria 
distance-wise the parasite species are related to each other as follows: $\mathrm{Pf} \rightarrow \mathrm{Po} \rightarrow \mathrm{Pm} \rightarrow \mathrm{Pk}, \mathrm{Pv}$ and $\mathrm{Ps}$ (Hall, 2012; Brasil et al., 2017). In terms of the frequencies of malaria infections caused by them in humans, parasites fall in the following order: $\mathrm{Pf}>\mathrm{Pv}$ $>\mathrm{Po}, \mathrm{Pm}>\mathrm{Pk}>\mathrm{Ps}$. The malarias caused by Pf, Pv and Pk can be fatal if not treated. The Po and Pm caused malarias are less severe and generally not lethal. Pv, Ps and Po caused infections can remain dormant in the liver for up to many months. Pm infection can remain latent for years. The Duffy blood group deficient $(a c k r l=$ atypical chemokine receptor 1) humans (who are largely the inhabitants of West Africa) are resistant to infection by $\mathrm{Pv}$ and $\mathrm{Pk}$ because the parasites are unable to invade their $F y$ $a^{-} b^{-}$erythrocytes (de Carvalho and de Carvalho, 2011).

The Pf, Pv, Po, Pm, Pk and Ps malarias have differential distribution. $\mathrm{Pv}$ is the most widespread malaria; it is the major malaria causing parasite in subtropical areas of Asia, Americas and Africa. Nearly half of the malarial cases that occur outside of Africa are related to $\mathrm{Pv}$ infection. More dangerous than Pv malaria, Pf malaria is predominant in Africa, but also occurs in tropical regions of Asia and in Middle East. Pf malaria is responsible for $90 \%$ of malarial deaths in Africa. The distribution of Pm malaria is similar to that of Pf malaria except that it is much less frequent. Both Po and Pm are the cause of malaria in Pacific islands. There are two subspecies of Po called $P$. curtisi and $P$. wallekeri, both are cause of malaria in Africa and Asia, sympatrically. Together, Po and Pm account for about 10 million cases of new malaria each year. Malaria caused by $\mathrm{Pk}$ occurs largely in southeast- and south-Asia. The Ps malaria is limited to Brazil. In areas where frequency of occurrence of malarial infections is high, mixed infections of more than one Plasmodium species have been observed (Mayxay et al., 2004). Recently, a rare case of malaria caused by infection of Pf, Pv, Po and Pm has been reported from forest area in Central India (Krishna et al., 2017) which has high incidence of mixed infection.

Initial symptoms of malaria are often as nonspecific as one or more of the following type of sickness: fever, chills, sweating, fast heart rate, sore throat, cough, pneumonia, headache, muscular pain, joint pain, fatigue, difficulty in swallowing, hyper- salivation, jaundice, nausea, weakness, vomiting, constipation and enlargement of spleen. Laboratory diagnosis is essential to confirm malaria. The most reliable diagnosis is the detection of parasite-infected red blood cells through microscopic examination of thick and thin blood films. The rapid diagnostic tests (RDTs), based on detection of parasite antigens, can be used, but should not substitute for the needed microscopic tests (Kakkilaya, 2003). Once diagnosed, a confirmed malaria patient should immediately begin receiving the WHO prescribed treatment at the earliest.

The findings of microscopic test/s are helpful in classifying malaria as uncomplicated or severe. In cases of the non-complicated malaria, the parasitemia ( $\%$ of parasitized red blood cells) is lower than $2 \%$. If parasitemia is $10 \%$, the malarial patient is facing the severe form of disease. The symptoms of the severe malaria include high fever and one or more of the following conditions: renal impairment (dark urine and limited output) acidosis, hypoglycemia, spontaneous bleeding, breathing difficulties, severe anemia, prostration or coma. Young children and pregnant women are not only more vulnerable to malarial infection but also prone to developing severe malaria. Consequences of severe malaria in pregnant woman include miscarriage, stillbirth, premature birth and birth defects in neonates. Generally, all kinds of malaria cause bone loss due to chronic bone inflammation and adversely affect functioning of skeletal and heart muscles due to poor supply of nutrients and oxygen (Marrelli and Brotto, 2016; Lee et al., 2017). There occurs macrovascular dysfunction in $\mathrm{Pf}$ and $\mathrm{Pk}$ malaria due to adherence of infected cells to walls of blood vessels (White, 2017). The above kinds of deficits imposed by malaria, span of morbidity, possibility of death can all be checked by anti-malarial drug treatment which also aims to clear malarial parasites from the body of malarial patient such that malaria does not relapses and transmission to mosquitoes is blocked. Antimalarial drugs are also used as chemoprophylaxis, in mass drug administration campaigns to limit the spread of malaria in endemic areas, and to travelers visiting the malaria endemic areas.

\section{Currently Used Antimalarial Drugs}

The antimalarial drugs include; quinine, mefloquine, 
halofantrine and lumefantrine (aryl aminoalcohols); chloroquine, amodiaquine and piperaquine (4aminoquinolones); primaquine (8-aminoquinoline); pyronaridine (mannich base); atovaquone (napthaquinone); proguanil, pyrimethamine and sulfadoxine (antifolates); tetracycline, doxycycline and clindamycin (antibiotics); and artesunate, dihydroartemisinin and artemether (artemisinin derived endoperoxides). The Table 2 illustrates chemical structures, purpose and regimen of administration to malaria patients, biological effects on Plasmodium parasites and prescription properties. There are large inter-class and intra-class differences in the properties of the drugs. In vivo half-life of artemisinins is short ( 0.5 to few hours) as compared to that of lumefantrine, pyronaridine, pyrimethamine, sulfadoxine, piperaquine and chloroquine ( 3 to 60 days). Quinine and artemether are highly insoluble in water and are usable for parenteral application. Artemisinins are very fast acting drugs. Quinine, chloroquine, piperaquine and artemisinins are able to block transmission of parasites to mosquitoes. Primaquin too blocks transmission but also prevents $\mathrm{Pv}$ and Po malaria relapses. Quinine, mefloquine, lumefantrine, atovaquone and artemisinins do not allow multiplication of parasite in mosquitoes. Unlike proguanil, pyrimethamine, sulfadoxine and atovaquone target singular but different parasite functions, whereas artemisinin derivatives, chloroquine and quinine exemplify antimalarials which target multiple functions in the parasites.

To overcome deficiencies of individual chemotherapeutics and to slow down resistance development, anti-malarials are now used in combinations. The following combinatorial regimen have been recommended by WHO to cure various kinds of malaria (Table 2): chloroquine + primaquine (against $\mathrm{Po}$ and $\mathrm{Pv}$ malaria); quinine + tetracycline or clindamycin (against severe malaria); ACTs = artemether + lumefantrine or mefloquine, dihydroartemisinin + piperaquine, artesunate + pyronaridine or sulfadoxine + pyrimethamine or artesunate + amadiquine (against uncomplicated malarias, especially those caused by Pf). Primaquine or alternatively tafenoquine is given additionally to stop relapses and transmission; both are contraindicated for G6PD deficient patient (Table 3: Elmes et al. 2008; Graves et al., 2018). The tertian malaria caused by Ps is curable by chloroquine + primaquine treatment (Brasil et al., 2017). The combinations used for chemoprophylaxis in endemic areas are atavoquone + proguanil and proguanil + chloromycetin. For chemoprophylaxis mefloquin and doxycycline are also used preferably singly.

\section{Life Cycle Stages at which Plasmodia are Killed by the Anti-Malarial Drugs}

The Fig. 3 gives a diagramme of the life cycle stages of malarial parasites in human host and mosquito vector. Table 1 has quantitative data about parasite life cycle stages in all the five kinds of malaria. Life cycle stages at which the anti-malarials kill the parasites are identified in Table 2. The references from which information is described in this section, and summarized in Fig. 1, Table 1 and Table 2, was collated are given in the figures and tables.

The human host is inoculated with a small number $(>10)$ of sporozoites when an infected female mosquito bites to obtain a blood meal. Sporozoites reach liver through blood and lymphatic system and invade hepatocytes. There is no antimalarial drug that blocks this process. The parasites in liver cells develop into schizonts, wherein the parasite undergoes many divisions to produce thousands of merozoites. The liver tissue schizonts rupture and release the merozoites into the blood stream. There are no clinical symptoms of malarial illness all through this stage. Merozoites developing in their liver schizonts are killed by several antimalarial drugs: primaquine, atavoquone, proguanil, pyrimethamine, tetracycline, doxycycline and artemisinin derivatives (artemisinins). The liver stage is completed in about 5-9 days from inoculation, except that in Pm malaria, it takes up to 16 days. Some Pv and Po infected hepatocytes produce hypnozoites. These dormant parasites can get activated and cause relapsed malaria, any time up to 5 years. Hypnozoites are eliminated from the liver by the drug primaquine.

The merozoites released from liver invade red blood cells (RBCs). In the infected erythrocytes (RBCs), parasite forms schizonts in which it produces 16-32 merozoites per schizont. When these schizonts have ruptured and the released merozoites have invaded fresh erythrocytes, an erythrocytic-schizont cycle of parasite infection is completed. Only upon completion of 3-8 such cycles, the parasite density in blood reaches the pyrogenic level of $50 / \mu \mathrm{L}$. At this stage febrile paroxysm lasting 8-12 $\mathrm{h}$ appears. In this period the body temperature progressively rises and 


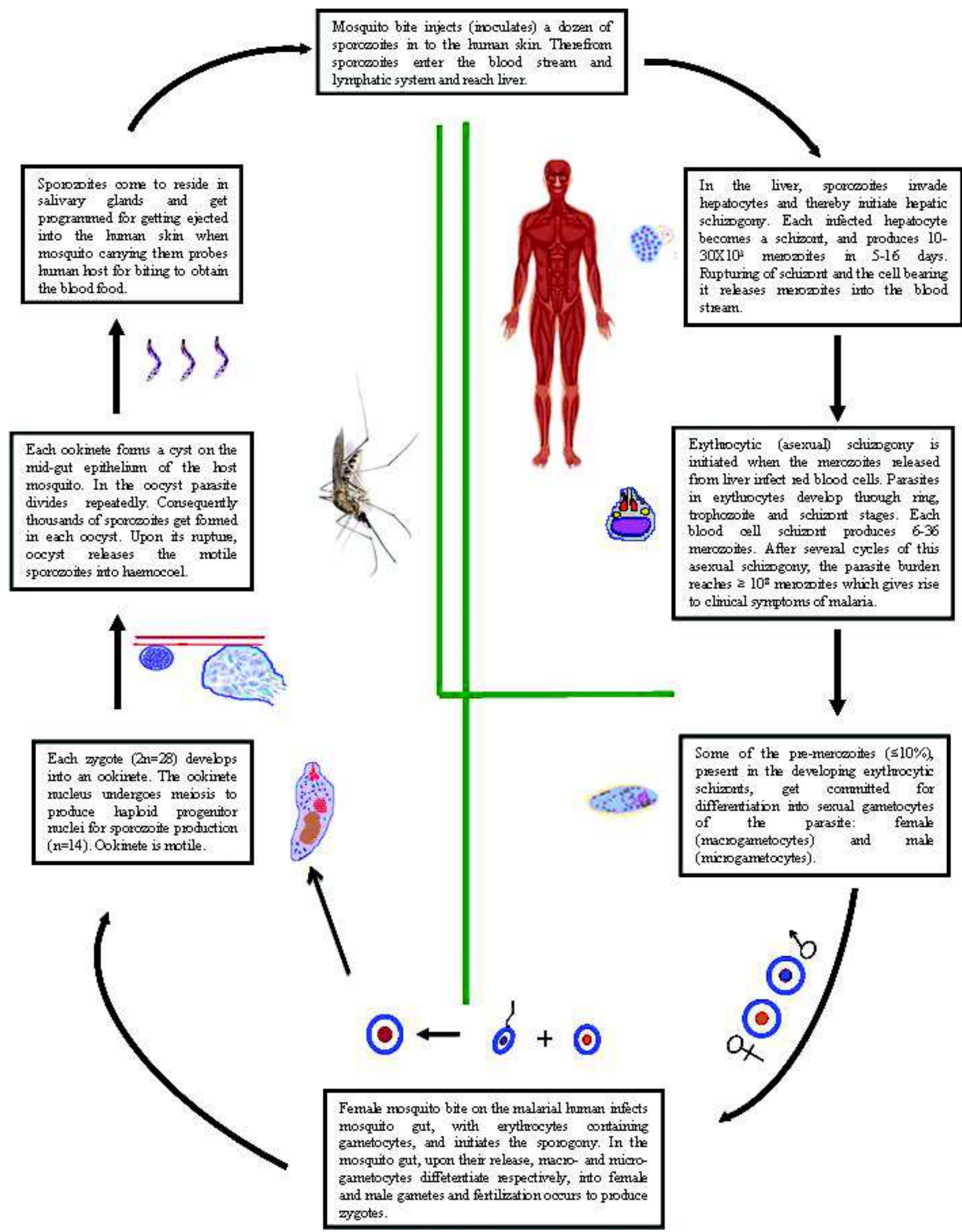

Fig. 3: Life cycle of the malaria causing parasites of Plasmodium species (adapted after Kumar et al. 2015). Five species of the unicellular protozoan Plasmodium that cause malaria in humans are falciparum, vivax, ovale, malariae and knowlesi. Genome sequences of all of these species are now known (Table 1). Humans get the transmitted malarial parasites 
when infected anopheline female mosquito bites them to obtain blood as its food. There are more than 500 species of Anopheles mosquito of which more than 60 serve as malaria vector. Genome sequences of the entire major malaria vector Anopheles species have been described (Neafsey et al., 2015). Life cycle of malarial Plasmodium species is complex and consists of several stages in each of the vertebrate and mosquito hosts. There are two asexual stages (in liver and red blood cells) and a sexual stage (in red blood cells) of Plasmodium life cycle in humans. (a) Hepatic schizogony: In this asexual phase the parasites inoculated into human host by mosquito, in the form of sporozoites, multiply asexually in liver parenchyma cells to produce a huge population of merozoites. Each sporozoite produces a few thousands of merozoites in schizonts. Not shown in the figure is an alternative pathway taken by parasites of $P$. vivax and $P$. ovale at this stage, wherein parasites enter a dormant phase to become hypnozoites. These latent parasites are the cause of relapse malarias, after several to many months from the initiation of infection as they reenter hepatic schizogony. (b) Erythrocytic schizogony: The liver produced merozoites infect red blood cells, wherein they pass into schizont stage after completion of ring and trophozoite stages. Each erythrocytic schizont produces many merozoites via asexual cell proliferation. Thus parasite load on the host increases enormously which leads to the appearance of clinical symptoms of malaria. (c) Gametocytogenesis: The pre-merozoites present in fraction of red blood cell schizonts get committed to sexual differentiation. Two types of gametocytes are formed: macro (female)- and micro-(male). The gametocytes are precursors of gametes. Gametocytes get ingested by the female mosquitoes that bite infected humans to obtain their blood meal. There are four stages of parasite development in the mosquito host. (d) Gametogenesis: Gametocytes ingested from human host enter into gametogenesis in the lumen of mosquito gut. Microgametocyte exits erythrocyte and differentiates into a female gamete. The microgametocyte upon exit from erythrocyte undergoes divisions there to produce eight flagellated male gametes by a process that has been called exflagellation. Fertilization involves fusion between a male gamete and a female gamete (both haploid like merozoites and gametocytes) to form zygote(s). (e) Ookineteization: One or more than one zygote is formed, depending on the number of female gametocytes ingested by the mosquito. Each zygote turns into a motile ookinete, during this processes its diploid nucleus undergoes meiosis to produce haploid nuclei. This is the stage wherein genetic recombination occurs resulting in the production of new genotypes of the parasite. (f) Oocyst development: Ookinete moves to form a cyst on the midgut epithelium. In the oocyst so produced, the haploid parasites multiply repeatedly to form thousands of sporozoites. (g) Programming of sporozoites: Oocyst ruptures and sporozoites get released into haemcoel. Sporozoites migrate to the salivary glands where they are programmed to eject and enter human skin at the time when infected mosquito carrying them probes the human host for a bite to obtain a blood meal. P. knowlesi has several macacque monkeys as vertebrate hosts in addition to humans. It has been experimentally shown that the following types of malaria transmission can occur: mosquito $\rightarrow$ monkey or human; monkey $\rightarrow$ monkey; human $\rightarrow$ human. However, there is little evidence for the natural human to human transmission of knowlesi malaria. Whereas the natural transmission of all kinds of malaria in human occurs when infected mosquito bites, malaria of all kinds can also be transmitted by mother to newborn, blood transfusion, organ transplanting or usage of contaminated needles or syringes.

References

Barber et al., 2017; White, 2017; Doerig et al., 2015; Josling and Llianas, 2015; Guttery et al., 2012; Janse et al., 1986

peaks, skin vasodilates, headache, myalgia and other symptoms are felt, and the period ends following sweating and recession of clinical symptoms. The period from inoculation of sporozoites to the first appearance of clinical symptoms is the incubation period of malaria, which varies according to the causal speacies. It is $8-15,10-12,10-21,10-20$ and 18-60 days respectively in $\mathrm{Pf}, \mathrm{Pk}, \mathrm{Pv}, \mathrm{Po}$ and $\mathrm{Pm}$ malaria. The duration of erythrocytic infection to schizont rupture is $24 \mathrm{~h}$ in the $\mathrm{Pk}$ malaria, $48 \mathrm{~h}$ in $\mathrm{Pf}, \mathrm{Pv}$ and Po malaria, and $72 \mathrm{~h}$ in Pm malaria. The pattern of appearance of fever and clinical symptoms is variable with mixed infection malarias. All of the 19 drugs listed in Table 2 are schizonticidal for erythrocytic scizonts and are therefore able to provide relief from malaria. The severe malaria results when erythrocytic multiplication cycles continue uninterrupledly.
Individuals who have immunity, on account of previous malarial infections, can tolerate parasite densities such as $104 / \mu \mathrm{L}$. In immune patients, the parasite multiplication is slower and parasite clearance is faster, than in patients undergoing the first malaria infection. It is to be noted that a malaria attack does not make the individual fully immune to the subsequent attack of malarial diseases.

Some erythrocytic merozoites $(>1 \%)$ grow and differentiate via five stages into male gametocytes (microgametocytes) and female gametocytes (macrogametocytes), the precursors, respectively, of male and female gametes. In all kinds of malaria, except Pf malaria, gametocytogenesis occurs in the peripheral blood. However, in Pf malaria, several young stages are completed in deep tissues, such as 
Table 2: Structure, activity and related features of different classes of antimalarials, that are presently in use against various developmental stages of Plasmodium falciparum (Pf), Plasmodium vivax (Pv), Plasmodium ovale (Po), Plasmodium malariae (Pm) and Plasmodium knowlesi (Pk) caused human malaria(s) and genetic markers of resistance detected against the antimalarials in $P$. falciparum and $P$. vivax

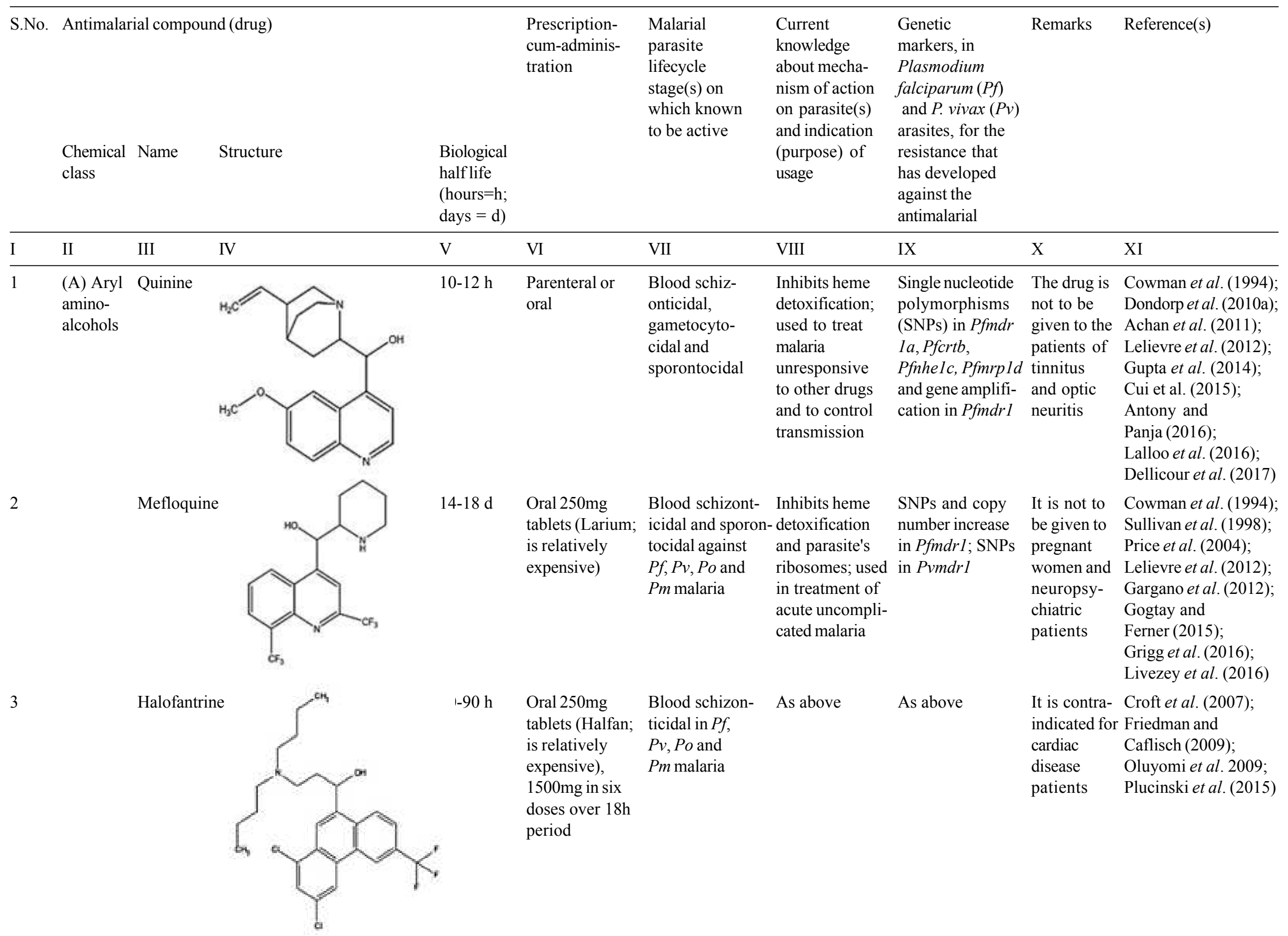




\begin{tabular}{|c|c|c|c|c|c|c|c|c|c|}
\hline I & II & III & $\mathrm{V}$ & VI & VII & VIII & IX & $\mathrm{X}$ & $\mathrm{XI}$ \\
\hline 4 & & Lumefantrin $\epsilon$ & $3-6 d$ & $\begin{array}{l}\text { Oral (artemisinin- } \\
\text { based combination } \\
\text { therapy = ACT) } \\
\text { tablets of } 120 \mathrm{mg} \\
\text { lumefantrine and } \\
\text { 20mg of artemether } \\
\text { (Coartem); four } \\
\text { tablets to be taken } \\
\text { twice a day for } 4 \mathrm{da}\end{array}$ & $\begin{array}{l}\text { Blood schizon- } \\
\text { ticidal and } \\
\text { sporontocidal }\end{array}$ & $\begin{array}{l}\text { Inhibits heme } \\
\text { de-toxification; } \\
\text { used together } \\
\text { with artemether } \\
\text { to treat acute } \\
\text { malaria }\end{array}$ & $\begin{array}{l}\text { SNPs and copy } \\
\text { number increase } \\
\text { in Pfmdrl }\end{array}$ & $\begin{array}{l}\text { Safe medicine, } \\
\text { including for } \\
\text { children of } 5 \\
\mathrm{~kg} \text { body } \\
\text { weight }\end{array}$ & $\begin{array}{l}\text { Ezzet et al. (2000); } \\
\text { Sidhu et al. (2002\&6 } \\
\text { Naobya et al. (2010); } \\
\text { Delves et al. (2012a,b); } \\
\text { Slack et al. (2012); } \\
\text { Agarwal } \text { et al. (2013); } \\
\text { Hodel } \text { et al. (2013); } \\
\text { Masanja et al. (2013); } \\
\text { Laman et al. (2014); } \\
\text { Plucinski } \text { et al. }(2015) ; \\
\text { Soniler } \text { et al. }(2017)\end{array}$ \\
\hline 5 & $\begin{array}{l}\text { (B) 4- } \\
\text { Amino- } \\
\text { quinolines }\end{array}$ & Chloroquin & $30-60 \mathrm{~d}$ & $\begin{array}{l}\text { Oral tablets of } 250 \\
\text { and } 500 \mathrm{mg} \text { (Aralen; } \\
\text { is the cheapest } \\
\text { antimalarial drug); } \\
2.5 \mathrm{~g} \text { is administered } \\
\text { in } 48 \mathrm{~h}\end{array}$ & $\begin{array}{l}\text { Blood schizon- } \\
\text {; ticidal in } P f, P v \text {, } \\
P o \& P m \text { malaria, } \\
\text { and gametocyt- } \\
\text { ocidal in } P v \\
\text { malaria }\end{array}$ & $\begin{array}{l}\text { Inhibits heme } \\
\text { detoxification; } \\
\text { used to treat } \\
\text { acute uncompli- } \\
\text { cated malaria \& } \\
\text { along with } \\
\text { Primaquine as } \\
\text { first line cure } \\
\text { for } P v \text { malaria }\end{array}$ & $\begin{array}{l}\text { SNPs in Pfcrt, } \\
\text { Pfmdrl, and } \\
\text { Pfmrpl; and } \\
\text { Pvmdrl, and } \\
\text { Pvcrt } 1\end{array}$ & $\begin{array}{l}\text { Contraindicate } \\
\text { for the patient } \\
\text { of hepatic } \\
\text { disease }\end{array}$ & $\begin{array}{l}\text { ed Sullivan et al. (1998); } \\
\text { ts Woofton (2002); } \\
\text { Rottman et al. (2010); } \\
\text { Caldarelli et al. (2012); } \\
\text { Krafts et al. (2012); } \\
\text { Ecker et al. (2012); } \\
\text { Chandra et al. (2013); } \\
\text { Price et al. (2014); } \\
\text { Galatas et al. (2017); } \\
\text { Mwanza et al. (2017); } \\
\text { Nyunt et al. (2017) }\end{array}$ \\
\hline 6 & & Amodiaquine & $5 \mathrm{~h}$ & $\begin{array}{l}\text { Oral tablets of } \\
200 \mathrm{mg} ; 25-35 \mathrm{mg} / \mathrm{kg} \\
\text { body weight over } \\
3 \mathrm{~d} \text { period }\end{array}$ & $\begin{array}{l}\text { Blood } \\
\text { schizonticidal }\end{array}$ & $\begin{array}{l}\text { Inhibits heme } \\
\text { detoxification; } \\
\text { treatment of } \\
\text { acute uncompli- } \\
\text { cated malaria and } \\
\text { alongwith sulfad- } \\
\text { oxine plus pyri- } \\
\text { methamine for } \\
\text { prophylaxis in } \\
\text { travellers }\end{array}$ & $\begin{array}{l}\text { SNPs and copy } \\
\text { number increase } \\
\text { in } P f m d r l \text { and } \\
\text { SNPs in } P f c r t \\
\end{array}$ & $\begin{array}{l}\text { Contraindi- } \\
\text { cated in } \\
\text { patients of } \\
\text { kidney and } \\
\text { liver diseases } \\
\text { and pregnant } \\
\text { and breast } \\
\text { feeding } \\
\text { women }\end{array}$ & $\begin{array}{l}\text { Kerb et al. (2009); } \\
\text { Sa et al. (2009); } \\
\text { Cairns et al. (2010); } \\
\text { Bashir et al. (2010); } \\
\text { Sutherland } \text { et al.(2011); } \\
\text { Nair } \text { et al. (2012); } \\
\text { Qiao et al. (2013); } \\
\text { Maiga et al. (2016); } \\
\text { York (2017) }\end{array}$ \\
\hline
\end{tabular}




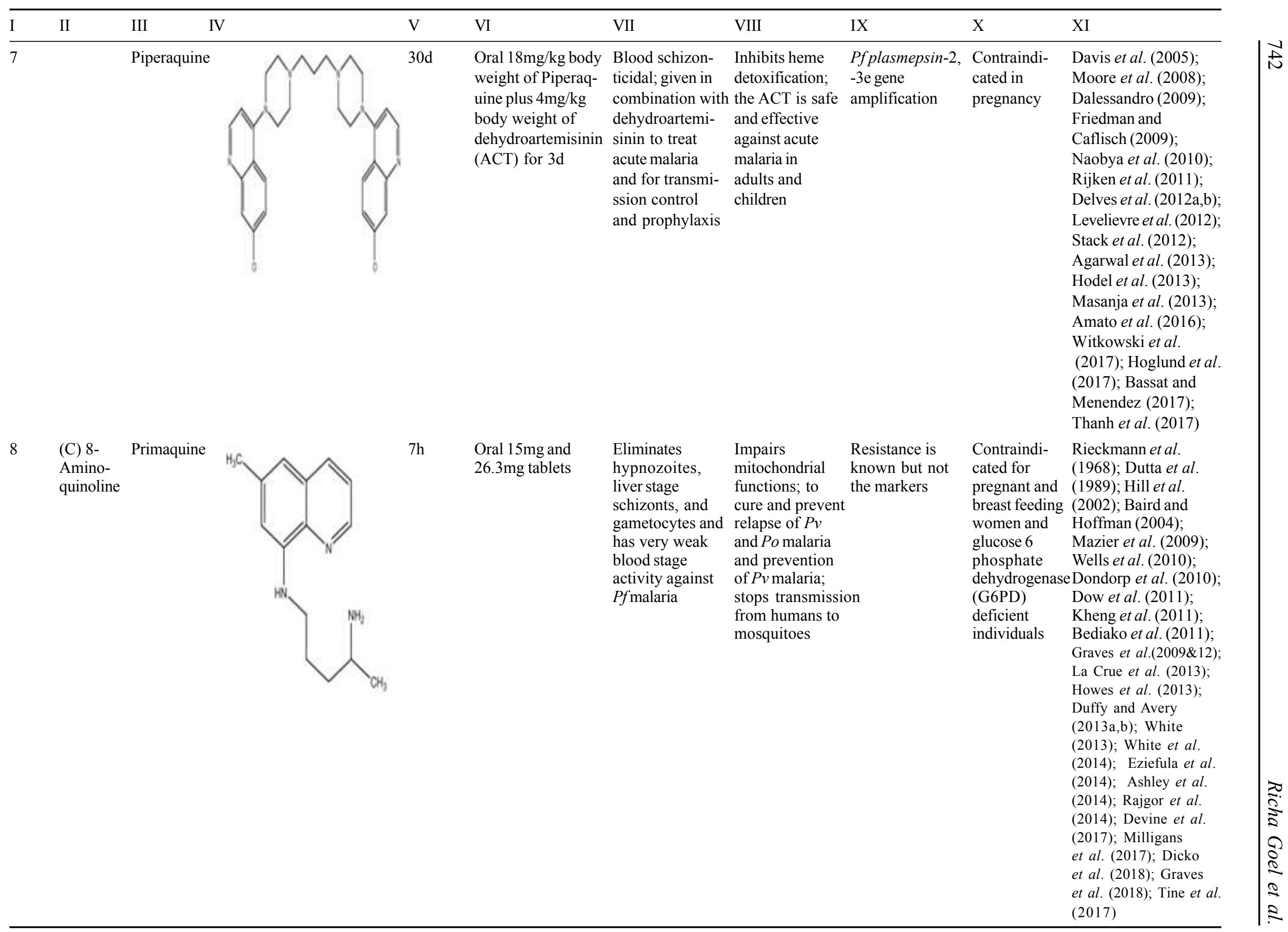




\begin{tabular}{|c|c|c|c|c|c|c|c|c|c|}
\hline I & II & III & $\mathrm{V}$ & VI & VII & VIII & IX & $X$ & XI \\
\hline 9 & $\begin{array}{l}\text { (D) } \\
\text { Mannich } \\
\text { base }\end{array}$ & Pyronaridine & $<3-8 d$ & $\begin{array}{l}\text { Oral (ACT) tablets } \\
\text { of } 180 \mathrm{mg} \text { Pyronari- } \\
\text { dine tetraphosphate } \\
\text { plus } 60 \mathrm{mg} \text { of } \\
\text { Artesunate (Pyramax } \\
\text { given one/d for } 3 \mathrm{~d}\end{array}$ & $\begin{array}{l}\text { Blood } \\
\text { schizonticidal } \\
\text { x) }\end{array}$ & $\begin{array}{l}\text { Inhibits } \\
\beta \text {-haemetin } \\
\text { formation }\end{array}$ & $\begin{array}{l}\text { SNPs in } \\
\text { Pfmrpl }\end{array}$ & $\begin{array}{l}\text { Not to be } \\
\text { given to the } \\
\text { patients of } \\
\text { liver disease }\end{array}$ & $\begin{array}{l}\text { Chang et al. (1992); } \\
\text { Auparakkitanon et al. } \\
\text { (2006); Croft et al. } \\
\text { (2012); Peatey et al. } \\
\text { (2012); Delves et al. } \\
\text { (2012); Duffy and } \\
\text { Avery (2013a,b); } \\
\text { Gupta et al. }(2014) ; \\
\text { Leang et al. }(2016)\end{array}$ \\
\hline 10 & $\begin{array}{l}\text { (E) } \\
\text { Naptha- } \\
\text { quinone }\end{array}$ & Atovaquone & $59 \mathrm{~h}$ & $\begin{array}{l}\text { Oral tablet of } 1 \mathrm{~g} \\
\text { Atovaquone and } \\
\text { 400mg Proguanil } \\
\text { (Malarone); one } \\
\text { tablet/d for } 3 \mathrm{~d} \text {, } \\
\text { lower doses for } \\
\text { children and } 25 \% \\
\text { strength tablet for } \\
\text { prevention }\end{array}$ & $\begin{array}{l}\text { Liver stage and } \\
\text { blood stage } \\
\text { schizonticidal, } \\
\text { and } \\
\text { sporonticidal }\end{array}$ & $\begin{array}{l}\text { Acts against } \\
\text { mitochondrial } \\
\text { bc1 complex and } \\
\text { inhibits parasite's } \\
\text { respiration } \\
\text { process; given in } \\
\text { combiation with } \\
\text { Proguanil to } \\
\text { treat acute } \\
\text { malaria and for } \\
\text { prophylaxis }\end{array}$ & $\begin{array}{l}\text { SNPs in } \\
P f c y t b^{\mathrm{b}}\end{array}$ & $\begin{array}{l}\text { Not to be } \\
\text { given to the } \\
\text { patients of } \\
\text { hypersensitive } \\
\text { reactions and } \\
\text { renal impair- } \\
\text { ment }\end{array}$ & $\begin{array}{l}\text { Rieckmann et al. } \\
\text { (1968); Fowler et al. } \\
\text { (1995); Srivastava and } \\
\text { Vaidya (1999); } \\
\text { Farnert et al. (2003); } \\
\text { Gil et al. (2003); } \\
\text { Camus et al. (2004); } \\
\text { Osci-Akoto et al. } \\
\text { (2009); La Crue et al. } \\
\text { (2013); Cordel et al. } \\
\text { (2013); Goodman et al. } \\
\text { (2016); Saunders et al. } \\
\text { (2016); Staines et al. } \\
\text { (2017) }\end{array}$ \\
\hline 11 & $\begin{array}{l}(\mathrm{F}) \\
\text { Antifo- } \\
\text { lates }\end{array}$ & Proguanil & $24 \mathrm{~h}$ & As above & $\begin{array}{l}\text { Mild liver stage } \\
\text { schizonticidal } \\
\text { and blood stage } \\
\text { schizonticidal for } \\
P f, P v, P o \\
\text { malaria }\end{array}$ & $\begin{array}{l}\text { Inhibits dihy- } \\
\text { drofolate reduc- } \\
\text { tase (DHFR) } \\
\text { synthesis or } \\
\text { folate synthesis; } \\
\text { the drug is admi- } \\
\text { nistered together } \\
\text { with Atovaquone } \\
\text { or Chloroquine } \\
\text { to treat acute } \\
\text { malaria and for } \\
\text { prophylaxis }\end{array}$ & $\begin{array}{l}\text { SNPs in } \\
\text { Pfdhfrg and } \\
\text { Pvdhfr }\end{array}$ & As above & $\begin{array}{l}\text { Fowler } \text { et al. (1995); } \\
\text { Srivastava and Vaidya } \\
\text { (1999); Boggild } \text { et al. } \\
\text { (2007); Osci-Akoto } \\
\text { et al. (2009); La Crue } \\
\text { et al. (2013); Cordel } \\
\text { et al. (2013); Cottrell } \\
\text { et al. (2014); Lachish } \\
\text { et al. (2016); Lalloo } \\
\text { et al. (2016); Saunders } \\
\text { et al. (2016); } \\
\text { Staines } \text { et al. (2017) }\end{array}$ \\
\hline
\end{tabular}




\begin{tabular}{|c|c|c|c|c|c|c|c|c|c|}
\hline I & II & III & $\mathrm{V}$ & VI & VII & VIII & IX & $\mathrm{X}$ & XI \\
\hline 12 & & Pyrimethamine & $<3->4 d$ & $\begin{array}{l}\text { Oral tablet of } 25 \mathrm{mg} \\
\text { Pyrimethamine and } \\
500 \mathrm{mg} \text { of Sulfado- } \\
\text { xine (Fansidar; is a } \\
\text { cost effective drug); } \\
\text { adults to take 2-3 } \\
\text { tablets/week }\end{array}$ & $\begin{array}{l}\text { Mild liver stage } \\
\text { schizonticidal, } \\
\text { blood stage } \\
\text { schizonticidal } \\
\text { and sporonto- } \\
\text { cidal }\end{array}$ & $\begin{array}{l}\text { Inhibits dihy- } \\
\text { drofolate reduc- } \\
\text { tase (DHFR) } \\
\text { synthesis and } \\
\text { thereby folate } \\
\text { synthesis; it is } \\
\text { given along with } \\
\text { sulfadoxine to } \\
\text { cure acute malaria } \\
\text { even in pregnant } \\
\text { women }\end{array}$ & $\begin{array}{l}\text { As above } \\
\text { a, }\end{array}$ & $\begin{array}{l}\text { Not to be } \\
\text { given to the } \\
\text { patients of } \\
\text { megaloblastic } \\
\text { anemia and } \\
\text { folate } \\
\text { deficiency }\end{array}$ & $\begin{array}{l}\text { Sibley et al. (2001); } \\
\text { Gatton et al. (2004); } \\
\text { Mugittu et al. (2005); } \\
\text { Donderp et al. (2010); } \\
\text { Tanaka and Williams } \\
\text { (2011); Gujjar et al. } \\
\text { (2011); Kiszewski et al. } \\
\text { (2011); Huang et al. } \\
\text { (2012); Calderon et al. } \\
\text { (2012); Duffy and } \\
\text { Avery (2013a,b); } \\
\text { Gadalis (2013); Mishra } \\
\text { (2014); Misra et al. } \\
\text { (2014); Desai et al. } \\
\text { (2016); Goel et al. } \\
\text { (2016); Cisse et al. } \\
\text { (2017); Maiga et al. } \\
\text { (2017); Ayubu and } \\
\text { Kidima (2017) }\end{array}$ \\
\hline 13 & & Sulfadoxine & $<4->8 d$ & As above & $\begin{array}{l}\text { Blood stage } \\
\text { schizonticidal in } \\
\text { Pf malaria but } \\
\text { relatively ineffe- } \\
\text { ctive in } P v \\
\text { malaria }\end{array}$ & $\begin{array}{l}\text { Inhibits the } \\
\text { dihydropteroate } \\
\text { synthesis } \\
\text { (DHPS) and } \\
\text { thereby folate } \\
\text { synthesis; } \\
\text { indication as } \\
\text { above }\end{array}$ & $\begin{array}{l}\text { SNPs in } \\
\text { Pfdhpsh and } \\
\text { Pvdhps }\end{array}$ & $\begin{array}{l}\text { As above and } \\
\text { also not to be } \\
\text { given in the } \\
\text { patients of } \\
\text { sulphur } \\
\text { allergy }\end{array}$ & $\begin{array}{l}\text { As above and } \\
\text { Rieckmann } \text { et al. } \\
\text { (1968); } \\
\text { Pukrittayakamee } \\
\text { et al. (2000); Ayubu } \\
\text { and Kidima (2017); } \\
\text { Guhman and } \\
\text { Slutsker (2017) }\end{array}$ \\
\hline 14 & $\begin{array}{l}(\mathrm{G}) \\
\text { Anti- } \\
\text { biotics }\end{array}$ & Tetracycline & $\begin{array}{l}\text { 8-11h } \\
\text { (Sumycin }\end{array}$ & $\begin{array}{l}\text { Oral } 250 \mathrm{mg} \text { tablets } \\
\text { and } \\
\text { other brands; is } \\
\text { cost effective }\end{array}$ & $\begin{array}{l}\text { Slow acting liver } \\
\text { and blood } \\
\text { stage } \\
\text { schizonticidal }\end{array}$ & $\begin{array}{l}\text { Protein syn- } \\
\text { thesis inhibitor; } \\
\text { given along } \\
\text { with Quinine }\end{array}$ & $\begin{array}{l}\text { Resistance is } \\
\text { not known }\end{array}$ & $\begin{array}{l}\text { Not to be } \\
\text { given to } \\
\text { children of } \\
<8 \text { y age }\end{array}$ & $\begin{array}{l}\text { Ruiz-Sanchez et al. } \\
\text { (1956), Dahl et al. } \\
(2006) \text {; Briolant et al. } \\
\text { (2008); Tan et al. } \\
\text { (2011); Gaillard et al. } \\
\text { (2015 and 2016) }\end{array}$ \\
\hline
\end{tabular}




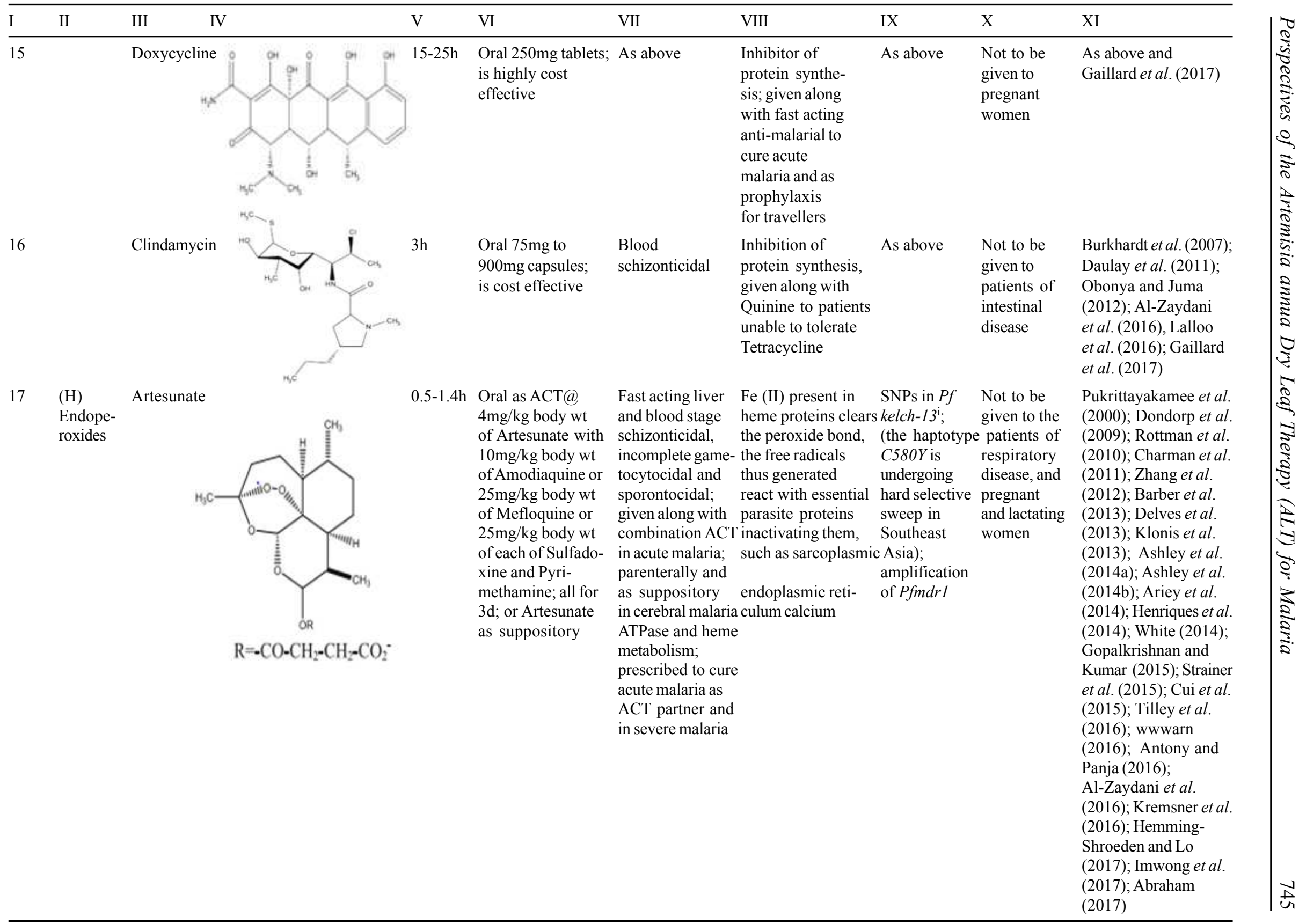




\begin{tabular}{|c|c|c|c|c|c|c|c|c|c|c|}
\hline I & II & III & IV & $\mathrm{V}$ & VI & VII & VIII & IX & $\mathrm{X}$ & XI \\
\hline 18 & & $\begin{array}{l}\text { Dihydro- } \\
\text { artemisinin }\end{array}$ & 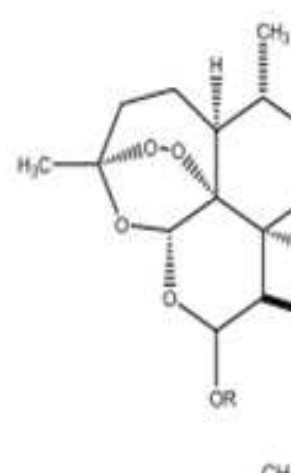 & $\mathrm{R}=\mathrm{H}$ & $\begin{array}{l}\text { As shown at } \\
\text { serial no. } 7\end{array}$ & $\begin{array}{l}\text { Fastest acting } \\
\text { Artemisinin } \\
\text { derivative that } \\
\text { does not allow } \\
\text { trophozoite } \\
\text { formation and is } \\
\text { gametocytocidal } \\
\text { and sporontocida }\end{array}$ & $\begin{array}{l}\text { Mode of action as } \\
\text { above; treatment } \\
\text { of acute malaria as } \\
\text { an ACT component }\end{array}$ & As above & As above & $\begin{array}{l}\text { Sinclair et al. (2009); } \\
\text { Keating (2012); } \\
\text { Tarning et al.(2012); } \\
\text { Gargano et al.(2012); } \\
\text { Zani et al. (2014a,b); } \\
\text { Amartunga et al. } \\
\text { (2016); Tillay et al. } \\
\text { (2016); Kakaru et al. } \\
\text { (2016); Anato et al. } \\
\text { (2017); Bassat and } \\
\text { Menandez (2017), } \\
\text { Phu et al. (2017) }\end{array}$ \\
\hline 19 & & Artemether & $\mathrm{R}=\mathrm{Me}$ & $4-11 \mathrm{~h}$ & $\begin{array}{l}\text { As shown at } \\
\text { serial no. 4; the } \\
\text { drug is lipid } \\
\text { soluble and is } \\
\text { used orally, } \\
\text { rectally and } \\
\text { intramuscularly }\end{array}$ & $\begin{array}{l}\text { Mode of action } \\
\text { like Artesunate; } \\
\text { As an ACT it is } \\
\text { a frontline drug } \\
\text { for acute malaria }\end{array}$ & As above & As above & As above & $\begin{array}{l}\text { Mc Gready et al. } \\
\text { (2008); Hatz et al. } \\
\text { (2008); Achan et al. } \\
\text { (2009); Sutherland et al. } \\
\text { (2012); Agarwal et al. } \\
\text { (2013); Hodel et al. } \\
\text { (2013); Esu et al. } \\
\text { (2014); Chandira et al. } \\
\text { (2014); Sonden et al. } \\
\text { (2017); Rutledge et al. } \\
\text { (2017); Chikwu et al. } \\
\text { (2017); Phuc et al. } \\
\text { (2017) }\end{array}$ \\
\hline
\end{tabular}

a- $\mathrm{i}=$ Antimalarial resistant drug alleles: $\mathrm{a}, m d r l=$ Multi-drug resistance gene on chromosome $5 ; \mathrm{b}, \mathrm{crt}=$ Chloroquine resistance transporter gene on chromosome $7 ; \mathrm{c}, n h e \mathrm{l}=$ Sodium/ hydrogen exchanger gene on chromosome 13; $\mathrm{d}, m r p l=$ Multi-drug resistance associated proteins gene on chromosome 1; e, plasmepsin-2, $-3=$ Aspartyl (protease plasmepsin gene located on chromosome 4; f, cyt $b=$ cytochrome B gene on mitochondrial genome; $\mathrm{g}, d h f \mathrm{r}=$ Dihydrofolate reductase gene on chromosome $8 ; \mathrm{h}$, dhps = Dihydropteroate synthetase gene on chromosome 4; i, kelch-13= Kelch 13 propeller gene located on chromosome 13, (the gene product has three domains an apicomplex domain, a BIB/POZ domain and a 3 -propeller Kelch domain) 
bone marrow and only the final stage is accomplished in the blood stream. Generally, the gametocytes are short-lived, except that in Pf malaria, once formed they remain viable for months. The gametocytes are not responsible for any clinical symptoms. The following anti-malarials are able to block gametocyte formation: quinine and chloroquine in $\mathrm{Pv}$ and $\mathrm{Pm}$ malarias; and primaquine and artemisinins in all kinds of malarias. The artemisinins do not eliminate gametocytes completely.

The route of malaria spread in human is human $\rightarrow$ female mosquito $\rightarrow$ human. Mosquitoes transmit the gametocytes from infected humans as a part of their blood meal. In the mosquito gut, the gametocytes exit erythrocytes and undergo gametogenesis. A female gametocyte develops into a female gamete. A male gametocyte divides into 8 male gametes, each male gamete is flagellated. The gametes, gametocytes, merozoites and sporozoites are all haploid $(n=14)$. The haploid male and female gametes fuse to form a zygote $(2 n=28)$ which differentiates into an ookinete. The ookinete migrates to the epithelial cell wall of the gut to form an oocyst. The oocyst undergoes meiosis and subsequently the haploid products in it multiply to produce thousands of sporozoites. Upon rupture of oocysts, the sporozoites migrate to salivary glands where they get programmed for inoculation into human host via carrier mosquitoe's bite. The sporogony cycle from gamete formation to sporozoite production in oocysts and their accumulation in salivary glands is blocked by several antimalarial drugs, including the following: quinine, mefloquine, lumefantrine, atavaquone, proguanil, primaquine, methylene blue and pyromethamine.

\section{Treatments Based on Currently Used Antimalarial Drugs}

The Table 3 presents a summarized account of first line treatments, for acute and severe malaria caused by different species of malaria parasites in adults, pregnant women and young children, recommended by WHO. The recommendations are a result of the scores of trials carried out, for the cure of different kind of malaria in endemic areas owing to their occurrence in Africa, Americas, Pacific islands, Southeast-and South-Asia, on adult men and women, pregnant and lactating women and young children. Some of the references on which the WHO recommendations are based are given at the bottom of the Table 3. The dosages of drugs for children are to be adjusted with the body weight. Some drugs are prescribed when malarial patients suffer from concurrent ailments or inherited metabolic deficiencies, the prescriptions for each of the antimalarial drugs are given in the Table 2. Most importantly, primaquine is not to be administered to pregnant and/or breast feeding women. Because severe malaria patients can suffer from blockage in blood flow, filling up of fluid in lung's air sacks, clotting in blood vessel, renal failure, and/or seizures etc., they must be treated under intensive care environment. Any concurrent bacterial infection in malaria patients should receive immediate attention, along with malaria treatment.

The options for the treatment of uncomplicated malaria in adult men and women are: artemether + lumefantrine; dihydro-artemisinin + piperaquine; atavaquone + proguanil; quinine + doxycycline. Along with a drug combination, a dose of primaquine ensures control of transmission. The treatment for $\mathrm{Pv}, \mathrm{Po}$ or mixed malaria is one of the following: artemether + lumefantrine; dihydro-artemisinin + piperaquine; chloroquine. For $\mathrm{Pm}$ and $\mathrm{Pk}$ malaria, the drug recommended is chloroquine. The drug options for children against Pf malaria are: artemether + lumefantrine; dihydroartemisinin + piperaquine; atavaquone + proguanil; quinine + clindamycin. Chloroquine is the drug recommended for children against $\mathrm{Pv}, \mathrm{Po}, \mathrm{Pm}$ and $\mathrm{Pk}$ malaria. The pregnant women afflicted with any kind of malaria are recommended to use quinine + clindamycine or artemether + lumefantrine and those having non- Pf malaria are also recommended chloroquine. The treatment options for the patients with severe malaria in adult men and women caused by all kinds of parasites are: intravenous artesunate for one or more days until the patient can swallow tablets, but not more than 5 days, followed by a full course of artemether + lumefantrine, dihydro-artemisinin + piperaquine or quinine + tetracycline; or intravenous quinine for 2 days or until the patient can begin to swallow tablets, followed by a full course of quinine + doxycycline. In the severe malarial cases caused by $\mathrm{Pv}$ or $\mathrm{Pk}$, the intravenous treatments are to be followed by full course of chloroquine. The pregnant women patients with severe Pf malaria are to be given intravenous artesunate or quinine treatments, like that for adult 
Table 3: The prevalent antimalarial treatment regimens against un-complicated and complicated malaria(s) in adults, pregnant and breast feeding women and children

S.No. Indicative malarial

condition

$1 \quad$ (A) Uncomplicated malaria: (i) in adults

2 (ii) in pregnant women

3 (iii) in children $(<12$ years $)$

4

(B) Severe or complicated malaria: (i) in adults (ii) in pregnant women $(<12$ years $)$

7

\section{Relapse} (prevention):

(i) in adults

(ii) in pregnant As above and breast feeding women days

As above

Malaria caused by

Plasmodium falciparum

Oral: Artemether + Lumefantrine (the drug(s) of choice $)^{\mathrm{a}}$; Dihydroartemisinin + Piperaquine (not to be administered to patients suffering from cardiac condition(s) $)^{\text {b; }}$; Atovaquone+ Proguanil (known to produce pronounced gastrointestinal side effects) ${ }^{\mathrm{c}}$; Quinine + Doxycycline $^{\mathrm{d}}$; and a single dose of $0.25 \mathrm{mg} / \mathrm{kg}$ body weight of Primaquine on the first day or $15 \mathrm{mg} / \mathrm{Kg}$ of Methylene blue for three

Oral: Quinine + Clindamycin (in: all trimesters) ${ }^{\mathrm{e}}$; or Artemether + Lumefantrine (in all trimesters)

Oral: Quinine + Clindamycin ${ }^{\mathrm{e}}$; Atovaquone + Proguanil $^{\mathrm{f}}$; Artemether + Lumefantrines; or Dihydroartemisinin + Piperaquine $^{\text {h }}$

Intravenous Artesunate for $24 \mathrm{~h}$ or more (or until the patient can swallow tablets, but not more than 5 days) $)^{\mathrm{i}}$, followed by a full course of Artemether + Lumefantrine ${ }^{\text {a }}$ or of Dihydroartemisinin + Piperaquineb or Intravenous Artesunate treatmenti followed by a full course of Quinine + Doxycycline ${ }^{\mathrm{d}}$; or alternatively Intravenous Quinine $^{j}$ for 48 hours or until the patient is able to swallow tablets, followed by oral Quinine + Doxycycline ${ }^{\mathrm{k}}$

Intravenous Artesunatei, followed by Artemether + Lumefantrine or Dihydroartemisinin + Piperaquine as in item 4 above; or Intravenous Quinine followed by a course of Quinine + Clindamycinl

A rectal suppository dose of upto $100 \mathrm{mg}(10 \mathrm{mg} / \mathrm{kg}$ body weight) Artesunate followed by intravenous Artesunate or Quinine and thereafter dihydroartemisinin + Piperaquine or Quinine + Clindamycin; as for adults with dosage adjusted as per body weight

Not applicable

\section{Plasmodium vivax, $\quad$ P. vivax, P. ovale, P. ovale or of these $\quad$ P. malariae or mixed with $P$. falciparum $P$. knowlesi}

Oral: Artemether + Oral: Chloroquine ${ }^{\mathrm{m}}$

Lumefantrine ${ }^{\mathrm{a}}$;

Dihydroartemisinin +

Piperaquine $^{\mathrm{b}}$ or

Chloroquinem
As in column 2; item 2; As in column 3; or Chloroquine $^{\mathrm{m}} \quad$ item 2

Chloroquinen

Chloroquinen

As in column 2; item 4; As in column 2; or intravenous artesunate item 4 treatment followed by

full course of

Chloroquine

Oral: Chloroquine (in all As in column 2; trimesters); Artemether item 4

+ Lumefantrine

(in all trimesters)

As in column 2

As in column 2
Primaquineo (not to be As in column 3 administered to Glucose6-phosphate dehydrogenase $=$ G6PD deficient $)^{\mathrm{p}}$

Chloroquine ${ }^{q}$ followed As in column 3 by Primaquine upon withdrawl of breast feeding

$\mathrm{a}=4$ tablets (such as of Coartem) followed by 4 tablets at $0,8,24,36,48$ and 60 hours; $\mathrm{b}=3$ or 4 tablets (such as of Eurartesim) daily for 3 days; $c=4$ tablets (such as of Malarone) daily for 3 days; $d=600 \mathrm{mg}$ Quinine sulphate every $8 \mathrm{~h}$ for 5-7 days and 200mg Doxycycline daily; e $=600 \mathrm{mg}$ Quinine sulphate every $8 \mathrm{~h}$ plus $450 \mathrm{mg}$ Clindamycin every 8 hours for 7 days; $\mathrm{f}=1$ to 4 Malarone paediatric tablets (as per body weight from $=10 \mathrm{~kg}$ to $=40 \mathrm{~kg}$ ); $\mathrm{g}=1-4$ tablets at $0,8,24,36,48$ and 60 hours (as per body weight from $=15 \mathrm{~kg}$ to $=35 \mathrm{~kg}$ ); $\mathrm{h}=1 / 2$ to 3 tablets followed by equal amount at 24 and 48 hours (as per body weight $=10 \mathrm{~kg}$ to $=60 \mathrm{~kg}$ ); $=2.4 \mathrm{mg} /$ $\mathrm{kg}$ body weight injection of Artesunate at 0,12 and $24 \mathrm{~h}$ and thereafter daily; $\mathrm{j}=$ starting dose of $20 \mathrm{mg} / \mathrm{kg}$ body weight of Quinine hydrochloride in $5 \%$ dextrose over a $4 \mathrm{~h}$ period, followed by $10 \mathrm{mg} / \mathrm{kg}$ body weight of Quinine hydrochloride every $8 \mathrm{~h}$ for upto $48 \mathrm{~h}$ and later every $12 \mathrm{~h} ; \mathrm{k}=600 \mathrm{mg}$ Quinine sulphate three times a day for 5 to 7 days from the start of Quinine therapy, plus oral $200 \mathrm{mg}$ of Doxycycline each day for 7 days; 1 = Intravenous Quinine therapy to be followed by oral quinine, like in k, except in place of Doxycycline, Clindamycin $(450 \mathrm{mg})$ will be administered 3 times a day for a period of 7 days; $\mathrm{m}=620 \mathrm{mg}$ at $0 \mathrm{~h}, 310 \mathrm{mg}$ at $8 \mathrm{~h}$ and $310 \mathrm{mg}$ on day 2 and $3 ; \mathrm{n}=10 \mathrm{mg}$ starting dose, then $5 \mathrm{mg} / \mathrm{kg}$ at $8 \mathrm{~h}$ and also on day 2 and $3 ; \mathrm{o}=15$ to $30 \mathrm{mg} /$ day or $0.2-0.5 \mathrm{mg} / \mathrm{kg}$ body weight $/ \mathrm{day}$ 
for 14 days depending on body weight; $\mathrm{p}=$ The G6PD deficients may be adminstered $0.75 \mathrm{mg} / \mathrm{kg}$ of Primaquine per week for 8 weeks; $\mathrm{q}=500 \mathrm{mg}$ each week

References: Dicko et al. (2018); Abraham (2017); Antinori et al. (2017); Dellicour et al. (2017); Phuc et al. (2017); Plucinski et al. (2017); Thanh et al. (2017); Tine et al. (2017); Baird et al. (2016); Gutman et al. (2016); Herchline (2016); Kakaru et al. (2016); Kremsner et al. (2016); Lalloo et al. (2016); Pekyi et al. (2016); Sirima et al. (2016); Verlinden et al. (2016); White (2016); Kheng et al. (2015); Kumar et al. (2015); Shanks et al. (2015); Sharma et al. (2015); Eziefula et al. (2014); White et al. (2014); WHO (2014); Barber et al. (2013); Cordel et al. (2013); Delves et al. (2013); Gogtay et al. (2013); Singh and Daneshwar (2013); Eder et al. (2012); Keating (2012); Obonyo and Juma (2012); Achan et al. (2011); Daulay et al. (2011); Rijken et al. (2011); Kiszewski et al. (2011); Dondorp et al. (2010); RCOG (2010); Achan et al. (2009); Sinclair et al. (2009); Hatz et al. (2008); Mc Gready et al. (2008); Hill et al. (2006); Karunajeewa et al. (2006); Kumar and Srivastava (2005); Maitland et al. (2005); Baird and Hoffman (2004); Dondorp et al. (2005); Newton et al. (2013); van Hansbrock et al. (1996); White et al. (1983); WHO-HTM-GMP-2017.9-org.pdf; www.contrmicrb.org/new/bo.5.asp; www.cdc.gov/ malaria/diagnosis_treatment/treatment.html; www.who.int/malaria/publications/atoz/9789241548528/en; www//apps.who.int/iris/ bitstream/10665/181162/1/9789241509244_eng.pdf

men and women. Whereas artesunate treated pregnant women patients are to be given a full oral course of artemether + lumefantrine or dihydro artemisinin + piperaquine, those who received intravenous quinine will be given full oral course of quinine + clindamycin. The severely ill pregnant women, with any non-Pf malaria, will be given a full course of oral chloroquine or atremether plus lumefantrin, irrespective of the trimester of pregnancy. Young children with complicated malaria are to be first treated with artesunate given rectally, followed by the treatments (with dose adjustment according to the patients's body weight) recommended for severely ill adult patients.

\section{Natural Selection of Genetic Resistance to Currently Used Antimalarial Drugs, in Malarial Parasites}

Like other organisms, human malarial parasite species are endowed to evolve, by induction of new mutations, amplification of variation by genetic recombination and selection of variant genotypes, for improved adaptation to changing environmental conditions, which in their case include; lethal anti-malarial drugs used singly and in combinations. The genetic variants of parasites become resistant to a drug when the gene product(s) targeted by the drug have become modified or the drug does not reach the site of its action because the process of its transport is disabled or it is effluxed out from its site of action. Drug resistance is acquired via selection of mutations that result in over expression and/or increased activity of one or more of target gene function(s) or deactivation of one or more host protective gene function(s). Several life cycle characteristics of malarial parasites, such as these mentioned below, are favourable for selection of drug resistance imparting mutations: (a) rapid rate of genome replication (Agarwal et al., 2017) ; (b) high mutation rate per genome replication cycle (Hamilton et al., 2017; William et al., 2017); (c) large population size within infected human and mosquito hosts (Table 1; Churcher et al., 2017); and (d) enormity of overall population size of parasites in humans and mosquito hosts in malaria endemic areas (Duffy et al., 2017). Besides, selection of drug resistant mutations also depends on the drug pharmacokinetics, purity and dosage; irregular and sub-optimal intake of drug favours selection of genetic drug resistance in parasite (Anyanwu et al., 2017). The combinatorial use of drugs with differing pharmacokinetics and mode of action, such as in ACTs, delay development of resistance against the drugs (Dondorp et al., 2009). Drug resistance in malarial parasites is known to have arisen faster for those drugs that targeted only one gene function in them. For example, resistance against proguanil, atavaquone, pyrimethamine and sulfadoxine was selected and became observable within one or two years of their large scale usage (Paloque et al., 2016). Contrariwise, resistance against artemisinins, which have multiple targets in parasites, was observable 26 years after their large scale therapeutic adoption (Paloque et al., 2016).

The malarial parasite cells have in them a nuclear genome $(\mathrm{n}=14)$, and copies of mitochondrial and apicoplast organelle genomes (Gardner et al., 2002; Vaidya and Mather, 2009; Rai et al., 2017). The comparison of genome sequences of the sensitive and resistant isolates (clones) of parasites have allowed identification and mapping of molecular markers (point mutation, deletion and insertion polymorphisms) associated with anti-malarial 
resistance. The molecular markers for resistance to different drugs have been found to be located on several different nuclear chromosomes and resistance to atovaquone to be located on the mitochondrial genome (Sharma, 2005; Antony and Parija, 2016; Menard and Dondorp, 2017). In the Table 2, the column VIII gives information about the target(s) of the 19 drugs; and the column IX lists molecular markers found associated with resistance selected in parasites for 15 drugs. The chromosomes in which drug resistant mutations are located are identified in the legend of Table 2.

Resistance of parasites towards tetracycline, doxycycline and clindamycin has not been observed and the identity of gene polymorphism(s) responsible for resistance against primaquine is yet to be established. It will be seen that mutations in the $C R T$ and $M D R 1$ genes render the parasite variably resistant to several drugs. The $P f$ crt polymorphism affects response of the parasite to quinine, amodiaquine, piperaquine and lumefantrine in addition to giving resistance to chloroquine. Pf $m d r 1$ poses resistance to chloroquine, quinine, mefloquine, halofantrine, lumefantrine and artemisinin. There are examples of different mutant alleles in the same gene inducing differential responses in the parasite; mutations in the amino terminal and carboxy terminal of Pf MDRI are of this type (Cui et al., 2015; Antony and Parija, 2016; Menard and Dondorp, 2017). Mutational polymorphism in the Pf kelch 13 gene has been responsible for resistance to artemisinin (Ashley et al., 2014; Miotto et al., 2015; Takala-Harrison et al., 2015; Amato et al., 2016; Li et al., 2017); 20 SNPs are known to have arisen independently in different locations - an example of multiple origin of soft sweep (adaptation to ART; Pennings and Hermisson, 2006). Among the Pf $k 13$ mutations, the C580Y allele not only imparted ART resistance to Plasmodium falciparum, but made the parasite fitter (Imwong et $a l ., 2017)$. It got selected in the background of $P f$ crt, Pf dhps, Pfdhfr and Pfmrdl mutations and its hard sweep has spread the allele widely in southeast Asia (WHO-multidrug-resistant-lineages-; HemmingSchroedar and Lo, 2017; Imwong et al., 2017; Thanh et al., 2017). A symptom of ART resistance due to a C580Y type mutation is recrudescence or reappearance of Pf infection upon depletion or removal of artemisinin.
Many ring stage intra-erythrocytic C580Y parasites enter a quiescent state, because upregulation of the UPR (unfolded protein response) signaling pathway in them allows repair of proteins that underwent alkylation or oxidation, by free radicals released by disintegration of the peroxide bridge in ART when it comes in contact with iron from haemoglobin. The quiescent parasites are supported by minimal energy metabolism taking place in the parasite's apicoplast and mitochondria. Quiescent parasites breakout as soon as ART is depleted (Mbengue et al., 2015; Paloque et al., 2016). Recently (Rossi et al., 2017), emergence of $P$. falciparum strains with pfmdr1, pfplasmepsin2 and pfkelch13 $580 Y$ triple mutations has been recorded in Cambodia.

There is emergent danger of this (C580Y type) and other multi-drug resistant strains getting entry into India and Africa. There is also evidence for de novo ACT resistance development in African areas of high Pf malaria endemicity (Lu et al., 2017; Daddy et al., 2017). Another observation of great concern is that artemisinin-resistant Pf clinical isolates, including perhaps the ACT resistant ones, can infect diverse mosquito species that transmit malaria in Southeast Asia and Africa (St. Laurent et al., 2015). WHO has developed a global technical strategy to control and eliminate malaria worldwide by 2030 (WHO:GST Malaria_Eng.pdf). Some leading workers in this field have proposed additional strategies for malarial treatment and vector control and there has been emergence of a new treatment- the $A$. annua dry leaf therapy (ALT) for treatment of drug resistant malaria, which are discussed below.

\section{Strategies Proposed to Treat and Control Multidrug-Resistant Malaria}

The studies summarized in table 2 shows that resistance has developed against antimalarial drug in current use singly or in two drug combinations. It is visualized that in the absence of new drugs and vaccines (Kazmin et al., 2017; Zhang et al., 2018) in the near future, there is an urgent need to use the existing drugs in better ways and new combinations. The two treatments advised for chloroquine resistant Pv malaria are: (a) dihydroartemisinin + piperaquine with a dose of primaquine (White, 2016), and (b) administration of verapmil, the calcium channel blocker which serves as a chemo sensitizer, along 
with chloroquine to improve drug efficiency (Verlinden et al., 2016). The possible treatments advised for ACT resistant Pf malaria are: (a) A new ACT combination of artesunate + pyronaridine to be introduced as treatment (White, 2016). (b) ACTs such as dihydroartemisinin + piperaquine and artesunate + mefloquine be used rotationally (Dondorp et al., 2017; Menard and Dondorp, 2017). (c) The period of use of prevalent ACTs to be extended from 3 days to up to 7 days (Dondorp et al., 2017; Menard and Dondorp, 2017). (d) ACTs to be used as combinations of a artemisinin drug with two partner drugs, such as artemether + lumefantrine + amodiaquine, and dihydroartemisinin + piperaquine + mefloquine (Shanks et al., 2015; Verlinden et al., 2016; Dondorp et al., 2017; Menard and Dondorp, 2017). (e) The double and triple drug ACTs to be used sequentially (Verlinden et al., 2016). (f) The combination of fosmidomicin and piperaquine to serve as a sure cure (MomboNgoma et al. 2017). Another important suggestion is administration of a dose of the drug ivermectin in endemic areas along with the ACT or singly periodically on a mass scale (Dondorp et al., 2017; Menard and Dondorp, 2017). Ivermectin taken by mosquitoes along with the blood meal of ivermectin administered humans will have killing effect on them, thereby drastically controlling the malarial transmission (Chaccour et al., 2013; Kumar et al., 2015).

An entirely new strategy to treat multi-drug (ACT) resistant malaria has been developed, wherein tablets made of dried leaves of the A. annua plant (natural resource of artemisinin drugs) are used (Daddy et al., 2017). The origin and essential features of this highly affordable malaria therapy are discussed below.

\section{Artemisia Annua Dry Leaf Antimalarial Therapy (ALT)}

The ALT has been earlier called as the whole Plant based Artemisinin Combination Therapy (pACT; Weathers et al., 2014a). pACT was called a combination therapy because of the involvement of artemisinin and other metabolites present in the leaves of $A$. annua in the antimalarial therapeutic effect of Artemisia annua dry leaves (Weathers et al., 2011, 2013, 2014b a and b; Elfawal et al. 2012; Onimus et al., 2013; Weathers and Towler, 2014; Desrosiers and Weathers, 2016; Daddy et al., 2017). ALT is unlike the conventional ACTs (mentioned in Tables 2 and 3 ), in which the artemisinin component, extracted from A. апnиa (Kumar et al., 2000; Misra et al., 2014) or artemisinin synthesizing transgenic tobacco or Physcomitrella patens whole plant (Malhotra et al., 2016; Ikram et al., 2017), or semi-synthesized from Artemisia annua produced natural precursor(s) (Paddon et al., 2013; Paddon and Keasling, 2014; Ikram and Simonsen, 2017; Kung et al. 2018) is present in its derived pharmaceutical forms such as artesunate, artemether and dihydroartemisinin. ALT is a non-pharmaceutical antimalarial treatment that depends on artemisinin and many other metabolites naturally biosynthesized and present in the leaves of Artemisia annua plant, but for many of which the mode(s) of antimalarial action remains to be revealed. To get WHO recommendation, ALT has to go through extensive, essential, fundamental and clinical research which needs to demonstrate that ALT is safe, efficacious and would not promote development of resistance to artemisinin in malarial parasites (WHO, 2012).

ALT uses standardized tablets as the antimalarial drug prepared by compressing the dried pulverized leaves, harvested from cultivated plants of specific variety(ies) of Artemisia annua, which contain $>1 \%$ artemisinin (Weathers and Towler, 2014; Daddy et al., 2017). The origin of ALT, as a dependable medicine against multi-drug-resistant malaria, is based on information from historical texts and a number of experimental findings. Some of the important empirical basis for ALT is annotated below:

(a) There is recorded evidence that the Chinese people have been using $A$. annua material as a remedy for fever and chills, such as those associated with malaria. One of the effective material consumed as traditional medicine was the consumption of juicy extract of water soaked $A$. annua leafy stems. The chinese traditional medicine literature does not report any case of resistance development against $A$. апnиа treatment used (Bensky and Barolet, 1990; Dhingra et al., 1999; Hongwen and Shouming, 2002; Hsu, 2006).

(b) The A. annua plant material has been used by human populations in various parts of the world, where the species existed naturally for various 
purposes, including for medicinal uses and as an item of food for livestock and humans, without notice of any harmful effects (Bansky and Barolet, 1990; Brisibe et al., 2009; Yimer and Sahu, 2016) and therefore the species has been granted the GRAS (Generally Recognized As Safe) rating. Accordingly, A. annua leaves in amounts d" $30 \mathrm{~g}$ dry weight / day can be safely consumed (Duke, 2001; Wall and Watson, 2017).

(c) In a study, batches of healthy mice were orally fed on one hand, with an amount of artemisinin in its pure form, and on the other,were fed an equal amount of artemisinin in the form of $A$. annua dried leaves. The blood stream of mice fed with dry leaves contained $>40$ times more artemisinin, as compared to mice fed with pure artemisinin. Mice were required to be fed with $>45$ fold more of pure artemisinin (as a component of the normal mouse food) than artemisinin in dry $A$. annua leaves so that artemisinin could be detected in mouse blood stream (Weathers et al., 2011).

(d) In another study, it was observed that oral administration of the Artemisia annua leaves to the Plasmodium chabaudi - infected mice killed the parasite without causing toxicity to mice (ICIPE 2005; Elfawal et al., 2012; Onimus et al., 2013). It was further found that parasitaemia in the infected mice was reduced at least five fold more by a single dose of $A$. annua leaves as compared to an equivalent dose of pure artemisinin, and the effect of dry leaves lasted longer than that of pure artemisinin (Elfawal et al., 2012). The experiments at $\mathrm{c}$ and $d$ above suggested that the presence of metabolites other than artemisinin in the dry leaves of $A$. annua improved both the bioavailability of artemisinin in the blood stream and therapeutic efficacy of artemisinin in the infected red blood cells. These possibilities were evidenced by correlating the phytochemistry of $A$. annua leaves with the response of healthy and parasite infected mice to feeding of pure artemisinin versus $A$. апnua leaves, as above and below in e and $\mathrm{f}$. Recently, using $\mathrm{CaCo}-2$ model of intestinal transport, the digestates of A. апnиa dried leaves were found to improve the artemisinin transport by $37 \%$ (Desrosiers and Weathers 2018).

(e) The leaves of A. annua plants are known to contain a number of classes of secondary metabolites including; artemisinic compounds other than artemisinin (Bhakuni et al., 2001; Brown, 2010; Mesa et al., 2015; Towler and Weathers, 2015; Weathers et al., 2017). Many of these possess varying levels of anti-plasmodial activity, albeit much weaker than in artemisinin. The non-artemisinin, antimalarial compounds affect the survival of parasites via mechanisms that are independent of that for artemisinin, or which determine the availability or activity of artemisinin at its site(s) of action. Some of the metabolites of Artemisia annua characterized for possession of their own kind of antiPlasmodium activity, according to their chemical class, are as follows: artemisinic compounds $=$ arteannuin B, artemisinic acid, dihydroartemisinic acid (Fig. 4; Allen et al., 1997; Suberu et al., 2013; Weathers et al., 2014); coumarin = scopoletin (Fig. 5; Ezcokonkwo and Obidoa, 2001; Ferreira et al., 2010; Malik et al., 2011); flavonoids = artematin, casticin, circilineol, chrysoplenetin, chrysophenol-D, eupatorin, kaempferol, luteolin, myrcetin, quercetin (Fig. 6; Elford et al., 1987; Liu et al., 1992; ChiungSheue et al., 1992; Lehane and Saliba, 2008; Ferreira et al., 2010); phenolic acids = chlorogenic and rosmarinic acids (Fig. 5; de Magaehaes et al., 2012; Suberu et al., 2013; Towler and Weathers, 2014; Daddy et al., 2017); saponins (Fig. 5; Francis et al., 2002); sulfated polysaccharides (Xiao et al., 1996; Clark et al., 1997; Francis et al., 2002; Andrews et al., 2005); terpenes $=$ artemisia alcohol, artemisia ketone, borneol, camphene, camphor, caryophyllene, 1, 8-cineole, germacrene D, limonene, myrcene, nerolidol, $\alpha$-pinene, phytol, sabinene, spathulenol, $\alpha$-terpineol (Fig. 7; Goulart et al., 2004; van Zyl et al., 2006; Grace et al., 2012; Suberu et al., 2013; Bilia et al., 2014; Weathers et al., 2014c; Towler and Weathers, 2015; Daddy et al., 2017). The flavonoids and phenolic acids in general inhibit the cytochrome enzymes, present in liver and intestine, that metabolize artemisinin to deoxyartemisinin, thereby increasing the bioavailability of artemisinin in the blood stream 


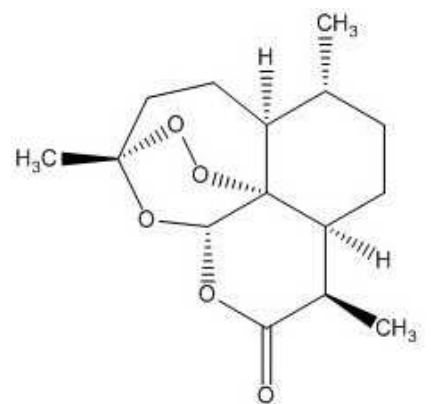

Artemisinin

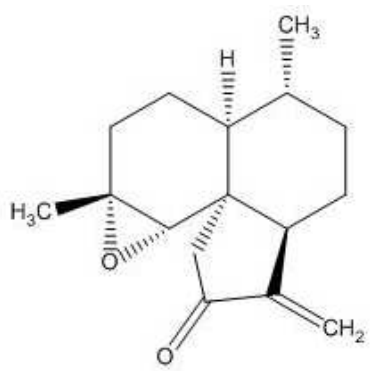

Arteannuin B<smiles>C=C(C(=O)O)C1CC[C@@H](C)C2CCC(C)=CC12</smiles>

Artemisinic acid<smiles>CC1=CC2C(CC1)[C@@H](C)CCC2[C@@H](C)C(=O)O</smiles>

Dihydroartemisinic acid

Fig. 4: Molecular structures of important artemisinic compounds present in the leaves of Artemisia annua<smiles>COc1cc2ccc(=O)oc2cc1O</smiles>

Scopoletin<smiles>CC(C)(C)OC(=O)/C=C/c1ccc(O)c(O)c1</smiles><smiles>COc1c(-c2ccc(O)c(O)c2)oc2cc(O)cc(O)c2c1=O</smiles>

$\mathrm{HO}$<smiles>CCc1ccc(/C=C/C(=O)O[C@@H](Cc2ccc(C)c(CC)c2)C(=O)O)cc1</smiles>

Rosmarinic acid
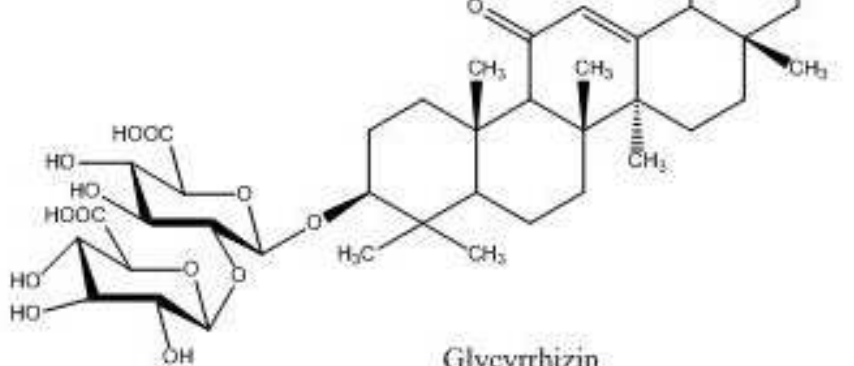

Glycyrrhizin

Fig. 5: Molecular structures of some of the secondary metabolites, representing various classes, present in the leaves of Artemisia annua: scopoletin (coumarin), chlorogenic and rosmaric acids (phenolic acids), glycyrrhizin (saponin) and quercetin-3-methylether (methylated quercetin)

(Elford et al., 1987; Liu et al., 1999; Svensson et al., 1999; Svensson and Ashton, 1999; Sanella et al., 2007; Lehane and Saliba, 2008; Sergent et al., 2009; Choi et al., 2011; de Magalhaes et al., 2012; Suberu et al., 2013; Towler and Weathers, 2015). The methoxylated flavonoids increase the activity of artemisinin against the intra-erythrocytic plasmodia, by blocking the conversion of heme bound to artemisinin to hemozoin, such that there is an enhancement in the release of free radicals from the clearance of the peroxide bridge and eventually in the 
<smiles>COc1cccc(-c2cc(=O)c3c(O)c(OC)c(OC)cc3oc2=O)c1</smiles>

Artemetin

Casticin

Circilineol<smiles></smiles>

Eupatorin<smiles>O=c1c(O)c(-c2ccc(O)cc2)oc2cc(O)cc(O)c12</smiles>

Kaempferol<smiles>O=c1c(O)c(-c2ccc(O)c(O)c2)oc2cc(O)cc(O)c12</smiles>

Quercetin<smiles>O=c1cc(-c2ccc(O)c(O)c2)oc2cc(O)cc(O)c12</smiles>

Luteolin<smiles>O=c1c(O)c(-c2cc(O)c(O)c(O)c2)oc2cc(O)cc(O)c12</smiles>

Myricetin

Fig. 6: Molecular structures of some of the important flavonoids present in the leaves of Artemisia annua

killing of parasites (Rodriguez et al., 1972; Elford, 1987; Bilia et al., 2002 and 2008). The finding, that cytochrome enzymes, which metabolize artemisinin to deoxyartemisinin (Whirl-Carrillo et al., 2012) in the liver of the infected animals, are suppressed by flavonoids and phenolic acids was indicated in an animal- experiment by Weathers et al. (2014b). Separate batches of mice infected with $P$. chabaudi were fed with pure artemisinin and with artemisinin in $A$. annua dry leaves @ 100mg/kg body weight and monitored for $2 \mathrm{~h}$ for the presence of artemisinin and deoxyartemisinin in the blood stream. In mice fed with pure artemisinin, the 
<smiles>C=C(CO)[C@H]1CC[C@@H](C)C2CCC(C)=CC21</smiles>

Artemisinin alcohol<smiles>C=C1CCC=C(C)CCC2C1CC2(C)C</smiles>

Caryophyllene<smiles>C=CC(C)(C)C(=O)C=C(C)C</smiles>

Artemisia ketone

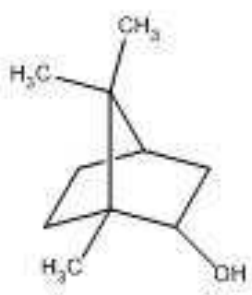

Borneol

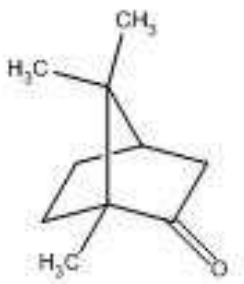

Camphor

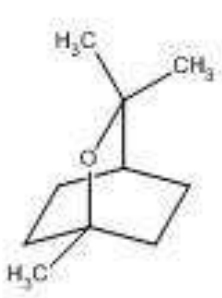

1,8-Cineole<smiles>C=C1C=C[C@@H](C(C)C)CC/C(C)=C\CC1</smiles>

Germacrene D<smiles>C=C(C)[C@H]1CC=C(C)CC1</smiles>

Limonene<smiles>C=CC(=C)CCC=C(C)C</smiles><smiles>C=C1CC[C@@]2(C(C)C)C[C@H]12</smiles>

Sabinene<smiles>CC1=CCC(C(C)(C)O)CC1</smiles>

$\alpha$ - Terpineol

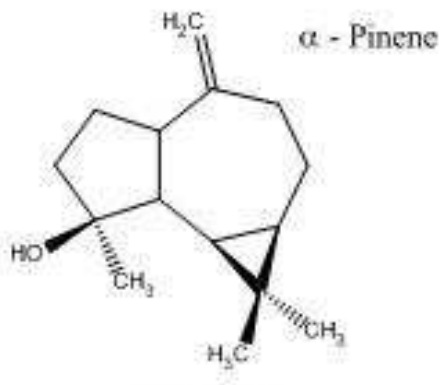

Spathulenol

Fig. 7: Molecular structures of some of the terpenes present in the leaves of Artemisia annua

drug was detectable in the blood only after 60 min, whereas, artemisinin content in the blood constantly increased over the 120 min period in mice fed with artemisinin in $A$. annua dry leaves. In the leaf-fed mice, the content of deoxyartemisinin in the blood stream was much lesser than that in pure artemisinin-fed mice.

(f) ALT was shown to be effective against artemisinin resistant malarial infections and its 
treatment resilient to resistance development in the animal model systems (Elfawal et al., 2015). Administration of a single oral dose of $A$. annua dry leaves ( $24 \mathrm{mg}$ artemisinin/kg body weight) to rodents infected with artemisinin resistant $P$. yoelli cured their parasitaemia, whereas, an equivalent dose of pure artemisinin proved to be ineffective on corresponding animals. It was further shown that the stable resistance to $A$. annua dry leaf treatment, in $P$. chabaudi infected mice occurred 2.7 times slower than acquirement of resistance to pure artemisinin. Achievement of resistance to dry A. annua leaf treatment in $P$. chabaudi infected mice was found to be 1.6 times lower than that for the treatment with artesunate + mefloquine (ACT).

(g) The clinical use of ALT treatment on human patients with severe Pf malaria in the Democratic Republic of Congo proved the efficacy of ALT (Daddy et al., 2017). For ALT treatment, tablets of $500 \mathrm{mg}$ weight, each containing $5.5 \mathrm{mg}$ artemisinin, were prepared by compressing powdered dry leaves of Anamed-A3 variety of $A$. annua. The patients administered with the ALT treatment were 6 males and 12 females, of 14 months to 60 years of age, whose malaria did not get cured, neither with artemether + lumefantrine, nor with intravenous artesunate treatment. The malaria patients had entered the severe phase which included such symptoms as loss of consciousness, convulsions, frustration, shock, respiratory distress, pulmonary edema, bleeding, gastric distress and jaundice. Among the patients, the adults were administered one tablet twice daily for 5 days, children of $5-15 \mathrm{~kg}$ body weight and 15-30 kg body weight, were respectively given quarter and half tablet twice daily for 5 days, and those in coma or too young to swallow tablets, the tablet-dose was crushed, mixed with water and delivered via nasogastric tube. All the patients got cured of their malarial disease and there were no adverse side effects. In ALT treatment on another set of patients, rectal administration of dried pulverized leaves of Artemisia annua was found effective in curing Pf malaria (Abolaji et al., 2016). More extensive studies are needed that will cover 28 days of follow up after treatment with ALT.
From the evidence described above, about the roles of diverse phytochemicals present in the leaves of $A$. annua in augmenting the inhibitory/lethal effects of artemisinin in ALT on infections of Plasmodium species on animal model systems and about clinical efficacy and safety of ALT on human malaria patients, it is possible to conclude that ALT is an inexpensive but safe and effective option for treating acute and severe malaria. Since multiple secondary metabolites with independent lethal mode of action on malarial parasite are involved in the efficacy of ALT, it is possible to further conclude that it will take considerable time period before any resistance evolves against ALT treatment in malarial parasites or via it against artemisinin. It has been advised that safety of ART treatment in pregnant women be evaluated and that nausea resulting from oral intake of dry leaf tablets may be controlled by encapsulation or use of anthelmentics or sweet substances (Yarnell, 2014). Should there be recrudescence, the ALT treatment may be repeated or alternatively a triple ACT treatment be given.

\section{ALT: Establishment of the Compositional Consistency of Tablets}

Like for pharmaceuticals, stringent control over the quality of $A$. annua dry leaf tablets, during their manufacturing process, is essential for ALT's inclusion in the first line antimalarial therapeutics. To achieve this objective in practice, all individual steps of the process must be standardized. To obtain leaves of high artemisinin content, only the identified genotypes of $A$. annua should be grown under consistent and specified cultivation conditions (cultivation_of Artemisia_in_Africa_and_Asia.pdf; Ferreira et al., 1997; Kumar and Srivastava, 2005). To retain the secondary metabolites in high concentrations, the harvested shoots of field grown plants must be dried under clean and ambient conditions (Ferreira et al., 1992; Laughlin, 2002) to retain the secondary metabolites present in them in high concentrations. From the dry shoots, leaves are to be mechanical separated from stem on clean surface, the dry leaves produced from different fields should be homogenized, sieved, pulverized using a blade cutter or equivalent instrument, characterized and converted into tablets of standard weight, size and content of artemisinin and a few flavonoids and terpenes, under hygienic conditions (Weathers and Towler, 2014; Weathers et 
al., 2014a).

The A. annua crops can be cultivated in temperate and sub-tropical agroenvironments, such as those available in the countries of central and southern Europe, Central Asia, Southeast Asia, South Asia, East Africa, South America and in Australia. Several genetically improved and bred varieties of wide adaptability, whose leaves upon drying contain 0.7 to $1.2 \%$ artemisinin, are readily available, including Anamed (A3), Jeevanraksha, Arogya and Sanjeevani (de Magalhaes et al., 1997; Kumar et al., 1999; Delabays et al., 1993 and 2001; Ferreira et al., 2005; Kumar and Srivastava, 2005; Simonnet et al., 2008; Paul et al., 2010; Gupta et al., 2016). Besides, several to many seed industry bred varieties of $A$. annua are also available.

A. annua is a short day-flowering, openpollinated annual shrubby species that completes its life cycle in upto one year time. The sowing and harvesting times of $A$. annua crops to obtain high quality produce of leaves have been prescribed according to the agro-climates of country-wise geographical locations of cultivation and variety(ies) (Ferreira et al., 1992 and 1994; Laughlin, 1994 and 2002; Ram et al., 1997; Gupta et al., 2002; Kumar et al., 2002 and 2004; de Magalhaes et al., 2004; Brisibe et al., 2009; Luo et al., 2009; Goel et al., 2011; Jiang et al., 2013; Pop et al., 2017). The nursery grown plants of 1 month or more age are transplanted in fields@20-70 thousand plants/ ha, depending on the plant architecture and average field duration of plant population of the variety used. Nursery plants are raised by spreading the seeds on a wet soil surface, in a farmyard manure fertilized field. The amount of seeds required for planting 1 ha of crop is $3-5 \mathrm{~g}$. Fields of sandy to sandy loam soil type are used and fertilized with manure and fertilizers @ N:P:K::60:40:40 kg/ha. The transplanted $A$. annua crop, to produce dry leaves for ALT, is harvested before flowering occurs on plants. The plant shoots are dried at temperatures $<40^{\circ} \mathrm{C}$, in field, under shade or in specially designed temperature controlled chambers. The desirable moisture content in the dried leaves is $10-12 \%$. Dry leaves are stored and transported in the form of large blocks by compressing leaves in moulds.

Artemisia annua has been in commercial cultivation by farmers in India for more than 15 years, under the public-institution assisted farmer-company partnerships (Fig. 8; Kumar et al., 2015). In recent years, such farmer-company partnerships have covered $2500 \mathrm{~h} / \mathrm{y}$, largely in the North-West India and in this region preponderantly in the Indo-Gangetic plains area. According to the agro-climate of the IndoGangetic plains, the most suitable time for the sowing of nursery is 15 December to 15 January. Seedlings are transplanted into the fields vacated by potato crops between 20 February and 1 March. This summer crop of A. annua is harvested between May 28 and June 5 (several weeks before the onset of monsoon rains) and shoots are dried under shaded conditions. Alternatively or additionally, the plants growing in nursery are transplanted in fields vacated by wheat crop from 15 May onwards, and the resulting crop is harvested between 21 September and 1 October (after the withdrawal of monsoon rains and with the
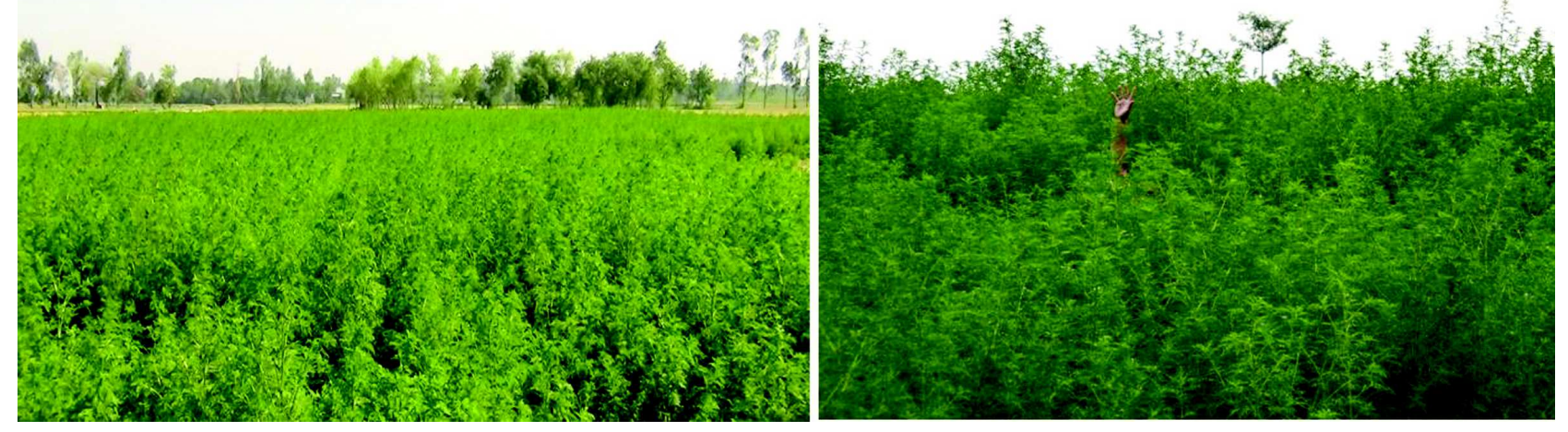

Fig. 8: Artemisia annua cv Sanjeevani crops in farmer's fields in the village Shivpura of district Unnao in the state Uttar Pradesh of the Indo-Gangetic plains area of India [Pictures shared by Sanjay Kumar of CIMAP, Lucknow; Kumar et al., 2015] 
onset of inflorescence development, but before flowering occurs). The autumn crop is dried in temperature controlled chambers. The yield of dry leaves, respectively, from the summer and autumn harvested crop is 2.5 and $3.5 \mathrm{~T} / \mathrm{ha}$, with 0.8 to $1.2 \%$ artemisinin content, depending on the variety used; highest levels of ART (1-1.4\%) are present in the leaves harvested from crops of Sanjeevani variety (Sanjay Kumar, Ramesh Srivastava and Anil Gupta, personal communication).

Need is felt internationally for new genotypes of $A$. annua and for methodologies of plant population propagation, such that the individual plants under cultivation have the same genotype or largely similar genotypes. Since $A$. annua is an open pollinated crop, individual plants in populations of its registered varieties Anamed (A3), Jeevanraksha, Sanjeevani and others demonstrate phenotypic differences arising from segregation of alleles of thousands of genes which are present in heterozygous condition. A genomic study has confirmed presence of heterozygosity at a large number of protein coding genes, amongst 63226 genes identified in A. annua (Shen et al. 2018). The quality of dry leaf tablets from any available variety is the result of an average phenotype of its cultivated populations. In the future it is desirable to have ALT tablets from plants of a single genotype. There are several possibilities to pursue this aim. One of these is to develop elite inbred lines through selfing in existing varieties for 6 or more generations. The seeds of chosen inbred line will be always produced in isolation. Second, F1 hybrids of two selected inbred lines, selected for heterosis, may be chosen for cultivation. Again, F1 seeds will be produced from co-cultivation in isolation of the parental inbred lines whose own seeds will be produced in isolation. Special genotypes, an important one being photo-period independent early flowering, could be developed in the background of chosen singular genotype(s). When suitable genotype(s) have become available for mono-genotype-culture, an alternative method to produce planting material on a mass scale could be the deployment of micro-propagation procedures (Mathur and Kumar, 1996; Paul et al., 2012; Gopinath et al., 2014; Fei and Weathers, 2015, 2016). Any one selected plant from Jeevanraksha, Sanjeevani or Anamed (A3) could become a clonal variety with the use of micropropagation for genotype multiplication.

\section{Cost-effectiveness of ALT Treatment}

The ALT treatment in comparison to ACT treatment is highly cost effective. In the Indo-Gangetic plains area, the cost of cultivation, harvesting and processing of harvested shoots to obtain dry leaves of $A$. annua var Jeevanraksha, Arogya or Sanjeevani (all genetically related), and profit for farmers, under the farmer-private company partnership scheme, for two hectares of crop yield of 50 tons of dry leaves is Rs. 2,00,000 (or $\sim$ US $\$ 3,500$ ). The cost of producing 10 million tablets of $500 \mathrm{mg}$ dry leaves each can therefore be speculated as $\sim$ Rs 5,00,000 (or $\sim$ US\$ 8500 ). Considering the expenditure of all kinds on supply chain of ALT tablets, the cost of a "10 tablets treatment" of an adult is estimated as less than Rs 1 (or less than US Cents 17). The ALT treatment in India will be at least 60 to 150 fold less costly than an ACT treatment. It is possible to conclude that large scale adoption of ALT treatment as advised above can tremendously advance the aim of WHO and 97 malaria endemic countries, including India, to significantly reduce or eliminate the burden of malaria by 2030 (www.rollbackmalaria.org/about-rbm/aim2016-2030; nvbdcp.gov.in > Doc $>$ National-frameworkfor-malaria-elimination-in-India-2016-2030). ALT capsules have the added advantage of use as suppositories.

\section{Possibilities of Using ALT Beyond Malaria}

A variety of disease conditions in humans and livestock are known to respond curatively to artemisinic-, terpenoid-, and flavonoid-compounds present in $A$. annua leaves. There is thus a strong possibility that ALT tablets may prove to be of therapeutic value against many diseases beyond malaria. From a search of the enormous body of publications on the subject of artemisinin (including derivatives)- and A. annuatherapeutics, the tables 4 and 5 provide a short list of disease conditions which are controlled by treatment with artemisinin and/or its derivatives (artemisinins), A. annua's dry leaf powder and/or leaf extracts (termed here as artemisannua). The Tables 4 and 5 also summarize some representative robust evidence which demonstrates that many virus-, bacteria-, fungi, protozoa-, and helminths-caused infectious diseases on the one hand and autoimmune-, and digestive systems/metabolic-disorders, and cancers on the other hand are attenuated/prevented by the treatment with artemisinins and artemisannua. 
Table 4: Summarized evidence which shows that Artemisia annua leaf powder and/or leaf extract, artemisinin and/or artemisinin derivatives are inhibitory and putatively curative against a variety of infectious diseases in humans and livestock animals

\begin{tabular}{llllll}
\hline S.No.Disease(s) & $\begin{array}{l}\text { Causal } \\
\text { infectious } \\
\text { organism/ } \\
\text { agent }\end{array}$ & Host & $\begin{array}{l}\text { Nature } \\
\text { of } \\
\text { study }\end{array}$ & $\begin{array}{l}\text { Therapeutic } \\
\text { test material(s)/ } \\
\text { compound(s) } \\
\text { used }\end{array}$ & Observation(s) \\
& & & Reference(s) \\
& & & &
\end{tabular}

(A) Virus caused:

1 Hepatitis B Hepatitis B virus Hep.G2/2.2.15 and artesunate (HBV) cell line and artesunate inhibited viral replication

Romero et al. (2005) without causing cytotoxicity

2 Hepatitis C Hepatitis

Human derived In vitro Artemisinin $\mathrm{C}$ virus

$\mathrm{HuH}-2$ cell line (HCV)

3 Cytome- Human Human fibroblast In vitro Artesunate galovirus cytome- cells galovirus Human In vivo As above

4 Herpes Human Cultured human In vitro As above virus herpes cells virus $6 \mathrm{~A}$ (HHC-6a)

Viral replication was inhibited; this effect was potentiated by iron donated by hemin, without cytotoxicity

Viral replication was inhibited, very strongly in the presence

Viral load was reduced of iron, without toxicity

Viral early and late gene expression and replication was inhibited and thereby viral multiplication was arrested

Kaptein et al. (2006)

Shapiro et al. (2008)

Milbrandt et al. (2009)

Paeshuyse et al. (2006)

(B) Bacterial caused:

5 Tubercu- Mycobaclosis terium

MGI 960

In vitro As above

A single dose strongly inhibited bacterial growth

Choi (2017) tuberculo- Ogawa slant sis $\mathrm{H} 37 \mathrm{Rv}$ medium assay As above Sprague Dawley In vivo As above rats

measured 21 days after treatment

$3.5 \mathrm{mg} / \mathrm{kg}$ dose a day for 4 weeks As above cured the rats of infection without causing toxicity

(C) Fungus caused:

7 Aspergi- Aspergillus Fungus In vitro Artemisinin llosis fumigatus

The drug killed the fungus by

Gautam et al. (2011) targetting fungal oxidative phosphorylation and cell wall and ergosterol synthesis pathways

\section{(D) Protozoan caused:}

a) Acantha- Acanthamoebiasis moeba

Cultured trophozoites

In vitro Artemether

Amoebae were killed

Deng et al. (2015) castellani (free living amoeba)

In vitro Artemisia annua Amoebae were killed leaves- water, castellani 309 and Ac32

As above alcohol or chloroform extract

$\mathrm{BALB} / \mathrm{C}$ mice In vivo As above (Mus musculus)
As compared to untreated infected mice, the treated infected mice survived for 2 to 4 fold longer time period 


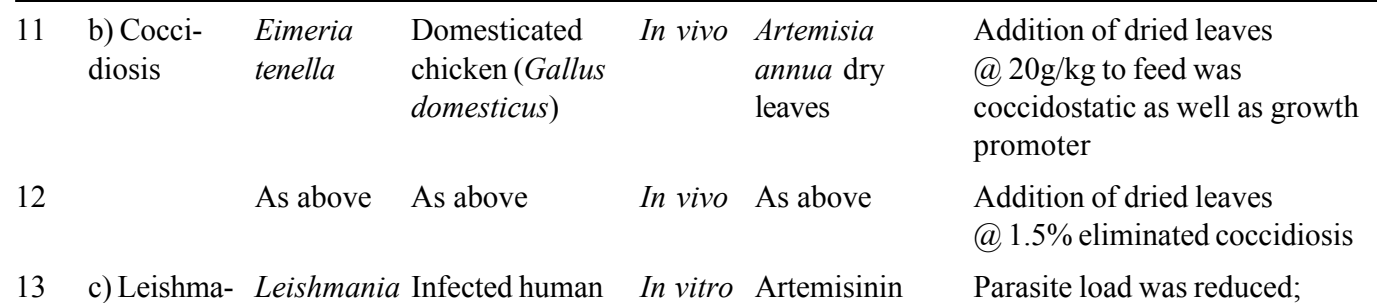
niasis donovani macrophages the anti-leishmanial activity

(Visceral was via apoptosis of parasites infection)

Brisbe et al. (2008);

Bosselman and

Gylling (2013)

Dragan et al. (2014)

Sen et al. $(2007 \& 2010)$

As above $\mathrm{BALB} / \mathrm{C}$ mice In vivo Leaves and seeds Parasite load decreased on of Artemisia account of apoptosis of annua or their promastigotes

Mutiso et al. (2011); hexane extract

As above As above

In vivo Essential oil of

leaves of

Intra-peritonial administration of the essential oil reduced the

Islamuddin et al. (2012)

Islamuddin et al. (2014)

liver by $90 \%$ without toxicity to test animals

Administration of the drug loaded nanoparticles reduced the parasite burden and spleenand hepato-megaly

Leishmania As above

In vivo As above

Lesion size was reduced via major induction of apoptosis in (cutaneous infection)

As above As above

In vivo A

Artemisinin promastigotes ointment

Ulcers were healed

As above

Leishmania Infected human In vitro Artemisia annua Amastigotes were inhibited panamensis U-937 macrophage leaf powder (cutaneous cell line infection) without toxicity to macrophages and genotoxicity to lymphocytes

As above $\begin{aligned} & \text { Hamster } \\ & \text { (Mesocricatus } \\ & \text { auratus) }\end{aligned}$
smosis gondii fibroblast (HFF)

(Obligate cells apicomplexan parasite)

As above Kunming CDI, OFI, Mus musculus

Intracellular amastigotes present As above in the ulcers were killed and 5 out of 6 treated hamsters were cured after 30 days treatment with $500 \mathrm{mg} / \mathrm{kg} /$ day

Two patients were cured after 45 days of treatment with $30 \mathrm{~g}$ of leaf powder (666mg/day)

Infected cells killed much like intra-erythrocytic malarial parasites

As above

Gomes et al. (2012) nosomiasis soma brucei

(African the parasite

Akande and Fagbemi (2011); Yimar and Sahu 2016

All three treatments reduced

Sarciron et al. (2000) fection and improved diseased animals sleeping sickness) 


\begin{tabular}{|c|c|c|c|c|c|c|c|}
\hline \multicolumn{2}{|l|}{25} & As above & Rattus rattus & In vivo & As above & $\begin{array}{l}\text { Growth of parasite was arrested } \\
\text { and life span was extended }\end{array}$ & Oluyomi et al. (2009) \\
\hline \multicolumn{2}{|l|}{26} & As above & $\begin{array}{l}\text { Cultured } \\
\text { trypomastigotes }\end{array}$ & In vitro & Artemisinin & $\begin{array}{l}\text { Parasite growth was arrested } \\
\text { and the mechanism of parasitic } \\
\text { killing was like that of intra- } \\
\text { erythrocytic malarial parasites }\end{array}$ & Mishina et al. (2007) \\
\hline \multicolumn{2}{|l|}{27} & $\begin{array}{l}\text { Trypano- } \\
\text { soma cruzi } \\
\text { (Chagas } \\
\text { disease) }\end{array}$ & $\begin{array}{l}\text { Cultured } \\
\text { epimastigotes }\end{array}$ & In vitro & As above & As above & As above \\
\hline \multicolumn{2}{|l|}{28} & As above & $\begin{array}{l}\text { Cultured in } \\
\text { Vero cells } \\
\text { (kidney } \\
\text { epithelial cells } \\
\text { of African green } \\
\text { monkey) }\end{array}$ & In vitro & Artesunate & $\begin{array}{l}\text { All intracellular stages of } \\
\text { parasite were inhibited }\end{array}$ & $\begin{array}{l}\text { Akande and Fagbemi } \\
(2011) \text {; Olivera } \text { et al. } \\
(2015)\end{array}$ \\
\hline \multicolumn{8}{|c|}{ (E) Metazoan caused: } \\
\hline 29 & $\begin{array}{l}\text { a) Schisto- } \\
\text { somiasis }\end{array}$ & \multicolumn{2}{|c|}{$\begin{array}{l}\text { Schistosoma Humans } \\
\text { mansoni } \\
\text { (Helminth } \\
\text { flatworm; } \\
\text { common in } \\
\text { Africa and } \\
\text { South America) }\end{array}$} & In vivo & Artemether & $\begin{array}{l}\text { The drug prevented as well } \\
\text { as reduced the parasite's } \\
\text { infection }\end{array}$ & $\begin{array}{l}\text { Utzinger et al. (2000); } \\
\text { Kaiser and } \\
\text { Utzinger (2007) }\end{array}$ \\
\hline 30 & & As above & $\mathrm{BALB} / \mathrm{C}$ mice & In vivo & $\begin{array}{l}\text { Dihydroar- } \\
\text { temisinin }\end{array}$ & $\begin{array}{l}\text { A single dose of } 300 \mathrm{mg} / \mathrm{kg} \\
\text { was found on } 21 \mathrm{st} \text { day post } \\
\text { infection to have reduced } \\
\text { much of parasite burden }\end{array}$ & Li et al. (2012) \\
\hline 31 & & $\begin{array}{l}\text { Schistosoma } \\
\text { japonicum } \\
\text { (common in } \\
\text { Southeast A }\end{array}$ & $\begin{array}{l}\text { a As above } \\
\text { sia) }\end{array}$ & In vivo & $\begin{array}{l}\text { Artemether, } \\
\text { artesunate and } \\
\text { dihydro- } \\
\text { artemisinin }\end{array}$ & $\begin{array}{l}\text { All were effective; } 200,300 \text { and } \\
400 \mathrm{mg} / \mathrm{kg} \text { drug administered on } \\
20,21 \text { and } 22 \text { day post infection } \\
\text { strongly reduced the parasite load }\end{array}$ & As above \\
\hline
\end{tabular}

References to review type papers: Efferth (2008); Ho et al. (2014); Efferth et al. 2016 ; Muthamiselvan et al. (2016); Yimer and Sahu (2016); Mesa et al. (2017)

Table 4 summarizes results of some studies on the effects of artemisinins and artemisannua on viral, bacterial-, fungal-, protozoan- and helminth-infections, in cell lines in vitro and/or on model animals or humans in vivo. The drugs artemisinin and artesunate have been found to inhibit replication/multiplication of hepatitis causing hepatitis $\mathrm{B}(\mathrm{HBV})$ and $\mathrm{C}(\mathrm{HCV})$ viruses and sore inducing herpes virus and its close relative cytomegalovirus in cultured human cells. The in vitro growth of Mycobacterium tuberculosis (the bacterium which causes tuberculosis in humans), as well as the tubercular bacterial growth in infected mice, has been found to be arrested by artesunate. Addition of artemisinin to the culture of Aspergillus fumigatus (which causes aspergillosis in human) has been observed to stop the growth of fungus.
Artemether and extracts of $A$. annua leaves have proved lethal to in vitro growing Acanthamoeba castellani (a cause of amoebiasis in humans). Treatment of mice infected with Acanthamoeba with water-, alcohol- or chloroform- extract of Artemisia annua leaves was observed to have increased the life span of diseased animals. Feeding of $A$. annua leaves to the broiler chickens infected with Eimeria tenella parasites saved the infected animals from development of coccidiosis disease. Growth of both visceral and cutaneous leishmaniasis causing Leishmania parasites, in human macrophage cultures, was found to be attenuated by the treatment of artemisinin. Analogously, the leishmania infections in model animals were also observed to have been arrested by treatment with artemisinin or A. annua 
Table 5: Curative effect of Artemisia annua leaf extracts, artemisinin or its derivatives on the diseases of human /model animal immune and digestive systems and cancers of various organs

\begin{tabular}{llllll}
\hline S.No. Type of & Organism(s)/ & $\begin{array}{l}\text { Disease } \\
\text { condition: }\end{array}$ & $\begin{array}{l}\text { Therapeutic } \\
\text { agent tested }\end{array}$ & Observation(s) \\
& $\begin{array}{l}\text { system(s) } \\
\text { used for testing } \\
\text { origin/method } \\
\text { by which } \\
\text { induced }\end{array}$ & & Reference (s) \\
& & & \\
\hline
\end{tabular}

\section{A. Autoimmune}

1. Rheumatoid arthritis

2. Crohn's disease Mouse (Inflammatory bowel)

3. Allergenic asthma

4. Lupus

5. Uveitis

\section{B. Digestive system}

6. Obesity

\section{C57BL/6 mouse}

Nutrition rich diet

7. As above

8. Fatty liver

9. Diabetes

10. As above

\section{E. Cancers}

11. Squamous cell Human cells carcinoma of oral cavity
Albino rat

Alloxan

Sprague Dawley As above rats

CB7BL/6J mouse High fat diet

Zebrafish, mouse, Type I rat, human diabetes pancreatic islet impairment

Artemisinin

Artesunate accharide

Boiled water extract of Artemisia annua dry leaves

Artemisia annua leaves

Dehydrated water extract of Artemisia annua leaves

Artemisia annua leaf extract

Artemether

Artemether


12. Pancreatic Human cells cancer

13. As above

14. Hepatocellular Human cancer

15. As above

Mouse

16. Gastric cancer Human cells

17. As above

18. Colorectal cancer

19. Gall bladder As above cancer

20. As above

As above

21. Renal cancer

As above

22. As above

23. Cervical cancer Human xenograft on mouse

Human As above

Human cancer xenograft on mice
PANC-1, Bx Artesunate

Pc-8 and

CFPAC-1

pancreatic

cancer cell

lines and

HL-7702

normal

hepatic cell

line

Panc-1tumor As above xenograft

in mouse

Hep G-2 and As above BWTG-3 cells

Diethyl nitro- As above samine induced tumor in liver

SGC-7901, As above BGC-823 and

AG5 gastric

cancer and

GES-1 normal

cell lives

Human tumor Gastric tumors As above were xenografted on nude mice

Patients As above

GBC-SD and Artemisinin NOZ gall

bladder cancer

cell lines

The xenograft As above of above cancers on

$\mathrm{BALB} / \mathrm{C}$ mice

Renal cell Artesunate

carcinoma

cell lines:

Caki-1, 786-O

and SN12C-

GFP-SR Lu 2

Xenograft of As above 786-o-Luc cells

planted subcutaneously

HPV-39 inhibi- Artemisinin ted cervical cancer cells
The drug caused oncosis-like cell

Du et al. 2010 death multi-fold more on cancer cells than on normal cells

Artesunate caused dose dependent As above tumor regression

Artesunate reduced the cancer cell Vandewynckel viability in a dose dependent manner et al. 2012

Tumor burden was reduced without As above hepatotoxicity

Cancer cells were killed by oncosis Zhou et al. 2013 like process, but there was no significant effect on non-cancerous cells

The treatment regressed the tumors As above without detriment to animals

Administration of $200 \mathrm{mg}$ drug daily Magalhaes et al. for 14 days cured 8 out of 9 patients 2012 ; Krishna et al. 2014

The treatment stopped cell prolife- Jia et al. 2016 ration and caused cell killing by apoptosis

The xenograft growth was inhibited As above by drug treatment

Cancer cells were killed by oncosis Jeong et al. 2015 via ROS generation and ATP depletion

Intra-peritoneal administration of As above the drug repressed the tumor (growth, metastasis and angiogenesis were all inhibited)

The cancerous cells stopped proli- Mondal and ferating and were killed apoptotically Chatterji 2015 by the effect of the drug 
leaf powder. Artesunate was observed to inhibit the Toxiplasma gondii infection of cultured human cells and of mice in vivo. Trypanosomiasis (human African sleeping sickness) like disease caused by Trypanosoma brucci infection in experimental mice and rats was found to have been cured by the artemether treatment. Artemisinin and artesunate treatments given individually inhibited the growth of T. brucci and T. cruzi (the cause of chagas disease in humans) in cultured human cells. Infection in humans and in experimental mice of Schistosoma mansoni as well as $S$. japonicum (both the species are cause of schistosomiasis disease) was observed to get inhibited by the treatment with each of these drugs- artemether, dihydroartemisinin, and artesunate.

A summary of the results of some representative studies on the effects of artemisinins and artemisannua on rheumatoid arthritis, Crohn's disease, asthma, lupus and uveitis (autoimmune disorders), obesity and diabetes (metabolic disorders) and eight kinds of cancers is listed in the table 5. In different studies, artesunate was found to cure/ suppress and relieve symptoms of collagen induced rheumatoid arthritis, Crohn's disease, ovalabumin induced asthma, and lipopolysaccharide induced uveitis, all in model animals. Obesity and fatty liver diseases caused by consumption of high fat/ nutrition diet in experimental animals were found to be cured by treatment with $A$. annua leaf extracts. The $A$. annua leaf extracts also cured alloxan induced diabetes in rats. It was found that artemether treatment, to type 1 diabetic zebrafish, mice and rats and human pancreatic islets, transformed the pancreatic á cells into $\beta$ cells such that insulin synthesis started relieving the type 1 diabetes symptoms. Cells of human cell lines of pancreatic-, hepatocellular-, gastric-, colorectal- and renal- cancer stopped proliferating and got killed by an oncosis- like process upon treatment with artesunate. Also the xenographs of pancreatic-, hepatocellular-, gastric- and renalcancers in animal models were found to regress upon treatment with artesunate. The artemisinin treatment produced analogous results on in vitro and in vivo gall bladder cancer and on in vitro cervical cancer. The experimental findings, that artemisannua controlled obesity and diabetes in model animals strongly suggest ALT as a treatment for these diseases in humans.
Clearly, the above discussion suggests that the mechanisms of biological actions of artemisinins and artemisannua are such that these agents serve as broad spectrum therapeutics so as to cure a variety of human diseases. These observations raise the possibility that perhaps ALT can substitute for artemisinins and artemisannua and ALT could be a therapy for multiple diseases beyond malaria. In view of the above, the need for pilot studies and clinical trials on quality controlled ALT tablets for studying the response of their administration to patients of each of the different non-malarial, as well as malarial diseases, that respond to artemisinins and artemisannua, can not be overemphasized.

\section{Concluding Remarks}

In the approximately last ten years, the incidence of malaria disease was reduced by $20 \%$ and mortality among malaria patients by $30 \%$. This was mainly achieved by use of two-drug ACTs and chloroquine in the treatment, respectively, of falciparum and vivax malaria and by use of primaquine treatment to block the transmission of parasites from humans to mosquitoes (Table 3). However, the falciparum and vivax malarial parasites have developed genetic resistance against a large majority of the approved antimalarial pharmaceuticals in some of their populations in malaria endemic areas, thereby making the drugs ineffective (Table 2). There has been independent development of artemisinin resistance in Southeast Asia and Africa; consequently ACT treatments too have become ineffective in parts of these geographical areas. To meet the challenge of multi-drug resistant falciparum malarial strains, treatment with three-drug ACTs has been advised. This year, a new treatment (ALT) has been added to cure the acute and complicated malaria caused by ACT-resistant falciparum parasites. The ALT treatment comprises of capsules filled with or tablets made from A. annua dry leaf powder, derived from cultivated plants of specific variety(ies) bred for e" $1 \%$ artemisinin content and a combination of other therapeutically active metabolites naturally present. A regimen of two $500 \mathrm{mg}$ leaf powder tablets a day for 5 days was found to cure adults suffering from ACT resistant complicated falciparum malaria that was unresponsive to ACT or iv artesunate (most likely artemisinin resistant). The ALT treatment's malaria curing property has been related to antimalarial 
activities of artemisinin, several other artemisinic compounds, many terpenes and flavonoids and other types of molecules present in the dry A. annua leaves. ALT is safe and seems resilient against artemisinin drug resistance development. The cost of an ALTtreatment was estimated to be about 100 fold lower than that of an ACT-treatment. Extensive putative use of ALT has gained importance since a recent policy statement of WHO (September 10, 2017) emphasizes on the importance of affordability for everyone of safe, efficacious and quality medical products (http://odishatv.in/health/afforabilitymedicine-who-wants-bold-steps-237875/). The ALT, besides being an efficacious antimalarial treatment has properties which raise possibilities of its multirepurposement as a treatment against all those diseases which respond curatively to artemisinin, its derivatives and A. annua leaf powder or its extracts. This list

\section{References}

Abraham G (2017) Malaria in pregnancy: is artemisinin based treatment safe Evidence based Med 15 63-65

Abolaji G T, Olooto F M and Williams F E (2016) Development of value added tea bags and capsules of Artemisia Annua Anamed (A3) whole plant for malaria treatment Agrosearch 16 69-73

Achan J, Talisuna A O, Erhart A, Yeka A, Tibenderana J K, et al. (2011) Quinine, an old anti-malarial drug in a modern world: role in the treatment of malaria Malar J10 144

Achan J, Tibenderana J K, Kyabayinze D, Wabwire Mangen F, Kamya M R, et al. (2009) Effectiveness of quinine versus artemether-lumefantrine for treating uncomplicated falciparum malaria in Ugandan children: randomised trial BMJ 339 b2763-b2763

Agarwal A, McMorrow M, Onyango P, Otieno K, Odero C, et al. (2013) A randomized trial of artemether-lumefantrine and dihydroartemisinin-piperaquine in the treatment of uncomplicated malaria among children in western Kenya Malar J12 254

Agarwal M, Bhowmick K, Shah K, Krishnamachari A and Dhar S $\mathrm{K}$ (2017) Identification and characterization of ARS-like sequences as putative origin(s) of replication in human malaria parasite Plasmodium falciparum FEBS J 284 26742695

Akande F and Fagbemi B (2011) In vivo and in vitro effects of artemisinin group of drugs on trypanosomosis in mice $J$ Nat Sci Eng Tech 10 73-80 includes diseases as diverse as hepatitis, tuberculosis, leishmaniasis, toxoplasmosis, trypanosomiasis, schistosomiasis, asthma, rheumatoid arthritis, diabetes, and cancers of various body organs. There is now an urgent need for (a) further evaluation of artemisinin efficacy against several of the listed diseases in vivo models, and (b) pilot studies and clinical trials to attest ALT treatment for varied malaria and diseases beyond malaria for which artemisinin efficacy has been experimentally established, for the benefit of billions of patients of above listed diseases.

\section{Acknowledgements}

Authors are grateful to the directors of NIPGR, NBRI and IICT for the facilities and to Indian National Science Academy for SK's association with it as an honorary emeritus scientist.

Al-Zaydani I A, Al-Hakami A, Kumar A, Abdalla S A, Otaif M, et al. (2016) Severe unresolving Plasmodium falciparum malaria following artemisinin combination therapy: Emergence of drug resistance in Saudi Arabia Indian JMed Microbiol 34 553-557

Allen P C, Lydon J and Danforth H D (1997) Effects of components of Artemisia annua on coccidia infections in chickens Poult Sci 76 1156-1163

Amaratunga C, Lim P, Suon S, Sreng S, Mao S, et al. (2016) Dihydroartemisinin-piperaquine resistance in Plasmodium falciparum malaria in Cambodia: A multisite prospective cohort study Lancet Infect Dis 16 357-365

Amato R, Lim P, Miotto O, Amaratunga C, Dek D, et al. (2017) Genetic markers associated with dihydroartemisininpiperaquine failure in Plasmodium falciparum malaria in Cambodia: a genotype-phenotype association study Lancet Infect Dis 17 164-173

Amato R, Miotto O, Woodrow C J, Almagro-Garcia J, Sinha I, et al. (2016) Genomic epidemiology of artemisinin resistant malaria Elife 5 e 08714

Andrews K T, Klatt N, Adams Y, Mischnick P and SchwartzAlbiez R (2005) Inhibition of chondroitin-4-sulfatespecific adhesion of Plasmodium falciparum-infected erythrocytes by sulfated polysaccharides Infect Immun 73 4288-4294

Antinori S, Corona A, Castelli A, Rech R, Borghi B, et al. (2017) Severe Plasmodium falciparum malaria in the intensive care unit: A 6-year experience in Milano, Italy Travel Med 


\section{Infect Dis 17 43-49}

Antony H A and Parija S C (2016) Antimalarial drug resistance: An overview Trop Parasitol 6 30-41

Anvikar A R, Shah N, Dhariwal A C, Sonal G S, Pradhan M M, et al. (2016) Epidemiology of Plasmodium vivax malaria in India Am J Trop Med Hyg 95 108-120

Anyanwu P E, Fulton J, Evans E and Paget T (2017) Exploring the role of socioeconomic factors in the development and spread of anti-malarial drug resistance: a qualitative study Malar J16 203

Ariey F, Witkowski B, Amaratunga C, Beghain J, Langlois A-C, et al. (2014) A molecular marker of artemisinin-resistant Plasmodium falciparum malaria Nature 505 50-55

Ashley EA, Recht J and White N J (2014b) Primaquine: the risks and the benefits Malar $J 13418$

Ashley E A, Dhorda M, Fairhurst R M, Amaratunga C, Lim P, et al. (2014a) Spread of artemisinin resistance in Plasmodium falciparum malaria NEngl J Med 371 411-423

Auparakkitanon S, Chapoomram S, Kuaha K, Chirachariyavej T and Wilairat P (2006) Targeting of hematin by the antimalarial pyronaridine Antimicrob Agents Chemother 50 2197-2200

Ayubu M B and Kidima W B (2017) Monitoring compliance and acceptability of intermittent preventive treatment of malaria using sulfadoxine pyrimethamine after ten years of implementation in Tanzania Malar Res Treat 2017 1-5

Baek H K, Shim H, Lim H, Shim M, Kim C K, et al. (2015) Antiadipogenic effect of Artemisia annua in diet-inducedobesity mice model J Vet Sci 16 389-396

Baird J K and Hoffman S L (2004) Primaquine therapy for malaria Clin Infect Dis 39 1336-1345

Baird J K, Valecha N, Duparc S, White N J and Price R N (2016) Diagnosis and treatment of Plasmodium vivax malaria $\mathrm{Am}$ J Trop Med Hyg 95 35-51

Barber B E, William T, Grigg M J, Menon J, Auburn S, et al. (2013) A prospective comparative study of Knowlesi, falciparum, and vivax malaria in sabah, Malaysia: High proportion with severe disease from plasmodium knowlesi and plasmodium vivax but No mortality with early Referral and artesunate therapy Clin Infect Dis 56 383-397

Barber B E et al. (2017) World malaria report: time to acknowledge Plasmodium knowlesi malaria Malar J16 135

Bassat Q and Menéndez C (2017) Dihydroartemisininpiperaquine: If it works for control, can we use it for elimination? The Lancet Inf Dis 17 121-122

Bediako A et al. (2011) Pharmacokinetics of amodiaquine after a single over dose in Cohanian children with uncomplicated malaria $J$ Pharma Sci \& Res 3 1420-1426

Bensky D and Barolet R (1990) Chinese Herbal Medicines: Formulas and Strategies. Eastland Press, Seatle, USA

Beshir K, Sutherland C J, Merinopoulos I, Durrani N, Leslie T, et al. (2010) Amodiaquine resistance in Plasmodium falciparum malaria in Afghanistan is associated with the pfcrt SVMNT allele at codons 72 to 76 Antimicrob Agents Chemother 54 3714-3716

Bethell D, Se Y, Lon C, Socheat D, Saunders D, et al. (2010) Dose-dependent risk of neutropenia after 7-day courses of artesunate monotherapy in Cambodian patients with acute Plasmodium falciparum malaria Clin Infect Dis $\mathbf{5 1}$ e105-114

Bhakuni R, Jain D, Sharma R and Kumar S (2001) Secondary metabolites of Artemisia annua and their biological activity Curr Sci 80 35-48

Bilia A R, Lazari D, Messori L, Taglioli V, Temperini C and Vincieri F F (2002) Simple and rapid physico-chemical methods to examine action of antimalarial drugs with hemin: Its application to Artemisia annua constituents Life Sci 70 769-778

Bilia A R, Sannella A R, Vincieri F F, Messori L, Casini A, Gabbiani C, Severini C and Majori G (2008) Antiplasmodial effects of a few selected natural flavonoids and their modulation of Artemisinin activity Nat Prod Commun 3 1999-2002

Bilia A R, Santomauro F, Sacco C, Bergonzi M C and Donato R (2014) Essential oil of artemisia annua L.: An extraordinary component with numerous antimicrobial properties Evidence-Based Complement Altern Med 2014

Bisland E, van Vliet L, Williams K, Feltham J, Carrasco M P, Fotoran W L, et al. (2018) Plasmodium dihydrofolate reductase is a second enzyme target for the antimalarial action of triclosan Sci Rep $\mathbf{8}$ Article number 1038

Boggild A K, Parise M E, Lewis L S and Kain K C (2007) Atovaquone-proguanil: Report from the CDC expert meeting on malaria chemoprophylaxis Am J Trop Med Hyg 76 208-223

Bosselmann A S and Gylling M (2013) Economic potential of a Danish production of Artemisia annua based feed additives for broilers. Frieleriksbey: Department of Food and Resource Economics, University of Copenhegan. (IFRO report; No. 224) IFRO_Report_224 pdf

Bousema T and Drakeley C (2011) Epidemiology and infectivity of Plasmodium falciparum and Plasmodium vivax gametocytes in relation to malaria control and elimination Clin Microbiol Rev 24 377-410

Brasil P, Zalis M G, de Pina-Costa A, Siqueira A M, Júnior C B, Silva S, Areas A L L, Pelajo-Machado M, et al. (2017) 
Outbreak of human malaria caused by Plasmodium simium in the Atlantic Forest in Rio de Janeiro: A molecular epidemiological investigation Lancet Glob Health 5 e1038e1046

Briolant S, Fusaï T, Rogier C and Pradines B (2008) Tetracycline antibiotics in malaria Open Trop Med J1 31-46

Brisibe E A, Umoren U E, Brisibe F, Magalhaes P M, Ferreira J P S et al. (2009) Nutritional characterization and antioxidant capacity of different tissues of Artemisia annua Food Chemist 115 1240-1246

Brisibe E A, Umoren U E, Owai P U and Brisibe F (2008) Dietary inclusion of dried Artemisia annua leaves for management of coccidiosis and growth enhancement in chickens African Journal of Biotechnology 7 4083-4092

Brown G D (2010) The biosynthesis of artemisinin (Qinghaosu) and the phytochemistry of Artemisia annua L. (Qinghao) Molecules 15 7603-98

Brown H W (1967) Malaria parasites and other haemosporidia JAMA 201336

Burkhardt D, Wiesner J, Stoesser N, Ramharter M, Uhlemann A C, et al. (2007) Delayed parasite elimination in human infections treated with clindamycin parallels "delayed death" of Plasmodium falciparum in vitro Int J Parasitol 37 777-785

Cairns M, Cisse B, Sokhna C, Cames C, Simondon K, et al. (2010) Amodiaquine dosage and tolerability for intermittent preventive treatment to prevent malaria in children Antimicrob Agents Chemother 54 1265-1274

Caldarelli SA, Hamel M, Duckert J F, Ouattara M, Calas M, et al. (2012) Disulfide prodrugs of albitiazolium (T3/ SAR97276): Synthesis and biological activities J Med Chem 55 4619-4628

Calderón F, Vidal-Mas J, Burrows J, De La Rosa J C, JiménezDíaz M B, et al. (2012) A divergent SAR study allows optimization of a potent 5-HT2c inhibitor to a promising antimalarial scaffold ACS Med Chem Lett 3 373-377

Camargo-Ayala P A, Cubides J R, Niño C H, Camargo M, Rodríguez-Celis C A, et al. (2016) High Plasmodium malariae prevalence in an endemic area of the colombian amazon region $P$ LoS One 11 e0159968

Camus D, Djossou F, Schilthuis H J, Hogh B, Dutoit E, et al. (2004) Atovaquone-proguanil versus chloroquineproguanil for malaria prophylaxis in nonimmune pediatric travelers: results of an international, randomized, openlabel study Clin Infect Dis 38 1716-1723

Carlton J M, Adams J H, Silva J C, Bidwell S L, Lorenzi H, et al. (2008) Comparative genomics of the neglected human malaria parasite Plasmodium vivax Nature 455 757-763
CDC Malaria treatment (United States) (2014) www.cdc.gov/ malaria/diagnosis_treatment/treatment.html.

Chaccour C J, Kobylinski K C, Bassat Q, Bousema T, Drakeley C, et al. (2013) Ivermectin to reduce malaria transmission: a research agenda for a promising new tool for elimination Malar J 12153

Chandira R M, Palanisamy P, Jayakar B and Pasupathi A (2014) Formulation and evaluation of fast dissolving tablets of Artemether and Lumefantrine J Pharm Res 8 1467-1474

Chandra R S, Orazem J, Ubben D, Duparc S, Robbins J and Vandenbroucke P (2013 Creative solutions to extraordinary challenges in clinical trials: methodology of a phase III trial of azithromycin and chloroquine fixed-dose combination in pregnant women in Africa Malar J 12122

Chang C, Lin-Hua T and Jantanavivat C (1992) Studies on a new antimalarial compound: Pyronaridine Trans $R$ Soc Trop Med Hyg 86 7-10

Charman S A, Arbe-Barnes S, Bathurst I C, Brun R, Campbell M, et al. (2011) Synthetic ozonide drug candidate OZ439 offers new hope for a single-dose cure of uncomplicated malaria Proc Natl Acad Sci US A 108 4400-4405

Cheng C, Ho W E, Goh F Y, Guan S P, Kong L R, et al. (2011) Anti-malarial drug artesunate attenuates experimental allergic asthma via inhibition of the phosphoinositide 3kinase/Akt pathway PLoS One 6 e20932

Choi J S, Piao Y J and Kang K W (2011) Effects of quercetin on the bioavailability of doxorubicin in rats: Role of CYP3A4 and P-gp inhibition by quercetin Arch Pharm Res 34 607613

Choi W (2017) Novel pharmacological activity of artesunate and artemisinin: Their potential as anti-tubercular agents J Clin Med 630

Chukwu L C, et al. (2017) Pattern of parasitological response and symptom clearance in patients treated with artemetherlumefantrine combination in the treatment of uncomplicated malaria in Elele, a malaria endemic area in Rivers State Nigeria The FASEB J31 1002

Churcher T S, Sinden R E, Edwards N J, Poulton I D, et al. (2017) Probability of transmission of malaria from mosquito to human is regulated by mosquito parasite density in naïve and vaccinated hosts PLoS Pathog 13 e1006108

Cisse M, Awandare G A, Soulama A, Tinto H, Hayette M-P and Guiguemdé R T (2017) Recent uptake of intermittent preventive treatment during pregnancy with sulfadoxinepyrimethamine is associated with increased prevalence of Pfdhfr mutations in Bobo-Dioulasso, Burkina Faso Malar $J 1638$

Clark D L, Su S and Davidson E A (1997) Saccharide anions as 
inhibitors of the malaria parasite Glycoconj J 14 473-479

Collins W E and Jeffery G M (2005) Plasmodium ovale: Parasite and disease Clin Microb Rev 20 579-592

Cordel H, Cailhol J, Matheron S, Bloch M, Godineau N, et al. (2013) Atovaquone-proguanil in the treatment of imported uncomplicated Plasmodium falciparum malaria: a prospective observational study of 553 cases Malar $J 12$ 399

Cottrell G, Musset L, Hubert V, Le Bras J and Clain J (2014) Emergence of resistance to atovaquone-proguanil in malaria parasites: Insights from computational modeling and clinical case reports Antimicrob Agents Chemother 58 4504-4514

Cowman A F, Galatis D and Thompson J K (1994) Selection for mefloquine resistance in Plasmodium falciparum is linked to amplification of the pfmdr1 gene and cross-resistance to halofantrine and quinine Proc Natl Acad Sci U S A 91 1143-1147

Cowell A N, Istvan E S, Lukens A K, Gomez-Lorenzo M G, Vanaerschot M, Sakata-Kato, et al. (2018) Mapping the malarial parasite druggable genome by using in vitro evolution and chemogenomics Science 359 197-199

Croft A M (2007) Developing safe antimalaria drugs: Key lessons from mefloquine and halofantrine Int J Risk Saf Med 19 153-161

Croft S L, Duparc S, Arbe-Barnes S J, Craft J, Shin C-S, et al. (2012) Review of pyronaridine anti-malarial properties and product characteristics Malar J 11270

Cui L, Mharakurwa S, Ndiaye D, Rathod P K and Rosenthal P J (2015) Antimalarial drug resistance: Literature review and activities and findings of the ICEMR network Am J Trop Med Hyg 93 (Suppl 3) 57-68

Daddy N B, Kalisya L M, Bagire P G, Watt R L, Towler M J and Weathers P J (2017) Artemisia annua dried leaf tablets treated malaria resistant to ACT and i.v. artesunate: Case reports Phytomedicine 32 37-40

Dahl E L, Shock J L, Shenai B R, Gut J, DeRisi J L and Rosenthal P J (2006) Tetracyclines specifically target the apicoplast of the malaria parasite Plasmodium falciparum Antimicrob Agents Chemother 50 3124-3131

Daulay D A P, Trisnawati Y, Lubis S, Pasaribu S, et al. (2011) Comparison of quinine-doxycycline and quinineclindamycin for falciparum malaria in children Paediatrica Indonesia 51 187-191

Davis T M E, Hung T Y, Sim I K, Karunajeewa H A and Ilett K F (2005) Piperaquine: A resurgent antimalarial drug Drugs 65 75-87

de Carvalho G B and de Carvalho G B (2011) Duffy Blood
Group System and the malaria adaptation process in humans Rev Bras Hematol Hemoter 33 55-64

De Magalhães P M, Pereira B, Sartoratto A, De Oliveira J and Debrunner N (1999) New hybrid lines of the antimalarial species Artemisia annua L. Acta Hortic 502 377-381

de Magalhaes P M, Pereira B and Sartoratta A (2004) Yields of antimalarial Artemisia annua L. species. Acta Hort 629, I5H5 Proc XXVI IHC_Future of Medicinal and Aromatic Plants Eds LE 421-424

Delabays N, Collet G and Benakis A(1993) Selection and breeding for high artemisinin (quinghaso) yielding strains of Artemisia annua Acta Hort 330 203-207

Delabays N, Simonnet X and Gaudin M (2001) The genetics of artemisinin content in Artemisia annua L. and the breeding of high yielding cultivars Curr Med Chem 8 1795-1801

Dellicour S, Sevene E, McGready R, Tinto H, Mosha D, et al. (2017) First-trimester artemisinin derivatives and quinine treatments and the risk of adverse pregnancy outcomes in Africa and Asia: A meta-analysis of observational studies PLoS Med 14 e1002290

Delves M, Plouffe D, Scheurer C, Meister S, Wittlin S, et al. (2012b) The activities of current antimalarial drugs on the life cycle stages of plasmodium: A comparative study with human and rodent parasites PLoS Med 9 e1001169

Delves M J, Ramakrishnan C, Blagborough A M, Leroy D, Wells T N C and Sinden R E (2012a) A high-throughput assay for the identification of malarial transmission-blocking drugs and vaccines Int J Parasitol 42 999-1006

Delves M J, Ruecker A, Straschil U, Lelièvre J, Marques S, et al. (2013) Male and female Plasmodium falciparum mature gametocytes show different responses to antimalarial drugs Antimicrob Agents Chemother 57 3268-3274

Deng Y, Ran W, Man S, Li X, Gao H, et al. (2015) Artemether exhibits amoebicidal activity against Acanthamoeba castellanii through inhibition of the serine biosynthesis pathway Antimicrob Agents Chemother 59 4680-4688

Derda M, Hadaœ E, Cholewiñski M, Skrzypczak £, Grzondziel A and Wojtkowiak-Giera A(2016) Artemisia annua L. as a plant with potential use in the treatment of acanthamoebiasis Parasitol Res 115 1635-1639

Desai M, Gutman J, Taylor S M, Wiegand R E, Khairallah C, et al. (2016) Impact of sulfadoxine-pyrimethamine resistance on effectiveness of intermittent preventive therapy for Malaria in pregnancy at clearing infections and preventing low birth weight Clin Infect Dis 62 323-333

Desrosiers M R and Weathers P J (2016) Effect of leaf digestion and artemisinin solubility for use in oral consumption of dried Artemisia annua leaves to treat malaria $J$ 
Ethnopharmacol $190313-318$

Desrosiers M R and Weathers P J (2018) Artenisinin permeability via $\mathrm{CaCo}-2$ cells increases after simulated digestion of Artemisia annua leaves J Ethnopharmacol 210 254-259

Devine A, Parmiter M, Chu CS, Bancone G, Nosten F, et al. (2017) Using G6PD tests to enable the safe treatment of Plasmodium vivax infections with primaquine on the Thailand-Myanmar border: A cost-effectiveness analysis PLoS Negl Trop Dis 11 e0005602

Dhingra V, Rao K V and Narasu M L (1999) Artemisinin: Present status and perspectives Biochemical Education 27 105109

Dicko A, Roh M E, Diawara H, Mahamar A, Soumare H M, et al. (2018) Efficacy and safety of primaquine and methylene blue for prevention of Plasmodium falciparum transmission in Mali: a phase 2, simple-blind, randomized controlled trial The Lancet Infect Disease doi.org/10.1016/S14733099(18)30044-6

Doctor S M, Liu Y, Anderson O G, Whitesell AN, Mwandagalirwa M K, et al. (2016) Low prevalence of Plasmodium malariae and Plasmodium ovale mono-infections among children in the Democratic Republic of the Congo: a population-based, cross-sectional study Malar J 15350

Doerig C, Rayner J C, Scherf A and Tobin A B (2015) Posttranslational protein modifications in malaria parasites $\mathrm{Nat}$ Rev Microbiol 13 160-172

Dondorp A M (2017) New genetic marker for piperaquine resistance in Plasmodium falciparum Lancet Infect Dis $\mathbf{1 7}$ 119-121

Dondorp A M, Fanello C I, Hendriksen I C, Gomes E, Seni A, et al. (2010) Artesunate versus quinine in the treatment of severe falciparum malaria in African children (AQUAMAT): An open-label, randomised trial Lancet 376 1647-1657

Dondorp A M, Nosten F, Yi P, Das D, Phyo A P, et al. (2009) Artemisinin resistance in Plasmodium falciparum malaria N Engl J Med 361 455-467

Dondorp A M, Smithuis F M, Woodrow C and Seidlein L von (2017) How to contain artemisinin- and multidrug-resistant falciparum malaria Trends Parasitol 33 353-363

Dow G S, Gettayacamin M M, Hansukjariya P P, imerbsin R R, Komcharoen S S, et al. (2011) Radical curative efficacy of tafenoquine combination regimens in Plasmodium cynomolgi-infected Rhesus monkeys (Macaca mulatta) Malar J10 212

Drãgan L, Györke A, Ferreira J F, Pop I A, Dunca I, et al. (2014) Effects of Artemisia annua and Foeniculum vulgare on chickens highly infected with Eimeria tenella (Phylum Apicomplexa) Acta Vet Scand $\mathbf{5 6} 22$

Du J-H, Zhang H-D, Ma Z-J and Ji K-M (2010) Artesunate induces oncosis-like cell death in vitro and has antitumor activity against pancreatic cancer xenografts in vivo Cancer Chemother Pharmacol 65 895-902

Duffy C W, Ba H, Assefa S, Ahouidi A D, Deh Y B, et al. (2017) Population genetic structure and adaptation of malaria parasites on the edge of endemic distribution Mol Ecol 26 2880-2894

Duffy S and Avery V M (2012) Development and optimization of a novel 384-well anti-malarial imaging assay validated for high-throughput screening Am J Trop Med Hyg 86 8492

Duffy S and Avery V M (2013) Identification of inhibitors of Plasmodium falciparum gametocyte development Malar $J 12408$

Duke J A (2001) Handbook of phytochemical constituents of CoRAs herbs and other economic plants CRC Press

Dutta G P, Puri S K, Bhaduri A P and Seth M (1989) Radical curative activity of a new 8-aminoquinoline derivative (CDRI 80/53) against Plasmodium cynomolgi $\mathrm{B}$ in monkeys Am J Trop Med Hyg 41 635-637

D $1 / 4$ Alessandro U (2009) Progress in the development of piperaquine combinations for the treatment of malaria Curr Opin Infect Dis 22 588-592

Ecker A, Lehane A M, Clain J and Fidock D A (2012) PfCRT and its role in antimalarial drug resistance Trends Parasitol 28 504-514

Eder M, Farne H, Cargill T, Abbara A and Davidson R N (2012) Intravenous artesunate versus intravenous quinine in the treatment of severe falciparum malaria: a retrospective evaluation from a UK centre Pathog Glob Health 106 181187

Efferth T (2007) Willmar Schwabe Award 2006: Antiplasmodial and antitumor activity of artemisinin - From bench to bedside Planta Med 73 209-309

Efferth T (2017) From ancient herb to modern drug: Artemisia annua and artemisinin for cancer therapy Semin Cancer Biol 46 65-83

Efferth T (2017) Cancer combination therapies with artemisinintype drugs Biochemical Pharmacology 139 56-70

Efferth T, Herrmann F, Tahrani A and Wink M (2011) Cytotoxic activity of secondary metabolites derived from Artemisia annua L. towards cancer cells in comparison to its designated active constituent artemisinin Phytomedicine 18 959-969 
Efferth T, Romero M R, Osman A G, ElSohly M, Wink M, et al. (2016) Expanding the therapeutic spectrum of artemisinin activity against infectious diseases beyond malaria and novel pharmacological developments World $J$ Tradition Clin Med 2 1-23

Efferth T, Romero M R, Wolf D G, Stamminger T, Marin J J G and Marschall M (2008) The antiviral activities of artemisinin and artesunate Clin Infect Dis 47 804-811

Elfawal M A, Towler M J, Reich N G, Golenbock D, Weathers P J and Rich S M (2012) Dried whole plant Artemisia annua as an antimalarial therapy PLoS One 7 e52746

Elfawal M A, Towler M J, Reich N G, Weathers P J and Rich S M (2015) Dried whole-plant Artemisia annua slows evolution of malaria drug resistance and overcomes resistance to artemisinin Proc Natl Acad Sci USA 112 821-826

Elford B C, Roberts M F, Phillipson J D and Wilson R J M (1987) Potentiation of the antimalarial activity of qinghaosu by methoxylated flavones Trans R Soc Trop Med Hyg $\mathbf{8 1}$ 434436

Elmes N J, Nasveld P E, Kitchener S J, Kocisko D A and Edstein M D (2008) The efficacy and tolerability of three different regimens of tafenoquines versus primaquine for postexposure prophylaxis of Plasmodium vivax malaria in south west Pacific Trans Royal Soc Trop Med Hyg 102 10951101

Epstein J E, Paolino K M, Richie T L, Sedegah M, Singer A, et al. (2017) Protection against Plasmodium falciparum malaria by PfSPZ Vaccine JCI Insight 2 e89154

Esu E, Effa E E, Opie O N, Uwaoma A and Meremikwu M M (2014) Artemether for severe malaria Cochrane database Syst Rev 9 CD010678

Eziefula A C, Bousema T, Yeung S, Kamya M, Owaraganise A, et al. (2014) Single dose primaquine for clearance of Plasmodium falciparum gametocytes in children with uncomplicated malaria in Uganda: A randomised, controlled, double-blind, dose-ranging trial Lancet Infect Dis 14130 139

Ezzet F, Van Vugt M, Nosten F, Looareesuwan S and White N J (2000) Pharmacokinetics and pharmacodynamics of lumefantrine (benflumetol) in acute falciparum malaria Antimicrob Agents Chemother 44 697-704

Färnert A, Lindberg J, Gil P, Swedberg G, Berqvist Y, et al. (2003) Evidence of Plasmodium falciparum malaria resistant to antovaquone and proguanil hdrochloride: case reports $B m j$ 326 628-629

Fei L and Weathers P J (2015) From leaf explants to rooted plantlets in a mist reactor In Vitro Cell Dev Biol Plant 51 669-681
Fei L and Weathers P J (2016) From leaf explants to hanging rooted plantlets in a mist reactor Plant Cell Tiss Org Cult 124 265-274

Ferreira J F S and Janick J (1995) Production and detection of artemisinin from Artemisia annua Int Symp Med Aromat Plants 209 41-49

Ferreira J F S, Laughlin J C, Delabays N and de Magalhães P M (2005) Cultivation and genetics of Artemisia annua L. for increased production of the antimalarial artemisinin Plant Genet Resour Charact Util 3 206-229

Ferreira J F S, Luthria D L, Sasaki T and Heyerick A (2010) Flavonoids from Artemisia annua L. As antioxidants and their potential synergism with artemisinin against malaria and cancer Molecules 15 3135-3170

Ferreira J F S, Simon J E and Janick J (2010) Artemisia annual : Botany, Horticulture, Pharmacology. In Horticultural Reviews, pp. 319-71

Fowler R E, Sinden R E and Pudney M (1995) Inhibitory activity of the anti-malarial atovaquone (566C80) against ookinetes, oocysts, and sporozoites of Plasmodium berghei $J$ Parasitol 81 452-458

Francis G, Kerem Z, Makkar H P S and Becker K (2002) The biological action of saponins in animal systems: a review Br J Nutr $\mathbf{8 8} 587-605$

Friedman R and Caflisch A (2009) Discovery of plasmepsin inhibitors by fragment-based docking and consensus scoring Chem Med Chem 4 1317-1326

Gadalla N B, Abdallah T M, Atwal S, Sutherland C J and Adam I (2013) Selection of pfdhfr/pfdhps alleles and declining artesunate/sulphadoxine-pyrimethamine efficacy against Plasmodium falciparum eight years after deployment in eastern Sudan Malar J 12255

Gaillard T, Briolant S, Madamet M and Pradines B (2017) The end of a dogma: the safety of doxycycline use in young children for malaria treatment Malar J16 148

Gaillard T, Madamet M and Pradines B (2015) Tetracyclines in malaria Malar J14 445

Gaillard T, Madamet M, Tsombeng F F, Dormoi J and Pradines B (2016) Antibiotics in malaria therapy: which antibiotics except tetracyclines and macrolides may be used against malaria? Malar $J 15556$

Galatas B, Nhamussua L, Candrinho B, Mabote L, Cisteró P, et al. (2017) In-vivo efficacy of chloroquine to clear asymptomatic infections in mozambican adults: a randomized, placebo-controlled trial with implications for elimination strategies Sci Rep 71356

Gardner M J, Hall N, Fung E, White O, Berriman M, et al. (2002) 
Genome sequence of the human malaria parasite Plasmodium falciparum Nature 419 498-511

Gargano N, Ubben D, Tommasini S, Bacchieri A, Corsi M, et al. (2012) Therapeutic efficacy and safety of dihydroartemisinin-piperaquine versus artesunatemefloquine in uncomplicated Plasmodium falciparum malaria in India Malar $J 11233$

Gatton M L, Martin L B and Cheng Q (2004) Evolution of resistance to sulfadoxine-pyrimethamine in Plasmodium falciparum Antimicrob Agents Chemother 48 2116-2123

Gautam P, Upadhyay S K, Hassan W, Madan T, Srideshmukh R et al. (2011) Transcriptic and proteomic profile of Aspergillus fumigatus on exposure to artemisinin Mycopathologia 172 331-346

Ghaffarifar F, Esavand Heydari F, Dalimi A, Hassan Z M, Delavari $\mathrm{M}$ and Mikaeiloo H (2015) Evaluation of apoptotic and antileishmanial activities of artemisinin on promastigotes and BALB/C mice infected with Leishmania major Iran J Parasitol 10 258-267

Gil J P, Nogueira F, Strömberg-Nörklit J, Lindberg J, Carrolo M, Casimiro C, Lopes D, Arez A P, Cravo P V and Rosário V E (2003) Detection of atovaquone and malarone resistance conferring mutations in Plasmodium falciparum cytochrome b gene (Cyt b) Mol Cell Probes 17 85-89

Global Malaria Progamme (2015) Control and elimination of Plamodium vivax Malaria - A Technical Brief

Goel D et al. (2016) Artesunate-, sulfadoxine-, and pyrimethamineinduced cardiotoxicity BLDE Univ J Health Sci Case Report $154-56$

Goel R, Goel D, Chaudhary S, Sharma V and Kumar S (2011) Cropping of the artemisinin (antimalarial drug) yielding Artemisia annua cultivars, over a ten year period in the agroclimate of north-west India,has not led to the species becoming a weed National Academy Science Letters 34 307-315

Gomes T C, Andrade Júnior H F de, Lescano S A Z and AmatoNeto V (2012) In vitro action of antiparasitic drugs, especially artesunate, against Toxoplasma gondii Rev Soc Bras Med Trop 45 485-490

Goodman C D, Siregar J E, Mollard V, Vega-Rodriguez J, Syafruddin D, et al. (2016) Parasites resistant to the antimalarial atovaquone fail to transmit by mosquitoes Science 352 349-353

Gopalakrishnan A M and Kumar N (2015) Antimalarial action of artesunate involves DNA damage mediated by reactive oxygen species Antimicrob Agents Chemother 59317-325

Gopinath B et al. (2014) In vitro propagation of an important medicinal plant Artemisia annua L. from axillary bud explants Adv Appl Sci Res 5 254-258

Goulart H R, Kimura E A, Peres V J, Couto A S, Duarte F AA and Katzin A M (2004) Terpenes arrest parasite development and inhibit biosynthesis of isoprenoids in Plasmodium falciparum Antimicrob Agents Chemother 48 2502-2509

Grace M H, Lategan C, Graziose R, Smith P J, Raskin I and Lila M A (2012) Antiplasmodial activity of the ethnobotanical plant Cassia fistula Nat Prod Commun 7 1263-1266

Graves P M, Choi L, Gelband H and Garner P (2018) Primaquine or other 8-amino quinolines for reducing Plasmodium falciparum transmission Cochrane Darabase of Syst Rev doi.10.1002/14651858.CD008152.pub5

Graves P M, Gelband H and Ribeiro I (2009) Primaquine for reducing transmission of Plasmodium falciparum malaria Lancet Infect Dis 16 674-684

Grigg M J, William T, Menon J, Barber B E, Wilkes C S, et al. (2016) Efficacy of artesunate-mefloquine for chloroquineresistant Plasmodium vivax malaria in Malaysia: An openlabel, randomized, controlled trial Clin Infect Dis 62 14031411

Gujjar R, E 1 Mazouni F, White K L, White J, Creason S, et al. (2011) Lead optimization of aryl and aralkyl amine-based triazolopyrimidine inhibitors of Plasmodium falciparum dihydroorotate dehydrogenase with antimalarial activity in mice J Med Chem 54 3935-3949

Gupta A, Gupta M M, Srivastava A, Bansal R P, Lal R K, et al. (2016) CIM-Sanjeevani: A high artemisinin yielding population of Artemisia (Artemisia annua) J Med Arom Plant Sci 38 78-83

Gupta A P, Chin W H, Zhu L, Mok S, Luah Y, et al. (2013) Dynamic epigenetic regulation of gene expression during the life cycle of malaria parasite Plasmodium falciparum PLoS Pathog 9 e 1003170

Gupta B, Xu S, Wang Z, Sun L, Miao J, et al. (2014) Plasmodium falciparum multidrug resistance protein 1 ( $p f m r p l)$ gene and its association with in vitro drug susceptibility of parasite isolates from northeast Mynmar J Antimicrob Chemother 89 2110-2117

Gupta S K, Singh P, Bajpai P, Ram G, Singh D, et al. (2002) Morphogenetic variation for artemisinin and volatile oil in Artemisia annua Ind Crops Prod 16 217-224

Gutman J, Kovacs S, Dorsey G, Stergachis A and ter Kuile F O (2017) Safety, tolerability, and efficacy of repeated doses of dihydroartemisinin-piperaquine for prevention and treatment of malaria: a systematic review and meta-analysis Lancet Infect Dis 17 184-193 
Gutman J and Slutsker L (2017) Intermittent preventive treatment with sulfadoxine-pyrimethamine: More than just an Antimalarial? Am J Trop Med Hyg 11 9-10

Guttery D S, Holder AA and Tewari R (2012) Sexual development in plasmodium: Lessons from functional analyses PLoS Pathog 8 e 1002404

Hall N (2012) Genomic insights into the other malaria Nat Genet 44 962-963

Hamilton W L, Claessens A, Otto T D, Kekre M, Fairhurst R M, et al. (2017) Extreme mutation bias and high AT content in Plasmodium falciparum Nucleic Acids Res 45 1889-1901

Harrison T R (1970) Harrison's principles of internal medicine $6^{\text {th }}$ ed, McGraw-Hill, NY

Hatz C, Soto J, Nothdurft H D, Zoller T, Weitzel T, et al. (2008) Treatment of acute uncomplicated falciparum malaria with artemether-lumefantrine in nonimmune populations: a safety, efficacy, and pharmacokinetic study Am J Trop Med Hyg 78 241-247

Helal E G E, et al. (2014) Anti-diabetic effect of Artemisia annua (Kaysom) is alloxan induced diabetic rats Egypt J Hosp Med 57 422-430

Henriques G, Hallett R L, Beshir K B, Gadalla N B, Johnson R E, et al. (2014) Directional selection at the pfmdr1, pfcrt, pfubp1, and pfap2mu loci of Plasmodium falciparum in Kenyan children treated with ACT J Infect Dis 2102001 2008

Herchline T E (2016) Malaria treatment and management emedicine.medscope.com/article/221134-treatmentoverview\#a1

Hii J and Rueda L M (2013) Malaria vectors in the Greater Mekong Subregion: overview of malaria vectors and remaining challenges Southeast Asian J Trop Med Public Health 44 Suppl 1 73-165

Hill D R, Baird J K, Parise M E, Lewis L S, Ryan E T and Magill A J (2006) Primaquine: Report From Cdc Expert Meeting on Malaria Chemoprophylaxis I Am J Trop Med Hyg $\mathbf{7 5}$ 402-415

Ho W E, Cheng C, Peh H Y, Xu F, Tannenbaum S R, et al. (2012) Anti-malarial drug artesunate ameliorates oxidative lung damage in experimental allergic asthma Free Radic Biol Med 53 498-507

Ho W E, Peh H Y, Chan T K and Wong W S F (2014) Artemisinins: Pharmacological actions beyond anti-malarial Pharmacol Ther 142 126-139

Hodel E, Guidi M, Zanolari B, Mercier T, Duong S, et al. (2013) Population pharmacokinetics of mefloquine, piperaquine and artemether-lumefantrine in Cambodian and Tanzanian malaria patients Malar J 12235

Hoglund R M, Adam I, Hanpithakpong W, Ashton M, Lindegardh $\mathrm{N}$, et al. (2012) A population pharmacokinetic model of piperaquine in pregnant and non-pregnant women with uncomplicated Plasmodium falciparum malaria in Sudan Malar J 11398

Hongwen Y and Shouming Z (2002) Chapter 9 In : C. W. Wright, Artemisia, New York, N.Y Taylor and Francis p 148-158

Howes R E, Battle K E, Satyagraha A W, Baird J K and Hay S I (2013) G6PD Deficiency. Global Distribution, Genetic Variants and Primaquine Therapy Adv Parasitol 81 135201

Hsu E (2006) The history of qing hao in the Chinese materia medica Trans R Soc Trop Med Hyg 100 505-508

Huang H, Lu W, Li X, Cong X, Ma H, et al. (2012) Design and synthesis of small molecular dual inhibitor of falcipain-2 and dihydrofolate reductase as antimalarial agent Bioorganic Med Chem Lett 22 958-962

Ikram N K B K and Simonsen H T (2017) A review of biotechnological Artemisinin production in plants Front Plant Sci 81966

ICIPE (2005) Whole leaf Artemisia annua -based antimalarial drug: report on proof-of-concept studies http://bot.ly// lvCHQkH.2005

Ikram N K B K, Kashkovli A B, Peramuna AP, vander Krol A R, Bouwmeester H, et al. (2017) Stable production of the antimalarial drug artemisinin in the moss Physcomitrella patens Front Bioeng Biotechnol 547

Imwong M, Suwannasin K, Kunasol C, Sutawong K, Mayxay M, et al. (2017) The spread of artemisinin-resistant Plasmodium falciparum in the Greater Mekong subregion: a molecular epidemiology observational study Lancet Infect Dis 17 491-497

Islamuddin M, Chouhan G, Want M Y, Tyagi M, Abdin M Z, et al. (2014) Leishmanicidal activities of Artemisia annua leaf essential oil against Visceral Leishmaniasis Front Microbiol 5626

Islamuddin M, Farooque A, Dwarakanath B S, Sahal D and Afrin F (2012) Extracts of Artemisia annua leaves and seeds mediate programmed cell death in Leishmania donovani $J$ Med Microbiol 61(PART12) 1709-1718

Janse CJ, Ponnudurai T, Lensen A H, Meuwissen J H, Ramesar J, et al. (1988) DNA synthesis in gametocytes of Plasmodium falciparum Parasitology 96 1-7

Jeong D E, Song H J, Lim S, Lee S J, Lim J E, et al. (2015) Repurposing the anti-malarial drug artesunate as a novel therapeutic agent for metastatic renal cell carcinoma due to 
its attenuation of tumor growth, metastasis, and angiogenesis Oncotarget 6 33046-33064

Jia J, Qin Y, Zhang L, Guo C, Wang Y, et al. (2016) Artemisinin inhibits gallbladder cancer cell lines through triggering cell cycle arrest and apoptosis Mol Med Rep 13 4461-4468

Jiang X, Zhang H, Wang M, Wang L and Zhang L (2013) Comparison analysis of different parts and geographical origins from southwestern China on artemisinin content of Artemisia annua Curr Trends Technol Sci 2293

Josling G A and Llinás M (2015) Sexual development in Plasmodium parasites: knowing when it's time to commit Nat Rev Microbiol 13 573-587

Kakkilaya B S (2003) Rapid diagnosis of malaria Lab Med 8602 608

Kakuru A, Jagannathan P, Muhindo M K, Natureeba P, Awori P, et al. (2016) Dihydroartemisinin-Piperaquine for the prevention of malaria in pregnancy N Engl J Med 374928 939

Kaptein S J F, Efferth T, Leis M, Rechter S, Auerochs S, et al. (2006) The anti-malaria drug artesunate inhibits replication of cytomegalovirus in vitro and in vivo Antiviral Res 69 60-69

Karunajeewa H A, Reeder J, Lorry K, Dabod E, Hamzah J, PageSharp M, et al. (2006) Artesunate suppositories versus intramuscular artemether for treatment of severe malaria in children in Papua New Guinea Antimicrob Agents Chemother 50 968-974

Kazmin D, Nakaya H I, lee E K, Johnson M J, vander Most R A et al. (2017) Systems analysis of protective immune responses to RTS,S malaria vaccination in humans Proc Natl Acad Sci USA 114 2425-2430

Keating G M (2012) Dihydroartemisinin/piperaquine: A review of its use in the treatment of uncomplicated Plasmodium falciparum malaria Drugs 72 937-961

Keiser J and Utzinger J (2007) Artemisinins and synthetic trioxolanes in the treatment of helminth infections Curr Opin Infect Dis 20 605-612

Kerb R, Fux R, Mörike K, Kremsner P G, Gil J P, et al. (2009) Pharmacogenetics of antimalarial drugs: effect on metabolism and transport Lancet Infect Dis 9 760-774

Kheng S, Muth S, Taylor W R J, Tops N, Kosal K, et al. (2015) Tolerability and safety of weekly primaquine against relapse of Plasmodium vivax in Cambodians with glucose6-phosphate dehydrogenase deficiency BMC Med 13203

Kim K E, Ko K, Heo R W, Yi C O, Shin H J, et al. (2016) Artemisia annua leaf extract attenuates hepatic steatosis and inflammation in high-fat diet-fed mice J Med Food 19
290-299

Kisalu N K, Idris A H, Weidle C, Flores-Garcia Y, et al. (2018) A human monoclonal antibody prevents malaria infection by targetting a new site of vulnerability in the parasite Nature Med doi:10.1038/nm.4512

Kiszewski A E (2011) Blocking Plasmodium falciparum malaria transmission with drugs: The gametocytocidal and sporontocidal properties of current and prospective antimalarials Pharmaceuticals (Basel) 4 44-68

Klonis N, Creek D J and Tilley L (2013) Iron and heme metabolism in Plasmodium falciparum and the mechanism of action of artemisinins Curr Opin Microbiol 16 722-727

Krafts K, Hempelmann E and Skorsha-Stania A (2012) From methylene blue to chloroquine: a brief review of the development of an antimalarial therapy Parasitol Res 111 $1-6$

Kremsner P G, Adegnika A A, Hounkpatin A B, Zinsou J F, Taylor T E, et al. (2016) Intramuscular artesunate for severe malaria in African children: a multicenter randomized controlled trial PLoS Med 13 e1001938

Krishna S, Bhandari S, Bharti P K, Basak S and Singh N (2017) A rare case of quadruple malaria infection from the highly malaria-endemic area of Bastar, Chhattisgarh, India PLoS Negl Trop Dis 11 e0005558

Krishna S, Ganapathu S, Ster I C, Saeed M E, Cowan M et al. (2014) A randomized, double-blind placebo-controlled pilot study of oral artesunate therapy for colorectal cancer Ebio Med 2 82-90

Kumar S, Banerjee S, Dwivedi S, Gupta M M, Verma R K et al. (1999) Registration of Jeevanraksha and Suraksha varieties of the antimalarial medicinal plant Artemisia annua JMed Arom Plant Sci 21 47-48

Kumar S, Gupta S K, Gupta M M, Verma R K, Jain D C et al. (2002) Method for maximization of artemisinin production by the plant Artemisia anuua US Patent no. 6,393,763B1

Kumar S, Gupta S K, Singh P, Bajpai P, Gupta M M et al. (2004) High yields of artemisinin by multi-harvest of Artemisia annua crops Indust Crops Prod 19 77-90

Kumar S, Kumari R and Pandey R (2015) New insight-guided approaches to detect, cure, prevent and eliminate malaria Protoplasma 251 717-753

Kumar S, Ram S, Verma D K, Dangesh A and Tomar V K S (2015) Public-private partnership towards rural development: a study of Artemisia annua in Uttar Pradesh Curr Sci 109 1237-1239

Kumar S and Srivastava S (2005) Establishment of artemisinin combination therapy as first line treatment for combating 
malaria: Artemisia annua cultivation in India needed for providing sustainable supply chain of artemisinin Curr Sci 89 1097-1102

Kung S H, Lund S, Murarka A, McPhee D and Paddon C J (2018) Approaches and recent developments for the commercial production of semi-synthetic artemisinin Front Plant Sci doi.org/10.3389/fpls.2018.00087

La Crue A N, Saenz F E, Cross RM, Udenze K O, Monastyrskyi A, Stein S, Mutka T S, Manetsch R and Kyle D E (2013) $4(1 \mathrm{H})$-quinolones with liver stage activity against Plasmodium berghei Antimicrob Agents Chemother $\mathbf{5 7}$ 417-424

Lachish T, Bar-Meir M, Eisenberg N and Schwartz E (2016) Effectiveness of twice a week prophylaxis with atovaquone-proguanil (Malarone??) in long-term travellers to West Africa $J$ Travel Med 23 pii: taw064

Lalloo D G, Shingadia D, Bell D J, Beeching N J, Whitty C J M and Chiodini P L (2016) UK malaria treatment guidelines 2016 J Infect 72 635-649

Laman M, Moore B R, Benjamin J M, Yadi G, Bona C, et al. (2014) Artemisinin-Naphthoquine versus ArtemetherLumefantrine for uncomplicated malaria in Papua New Guinean children: An open-label randomized trial PLoS Med 11 e1001773

Landier J, Parker D M, Thu A M, Carrara V I, Lwin K M, et al. (2016) The role of early detection and treatment in malaria elimination Malar J 15363

Laughlin J C (1994) Agricultural production of artemisinin-A review Trans R Soc Trop Med Hyg 88 21-22

Laughlin J C (2002) Post-harvest drying treatment effects on amtimalarial constituents of Artemiasia annua L. Acta Horticulturae 576 315-320

Leang R, Canavati S E, Khim N, Vestergaard L S, Borghini Fuhrer I, et al. (2016) Efficacy and safety of pyronaridineartesunate for treatment of uncomplicated Plasmodium falciparum malaria in western Cambodia Antimicrob Agents Chemother 60 3884-3890

Lee M S J, Maruyama K, Fujita Y, Konishi A, Lelliott P M et al. (2017) Plasmodium products persist in the bone marrow and promote chronic bone loss Sci Immunol 2 eaam8093

Lehane A M and Saliba K J (2008) Common dietary flavonoids inhibit the growth of the intraerythrocytic malaria parasite BMC Res Notes 126

Lelivre J, Almela M J, Lozano S, Miguel C, Franco V, et al. (2012) Activity of clinically relevant antimalarial drugs on Plasmodium falciparum mature gametocytes in an atp bioluminescence "transmission blocking" assay PLoS One 7 e35019
Li H, Wang W, Qu G, Li Y, Tao Y, et al. (2012) Effect of the in vivo activity of dihydroartemisinin against Schistosoma mansoni infection in mice Parasitol Res 110 1727-1732

Li H J, Wang W, Li Y Z, Qu G L, Xing Y T, et al. (2011) Effects of artemether, artesunate and dihydroartemisinin administered orally at multiple doses or combination in treatment of mice infected with Schistosoma japonicum Parasitol Res 109 515-519

Li J, Casteels T, Frogne T, Ingvorsen C, Honoré C, et al. (2017) Artemisinins target GABAA receptor signaling and impair á cell identity Cell 168 86-100.e15

Li Y, Wang S, Wang Y, Zhou C, Chen G, et al. (2013) Inhibitory effect of the antimalarial agent artesunate on collageninduced arthritis in rats through nuclear factor kappa B and mitogen-activated protein kinase signaling pathway Transl Res 161 89-98

Liu K C S C, Yang S L, Roberts M F, Elford B C and Phillipson J D (1992) Antimalarial activity of Artemisia annua flavonoids from whole plants and cell cultures Plant Cell Rep 11 637-640

Liu K C S C, Yang S L, Roberts M F, Elford B C and Phillipson J D (1999) The contribution of flavonoids to the antimalarial activity of Artemisia annua Planta Medica 55 654-655

Livezey J, Oliver T and Cantilena L (2016) Prolonged neuropsychiatric symptoms in a military service member exposed to mefloquine Drug Saf - Case Reports 37

Loo C S N, Lam N S K, Yu D, Su X zhuan and Lu F (2017) Artemisinin and its derivatives in treating protozoan infections beyond malaria Pharmacol Res 117 192-217

Lu F, Culleton R, Zhang M, Ramaprasad A and Von Seidlein L (2017) Emergence of Indigenous Artemisinin-Resistant Plasmodium falciparum in Africa N Engl J Med 376 991993

Luo A, Cai Z, Jing Y and Shen J (2009) Artemisinin content determination and AFLP analysis of Artemisia grown in Chongqing Mol Plant Breed 7 1144-1148

Malaria parasites. www.cdc.gov/malaria/about/biology/ parasites.htm

Maitlaud K, Nadel S, Pollard A J, Williams T N, Newton C R and Levin M (2006) Management of severe malaria in children: proposed guidelines for the United Kingdom BMJ 331 337-343

Magalhaes P, Dupont I, Hendrick X A, Joly A, Raas T et al. (2012) Anti-inflammatory effect and modulation of cytochrome P450 activities by Artemisia annua tea infusions in human intestinal caco-2 cells Food Chem 134 864-871 
Maiga H, Lasry I, Diarra M, Sagara J, Bamadio A, et al. (2016) Seasonal malaria chemoprevention with sulphadoxinepyrimethamine and amodiaquine selects DHER-DHPS quintuple genotype in Mali PLoS One 11 e0162718

Malhotra K, Subramaniyan M, Rawat K, Kalamuddin M, Qureshi M I, et al. (2016) Compartmentalized metabolic engineering for artemisinin biosynthesis and effective malaria treatment by oral delivery of plant cells Mol Plant 9 1464-1477

Malik A, Kushnoor A, Saini V, Singhal S, Kumar S and Yadav Y C (2011) In vitro antioxidant properties of scopoletin JChem Pharm Res 3 659-665

Marrelli M T and Brotto M (2016) The effect of malaria and anti-malarial drugs on skeletal and cardiac muscles Malar $J$ 15524

Masanja I M, Selemani M, Khatib R A, Amuri B, Kuepfer I, et al. (2013) Correct dosing of artemether-lumefantrine for management of uncomplicated malaria in rural Tanzania: do facility and patient characteristics matter? Malar $J \mathbf{1 2}$ 446

Mathur A K and Kumar S (1996) Micropropagation of Artemisia annua via the inflorescence $J$ Herbs Spices andMed Plants 4 61-71

Mayxay M, Pukrittayakamee S, Newton P N and White N J (2004) Mixed-species malaria infections in humans Trends Parasitol 20 233-240

Mazier D, Rénia L and Snounou G (2009) A pre-emptive strike against malaria's stealthy hepatic forms Nat Rev Drug Discov 8 854-864

Mbengue A, Bhattacharjee S, Pandharkar T, Liu H, Estiu G, et al. (2015) A molecular mechanism of artemisinin resistance in Plasmodium falciparum malaria Nature 520 683-687

McGready R, Tan S O, Ashley E A, Pimanpanarak M, Viladpainguen J, et al. (2008) A randomised controlled trial of artemether-lumefantrine versus artesunate for uncomplicated Plasmodium falciparum treatment in pregnancy PLoS Med 5 1699-1715

Medicine for malaria value. www.mmv.org/research.development/ artesunate-rd-portfolio

Menard D and Dondorp A (2017) Antimalarial drug resistance: a threat to malaria elimination Cold Spring Harb Perspect Med 7 1-24

Mesa L E, Lutgen P, Velez I D, Segura A M and Robledo S M (2015) Artemisia annua L., potential source of molecules with pharmacological activity in human diseases $\mathrm{Am} \mathrm{J}$ Phytomed Clinic Therapeutic 3 436-450

Mesa L E, Vasquez D, Lutgen P, Vélez I D, Restrepo A M, et al. (2017) In vitro and in vivo antileishmanial activity of
Artemisia annua L. leaf powder and its potential usefulness in the treatment of uncomplicated cutaneous leishmaniasis in humans Rev Soc Bras Med Trop 50 52-60

Milbroudt J, Auerochs S, Korn K and Marschall M (2009) Senstivity of human herpes virus 6 and other human herpes viruses to the broad-spectrum antiinfective drug artesunate Clin Virol 46 24-28

Milligan R, Daher A and Graves P M (2017) Primaquine at alternative dosing schedules for preventing relapse in people with Plasmodium vivax malaria Cochrane Database Syst Rev $\mathbf{2 0 1 7}$

Miotto O, Amato R, Ashley E A, MacInnis B, Almagro-Garcia J, et al. (2015) Genetic architecture of artemisinin-resistant Plasmodium falciparum Nat Genet 47 226-234

Mishina Y V, Krishna S, Haynes R K and Meade J C (2007) Artemisinins inhibit Trypanosoma cruzi and Trypanosoma brucei rhodesiense in vitro growth Antimicrob Agents Chemother 51 1852-1854

Mishra N (2014) Declining efficacy of artesunate plus sulfadoxinepyrimethamine in northeastern India Malaria $J 13284$

Misra H, Mehta D, Mehta B K and Jain D C (2014) Extraction of artemisinin , an active antimalarial phytopharmaceutical from dried leaves of Artemisia annua L., using microwaves and a validated HPTLC-visible method for its quantitative determination Hindawi 2014 1-11

Molina-Cruz A, Zilversmit M M, Neafsey D E, Hartl D L and Barillas-Mury C (2016) Mosquito vectors and the globalization of Plasmodium falciparum malaria Annu Rev Genet 50 447-465

Mombo-Ngoma G, Remppis J, Sievers M, Manego R J, Endamne L, Kabuwende L, et al. (2017) Efficacy and safety of fosmidomycin-piperaquine therapy for uncomplicated falciparum malaria- a single arm, age-de-escalation proof of concept studies in Gibbon Clin Infect Dis doi:10.1093/ $\mathrm{cid} / \mathrm{cia} 1122$

Mondal A and Chatterji U (2015) Artemisinin represses telomerase subunits and induces apoptosis in HPV-39 infected human cervical cancer cells J Cell Biochem 116 1968-1981

Mordmüller B, Surat G, Lagler H, Chakravarty S, Ishizuka A S, et al. (2017) Sterile protection against human malaria by chemoattenuated PfSPZ vaccine Nature 542 445-449

Mugittu K, Abdulla S, Falk N, Masanja H, Felger I, et al. (2005) Efficacy of sulfadoxine-pyrimethamine in Tanzania after two years as first-line drug for uncomplicated malaria: assessment protocol and implication for treatment policy strategies Malar J4 55

Muthamilselvan T, Kuo T F, Wu Y C and Yang W C (2016) 
Herbal remedies for coccidiosis control: A review of plants, compounds, and anticoccidial actions Evid Based Complement Alternat Med 20162657981

Mutiso J M, Macharia J C, Barasa M, Taracha E, Bourdichon A $\mathrm{J}$ and Gicheru M M (2011) In vitro and in vivo antileishmanial efficacy of a combination therapy of diminazene and artesunate against Leishmania donovani in BALB/c mice Rev Inst Med Trop Sao Paulo 53 129-132

Mwanza S, Nambozi M, Chileshe J, Joshi S, Malunga P, Kabuya J-B, Hachizovu S, et al. (2017) Chloroquine-sensitive Plasmodium falciparum in a high burden malaria area after over a decade of its withdrawl as first-line antimalarial medicine: Case of Nchelenge District BMJ Global Health 2 A 17

Naing C, Whittaker M A, Nyunt Wai V and Mak J W (2014) Is Plasmodium vivax malaria a severe malaria?: A systematic review and meta-analysis PLoS Negl Trop Dis 8 e3071

Nair A, Abrahamsson B, Barends D M, Groot D W, Kopp S, et al. (2012) Biowaiver monographs for immediate-release solid oral dosage forms: Primaquine phosphate $J$ Pharm Sci 101 936-945

Nasamu A S, , Glushakova S, Russo I, Vaupel B, Oksman A, Kim A S, Fremont D H, Tolia N, et al. (2017) Plasmepsins IX and $\mathrm{X}$ are essential and druggable mediators of malaria parasite egress and invasion Science 38 518-522

Newton P N, Angus B J, Chierakul W, Dondorp A, Ruangveerayuth R, et al. (2003) Randomized comparison of artesunate and quinine in the treatment of severe falciparum malaria Clin Infect Dis 37 7-16

Nsobya S L, Kiggundu M, Nanyunja S, Joloba M, Greenhouse B and Rosenthal P J (2010) In vitro sensitivities of Plasmodium falciparum to different antimalarial drugs in Uganda Antimicrob Agents Chemother 54 1200-1206

Nyunt M H, Han J-H, Wang B, Aye K M, Aye K H, et al. (2017) Clinical and molecular surveillance of drug resistant vivax malaria in Myanmar (2009-2016) Malar J 16117

Obonyo C O and Juma E A (2012) Clindamycin plus quinine for treating uncomplicated falciparum malaria: a systematic review and meta-analysis Malar $J \mathbf{1 1} 2$

Oluyomi S A, Justine T E and Faoziyat S (2009) Depletion of parasitaemia by halofantrine hydrochloride and artemether in rats infected with African trypanosomes Afr J Pharmacy and Pharmacol 3 432-438

Onimus M, Carteron S and Lutgen P (2013) The surprising efficiency of Artemisia annua powder capsules Med Aromat Plants 2125

Osei-Akoto A, Orton L C, Owusu-Oforis (2009) Atovaquone- proguanil for treating uncomplicated malaria Cochrane Rev John Wiley and Sons

Paddon C J and Keasling J D (2014) Semi-synthetic artemisinin: a model for the use of synthetic biology in pharmaceutical development Nat Rev Microbiol 12 355-367

Paeshuyse J, Coelmont L, Vliegen I, hemel J Van, Vandenkerckhove J, et al. (2006) Hemin potentiates the anti-hepatitis $\mathrm{C}$ virus activity of the antimalarial drug artemisinin Biochem Biophys Res Commun 348 139-144

Pain A, Böhme U, Berry A E, Mungall K, Finn R D, et al. (2008) The genome of the simian and human malaria parasite Plasmodium knowlesi Nature 455 799-803

Paloque L, Ramadani A P, Mercereau-Puijalon O, Augereau J-M and Benoit-Vical F (2016) Plasmodium falciparum: multifaceted resistance to artemisinins Malar J 15149

Paul S, Khanuja S P S, Shasany A K, Gupta M M, Darokar M P, et al. (2010) Enhancement of artemisinin content through four cycles of recurrent selection with relation to heritability, correlation and molecular marker in Artemisia annua L. Planta Med 76 1468-1472

Paul S, Gupta M M and Khanuja S P S (2012) Maintaining the artemisinin content through direct and indirect in vitro regeneration and their assessment of variation with the field from mother plants of Artemisia annua L. Nat Prod Bioprospect 2 194-199

Peatey C L, Leroy D, Gardiner D L and Trenholme K R (2012) Anti-malarial drugs: how effective are they against Plasmodium falciparum gametocytes? Malar J 1134

Pekyi D, Ampromfi A A, Tinto H, Traoré-Coulibaly M, Tahita M C, et al. (2016) Four artemisinin-based treatments in African pregnant women with malaria Malawi Med J 28 139-149

Pennings P S and Hermisson J (2006) Soft sweeps II - Molecular population genetics of adaptation from recurrent mutation or migration Mol Biol Evol 23 1076-1084

Phuc B Q, Rasmussen C, Duong T, Dong L, Loi M, Ménard D, et al. (2017) Treatment failure of dihydroartemisinin/ piperaquine for Plasmodium falciparum malaria, Vietnam Emerg Infect Dis 23 715-717

Pinato D J and Stebbing J (2015) Artemisia: A divine dart against cancer? The Lancet Oncology 16 759-760

Plucinski M M, Talundzic E, Morton L, Dimbu P R, Macaia AP, et al. (2015) Reply to "no robust evidence of lumefantrine resistance" Antimicrob Agents Chemoether 59 5867-5868

Pop I A, Oroian I, Lobontiu I and Friss Z (2017) Artemisia annua L. culture technology in the climate of Transylvania Procedia Eng 181 433-438 
Price R N, von Seidlein L, Valecha N, Nosten F, Baird J K and White N J (2014) Global extent of chloroquine-resistant Plasmodium vivax: A systematic review and meta-analysis Lancet Infect Dis 14 982-991

Rai P, Sharma D, Soni R, Khatoon N, Sharma B and Bhatt T K (2017) Plasmodium falciparum apicoplast and its transcriptional regulation through calcium signaling $L$ Microbiol 55 231-236

Rajgor D D, Gogtay N J, Kadam V S, Kocharekar M M, Parulekar M S, et al. (2014) Antirelapse efficacy of various primaquine regimens for Plasmodium vivax Malar Res Treat 2014347018

Ram M, Gupta M M, Dwivedi S and Kumar S (1997) Effect of plant density on the yields of artemisinin and essential oil in Artemisia annua cropped under low input cost management in North-Central India Planta Med 63 372374

RCOG=Royal College of Obstetricians and Gynaecologists (2010) The diagnosis and treatment of malaria in pregnancy Report no. : Green - top Guideline no. 54b

Rieckmann K H, McNamara J V, Frischer H, Stockert T A, Carson P E and Powell R D (1968) Gametocytocidal and sporontocidal effects of primaquine and of sulfadiazine with pyrimethamine in a chloroquine-resistant strain of Plasmodium falciparum Bull World Health Organ 38 625632

Rijken M J, McGready R, Phyo A P, Lindegardh N, Tarning J, Laochan N, Than H H, Mu O, Win A K, Singhasivanon P, White N and Nosten F (2011) Pharmacokinetics of dihydroartemisinin and piperaquine in pregnant and nonpregnant women with uncomplicated falciparum malaria Antimicrob Agents Chemother 55 5500-5506

Rodríguez E, Carman N J, Vander Velde G, McReynolds J H, Mabry T J, et al. (1972) Methoxylated flavonoids from Artemisia Phytochemistry 11 3509-3514

Romero M R, Efferth T, Serrano M A, Castaño B, MacIas R I R, et al. (2005) Effect of artemisinin/artesunate as inhibitors of hepatitis B virus production in an "in vitro" replicative system Antiviral Res 68 75-83

Rossi G, De Smet M, Khim N, Kindermans J M and Menard D (2017) Emergence of Plasmodium falciparum triple mutant in Cambodia Lancet Infect Dis 171233

Rottmann M, McNamara C, Yeung B K S, Lee M C S, Zou B, et al. (2010) Spiroindolones, a potent compound class for the treatment of malaria Science 329 1175-1180

Ruiz Sanchez F, Ruiz-Sanchez A and Naranjo Grande I (1956) The treatment of malaria with tetracycline Antibiotic Med 3 193-196
Rutledge G G, Böhme U, Sanders M, Reid A J, Cotton J A, et al. (2017) Plasmodium malariae and P. ovale genomes provide insights into malaria parasite evolution Nature 542 101104

Rutledge G G, Marr I, Huang G K L, Auburn S, Marfurt J, et al. (2017) Genomic characterization of recrudescent Plasmodium malariae after treatment with artemether/ lumefantrine Emerg Infect Dis 23 1300-1307

Sa J M, Twu O, Hayton K, Reyes S, Fay M P, et al. (2009) Geographic patterns of Plasmodium falciparum drug resistance distinguished by differential responses to amodiaquine and chloroquine Proc Natl Acad Sci USA 106 18883-18889

Sannella A R, Messori L, Casini A, Vincieri F F, et al. (2007) Modulation of the in vitro antimalarial effects of artemisinin by selected flavonoids and by reducing agents Planta Medica 73865

Sarciron M E, Saccharin C, Petavy A F and Peyron F (2000) Effects of artesunate, dihydroartemisinin, and an artesunate-dihydroartemisinin combination against Toxoplasma gondii Am J Trop Med Hyg 62 73-76

Saunders D L, Chaorattanakawee S, Gosi P, Lanteri C, Somethy $S$, et al. (2016) Atovaquone-proguanil remains a potential stopgap therapy for multidrug-resistant Plasmodium falciparum in areas along the Thai-cambodian border Antimicrob Agents Chemother 60 1896-1898

Schreiber A, Härter G, Schubert A, Bunjes D, Mertens T and Michel D (2009) Antiviral treatment of cytomegalovirus infection and resistant strains Expert Opin Pharmacother 10 191-209

Sen R, Bandyopadhyay S, Dutta A, Mandal G, Ganguly S, et al. (2007) Artemisinin triggers induction of cell-cycle arrest and apoptosis in Leishmania donovani promastigotes $J$ Med Microbiol 56 1213-1218

Sen R, Ganguly S, Saha P and Chatterjee M (2010) Efficacy of artemisinin in experimental visceral leishmaniasis Int $J$ Antimicrob Agents 36 43-49

Sergent T, Dupont I, Van Der Heiden E, Scippo M L, Pussemier L, et al. (2009) CYP1A1 and CYP3A4 modulation by dietary flavonoids in human intestinal Caco-2 cells Toxicol Lett 191 216-222

Shanks G D, Edstein M D and Jacobus D (2015) Evolution from double to triple- antimalarial drug combinations Trans Royal Soc Trop Med Hyg 109 182-188

Shen Q, Zhang L, Liao Z, Wang S, et al. (2018) The genome of Artemisia annua provides insight into the evolution of Asteraceae family and artemisinin biosynthesis Mol Plant doi.org/10.1016/j.molp.2018.03.015 
Shapira M Y, Resnick I B, Chou S, Neumann A U, Lurain N S, et al. (2008) Artesunate as a potent antiviral agent in a patient with late drug resistant cytomegalovirus infection after hematopoietic stem cell transplantation Clin Infect Dis $\mathbf{4 6}$ 1455-1457

Sharma V P, Dev V and Phookan S (2015) Neglected Plasmodium vivax malaria in northeastern States of India Indian JMed Res 141 546-555

Sharma Y D (2005) Genetic alteration in drug resistance markers of Plasmodium falciparum Indian J Med Res 121 13-22

Sibley C H, Hyde J E, Sims P F, Plowe C V, Kublin J G, et al. (2001) Pyrimethamine-sulfadoxine resistance in Plasmodium falciparum: what next? Trends Parasitol 17 582-588

Sidhu A B S, Uhlemann A, Valderramos S G, Valderramos J, Krishna S and Fidock D A (2006) Decreasing $p f m d r l$ copy number in Plasmodium falciparum malaria heightens susceptibility to mefloquine, lumefantrine, halofantrine, quinine, and artemisinin J Infect Dis 194 528-535

Sidhu AB S, Verdier-Pinard D and Fidock D A (2002) Chloroquine resistance in Plasmodium falciparum malaria parasites conferred by pfcrt mutations Science 298 210-213

Silvestrini F, Alano P and Williams J L (2000) Commitment to the production of male and female gametocytes in the human malaria parasite Plasmodium falciparum Parasitology 121 S0031182099006691

Simonnet X, Quennoz M and Carlen C (2008) New Artemisia annua hybrids with high artemisinin content Acta Hortic $769371-373$

Sinclair D, Zani B, Donegan S, Olliaro P and Garner P (2009) Artemisinin-based combination therapy for treating uncomplicated malaria Cochrane database Syst Rev CD007483

Singh B and Daneshvar C (2013) Human infections and detection of Plasmodium knowlesi Clin Microbiol Rev 26 165-184

Sinka M E, Bangs M J, Manguin S, Rubio-Palis Y, Chareonviriyaphap T, et al. (2012) A global map of dominant malaria vectors Parasit Vectors 569

Sirima S B, Ogutu B, Lusingu J P A, Mtoro A, Mrango Z, et al. (2016) Comparison of artesunate-mefloquine and artemether-lumefantrine fixed-dose combinations for treatment of uncomplicated Plasmodium falciparum malaria in children younger than 5 years in sub Sahara Africa: a randomized, multicentre, phase 4 trial Lancet Infect Dis 16 1123-1133

Sissoko M S, Healy S A, Katile A, Omaswa F, Zaidi I, et al. (2017) Safety and efficacy of PfSPZ vaccine against
Plasmodium falciparum via direct venous inoculation in healthy malaria-exposed adults in Mali: A randomised, double-blind phase 1 trial Lancet Infect Dis 17 498-509

Slack R D, Mott B T, Woodard L E, Triphati A, Sullivan D, et al. (2012) Malaria-infected mice are completely cured by one $6 \mathrm{mg} / \mathrm{kg}$ oral dose of a new monomeric trioxane sulfide combined with mefloquine J Med Chem 55 291-296

Sluydts V, Durnez L, Heng S, Gryseels C, Canier L, et al. (2016) Efficacy of topical mosquito repellent (picaridin) plus longlasting insecticidal nets versus long-lasting insecticidal nets alone for control of malaria: a cluster randomised controlled trial Lancet Infect Dis 16 1169-1177

Sonden K, Wyss K, Jovel I, Vieira da Silva A, Pohanka A, et al. (2017) High rate of treatment failures in nonimmune travelers treated with artemether-lumefantrine for uncomplicated Plasmodium falciparum malaria in Sweden: retrospective comparative analysis of effectiveness and case series Clin Infect Dis 64 199-206

Song Y, Lee S J, Jang S H, Kim T H, Kim H D, et al. (2017) Annual wormwood leaf inhibits the adipogenesis of 3T3L1 and obesity in high-fat diet-induced obese rats Nutrients 9 pii: E554

Srivastava I K and Vaidya A B (1999) A mechanism for the synergistic antimalarial action of atovaquone and proguanil Antimicrob Agents Chemother 43 1334-1339

St. Laurent B, Miller B, Burton T A, Amaratunga C, Men S, et al. (2015) Artemisinin-resistant Plasmodium falciparum clinical isolates can infect diverse mosquito vectors of Southeast Asia and Africa Nat Commun 68614

Staines H M, Burrow R, Teo B H, Chis Ster I, Kremsner P G and Krishna S (2017) Clinical implications of Plasmodium resistance to atovaquone/proguanil: A systematic review and meta-analysis J Antimicrob Chemother doi: 10.1093/ $\mathrm{jac} / \mathrm{dkx} 431$

Straimer J, Gnadig N F, Witkowski B, Amaratunga C, Duru V, et al. (2015) K13-propeller mutations confer artemisinin resistance in Plasmodium falciparum clinical isolates Science (80-.) 347 428-431

Suberu J O, Gorka A P, Jacobs L, Roepe P D, Sullivan N, et al. (2013) Anti-plasmodial polyvalent interactions in Artemisia annua L. aqueous extract - Possible synergistic and resistance mechanisms PLoS One $\mathbf{8}$

Sullivan D J, Matile H, Ridley R G and Goldberg D E (1998) A common mechanism for blockade of heme polymerization by antimalarial quinolines J Biol Chem 273 31103-31107

Sutherland C J (2016) Persistent Parasitism: the adaptive biology of malariae and ovale malaria Trends Parasitol 32 808-819 
Sutherland C J, Lansdell P, Sanders M, Muwanguzi J, van Schalkwyk D A, et al. (2017) Pfk13-independent treatment failure in four imported cases of Plasmodium falciparum malaria given artemether-lumefantrine in the UK Antimicrob Agents Chemother AAC.02382-16

Svensson U S and Ashton M (1999) Identification of the human cytochrome $\mathrm{P} 450$ enzymes involved in the in vitro metabolism of artemisinin Br J Clin Pharmacol 48 528535

Tainchum K, Kongmee M, Manguin S, Bangs M J and Chareonviriyaphap T (2015) Anopheles species diversity and distribution of the malaria vectors of Thailand Trends Parasitol 31 109-119

Takala-Harrison S, Jacob C G, Arze C, Cummings M P, Silva J C, et al. (2015) Independent emergence of artemisinin resistance mutations among Plasmodium falciparum in Southeast Asia J Infect Dis 211 670-679

Tan K R, Magill A J, Parise M E and Arguin P M (2011) Doxycycline for malaria chemoprophylaxis and treatment: Report from the CDC expert meeting on malaria chemoprophylaxis Am J Trop Med Hyg 84 517-531

Tanaka T Q and Williamson K C (2011)A malaria gametocytocidal assay using oxidoreduction indicator, alamarBlue $\mathrm{Mol}$ Biochem Parasitol 177 160-163

Thanh N V, Thuy-Nhien N, Tuyen N T K, Tong N T, Nha-Ca N $\mathrm{T}$, et al. (2017) Rapid decline in the susceptibility of Plasmodium falciparum to dihydroartemisininpiperaquine in the south of Vietnam Malar J 1627

Tilley L, Straimer J, Gnädig N F, Ralph S A and Fidock D A (2016) Artemisinin action and resistance in Plasmodium falciparum Trends Parasitol 32 682-696

Tine R C, Sylla K, Faye B T, Poirot E, Fall F B, et al. (2017) safety and efficacy of adding a single low dose of primaquine to the treatment of adult patients with Plasmodium falciparum malaria in senegal, to reduce gametocyte carriage: A Randomized controlled trial Clin Infect Dis 65 535-543

Towler M J and Weathers P J (2015) Variations in key artemisinic and other metabolites throughout plant development in Artemisia annua L. for potential therapeutic use Ind Crops Prod 67 185-191

Utzinger J, N'Goran E K, N'Dri A, Lengeler C, Shuhua X and Tanner M (2000) Oral artemether for prevention of Schistosoma mansoni infection: Randomised controlled trial Lancet 355 1320-1325

Vaidya A B and Mather M W (2009) Mitochondrial evolution and functions in malaria parasites Annu Rev Microbiol 63 249-267
Van Hensbroek M B, Onyiorah E, Jaffar S, Schneider G, Palmer A, et al. (1996) A trial of artemether or quinine in children with cerebral malaria $N$ Engl J Med 335 69-75

Van Zyl R L, Seatlholo S T, Van Vuuren S F and Viljoen A M (2006) The biological activities of 20 nature identical essential oil constituents J Essent Oil Res 18 129-133

Vandewynckel Y P, Laukens D, Geerts A, Vanhove C, Descamps B, et al. (2014) Therapeutic effects of artesunate in hepatocellular carcinoma: repurposing an ancient antimalarial agent Eur J Gastroenterol Hepatol 26 861870

Verlinden B K, Louw A and Birkholtz L M (2016) Resisting resistance: is there a solution for malaria? Expert Opin Drug Discov 11 395-406

Visser B J, Wieten R W, Kroon D, Nagel I M, Bélard S, et al. (2014) Efficacy and safety of artemisinin combination therapy (ACT) for non-falciparum malaria: A systematic review Malar J 13463

Wall R and Watson J (2017) Artemisia annua L. GRAS research FDA_Artemisia_annua_GRAS_IQP

Wang X Q, Liu H L, Wang G B, Wu PF, Yan T, et al. (2011) Effect of artesunate on endotoxin-induced uveitis in rats Investig Ophthalmol Vis Sci 52 916-919

Want M Y, Islammudin M, Chouhan G, Ozbak H A, Hemeg H A, et al. (2017) Nanoliposomal artemisinin for the treatment of murine visceral leishmaniasis Int J Nanomedicine 12 2189-2204

Weathers P, Reed K, Hassanali A, Lutgen P and Engeu P O (2014c) Whole plant approaches to therapeutic use of Artemisia annua L. (Asteraceae) In: Aftab T, Ferreira J, Khan M., Naeem M. (eds) Artemisia annua Pharmacology and Biotechnology Springer, Berlin, Heidelberg

Weathers P J, Arsenault P R, Covello P S, McMickle A, Teoh K $\mathrm{H}$ and Reed D W (2011) Artemisinin production in Artemisia annua: Studies in planta and results of a novel delivery method for treating malaria and other neglected diseases Phytochem Rev 10 173-183

Weathers P J, Cambra H M, Desrosiers M R, Rassias D and Towler M J (2017) Artemisinin the noble molecule: From plant to patient Studies Nat Prod Chem 52 193-229

Weathers P J, Elfawal M A, Towler M J, Acquaah-Mensah G K and Rich S M (2014b) Pharmacokinetics of artemisinin delivered by oral consumption of Artemisia annua dried leaves in healthy vs. Plasmodium chabaudi-infected mice J Ethnopharmacol 153 732-736

Weathers P J, Jordan N J, Lasin P and Towler M J (2014d) Simulated digestion of dried leaves of Artemisia annua 
consumed as a treatment (pACT) for malaria $J$ Ethnopharmacol 151 858-863

Weathers P J and Towler M J (2014) Changes in key constituents of clonally propagated Artemisia annua L. during preparation of compressed leaf tablets for possible therapeutic use Ind Crops Prod 62 173-178

Weathers P J, Towler M, Hassanali A, Lutgen P and Engeu P O (2014a) Dried-leaf Artemisia annua: A practical malaria therapeutic for developing countries? World J Pharmacol 3 39-55

Whirl-Carrillo M, McDonagh E M, Hebert J M, Gong L, Sangkuhl $\mathrm{K}$, et al. (2012) Pharmacogenomics knowledge for personalized medicine Clin Pharmacol Ther 92 414-417

White N J (2005) Artesunate versus quinine for treatment of severe falciparum malaria: A randomised trial Lancet $\mathbf{3 6 6}$ $717-725$

White N J (2013) Primaquine to prevent transmission of falciparum malaria Lancet Infect Dis 13 175-181

White N J (2014) Malaria: A molecular marker of artemisinin resistance Lancet 383 1439-1440

White N J (2016) Can new treatment developments combat resistance in malaria? Expert Opin Pharmacother 13031307

White N J (2017) Malaria parasite clearance Malar J 1688

White N J, Ashley E A, Recht J, Delves M J, Ruecker A, et al. (2014) Assessment of therapeutic responses to gametocytocidal drugs in Plasmodium falciparum malaria Malar J13 483

White N J, Looareesuwan S, Warrell D A, Warrell M J, Chanthavanich P, et al. (1983) Quinine loading dose in cerebral malaria Am J Trop Med Hyg 32 1-5

WHO (2015a) Guidelines for treatment of malaria-3 ${ }^{\text {rd }}$ edition www.who.int/malaria/publications/atoz/978941548528/ enl technical brief. www//apps.who.int/iris/bitshean/ 10665/181162/1/9789241509244_eng.pdf

WHO Artemisinin and artemisinin based combination therapy resistance. WHO-HTM-GMP-2017.9-eng.pdf

WHO: Severe malaria. Trop Med Int Health 2014; 19 (Supplement 1)

WHO (2012) Effectiveness of non-pharmaceutical forms of Artemisia annua L. against malaria. http:/www.who.int/ malaria/position_statement_herbal_remedy_ artemisia_annua 1.pdf

Witkowski B, Duru V, Khim N, Ross L S, Saintpierre B, et al. (2017) A surrogate marker of piperaquine-resistant Plasmodium falciparum malaria: a phenotype-genotype association study Lancet Infect Dis 17 174-183

Wootton J C, Feng X, Ferdig M T, Cooper R A, Mu J, et al. (2002) Genetic diversity and chloroquine selective sweeps in Plasmodium falciparum Nature 418 320-323

Wu X, Zhang W, Shi X, An P, Sun W and Wang Z (2010) Therapeutic effect of artemisinin on lupus nephritis mice and its mechanisms Acta Biochim Biophys Sin (Shanghai) 42 916-923

WWARN Gametocyte Study Group (2016) Gametocyte carriage in uncomplicated Plasmodium falciparum malaria following treatment with artemisinin combination therapy: a systematic review and meta-analysis of individual patient data $B M C$ Med 1479

Xiao L, Yang C, Patterson P S, Udhayakumar V and Lal A A (1996) Sulfated polyanions inhibit invasion of erythrocytes by plasmodial merozoites and cytoadherence of endothelial cells to parasitized erythrocytes Infect Immun 64 13731378

Yamachika E, Habte T and Oda D (2004) Artemisinin: An alternative treatment for oral squamous cell carcinoma Anticancer Res 24 2153-2160

Yarnell E (2014) Artemisia annua (Sweet Annie), other Artemisia species, artemisinin, artemisinin derivatives, and malaria $J$ Restor Med 3 69-84

Yimer S and Sahu O (2016) Traditional medicines for treatment of African diseases by Artemisia annua Medic Sci Pub Health 4 22-32

York A (2017) Seasonal malaria chemoprevention in the Sahel Lancet Infect Dis 17588

Zani B, Gathu M, Donegan S, Olliaro P L and Sinclair D (2014a) Dihydroartemisinin-piperaquine for treating uncomplicated Plasmodium falciparum malaria Cochrane database Syst Rev CD010927

Zani B, Gathu M, Donegan S, Olliaro P L and Sinclair D (2014b) The Cochrane database of systematic reviews 1: CD010927 Dihydroartemisinin-piperaquine for treating uncomplicated Plasmodium falciparum malaria Cochrane Database Syst Rev CD010927

Zhang M, Wang C, Otto T D, Oberstaller J, et al. (2018) Uncovering the essential genes of the human malaria parasite Plasmodium falciparum by saturation mutagenesis Science 360 eaap 7847

Zhou X, Sun W-J, Wang W-M, Chen K, Zheng J-H, et al. (2013) Artesunate inhibits the growth of gastric cancer cells through the mechanism of promoting oncosis both in vitro and in vivo Anticancer Drugs 24 920-927. 